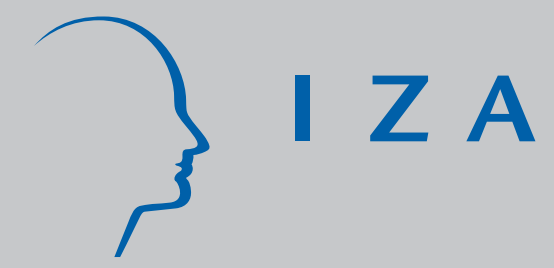

IZA DP No. 4119

Evaluating the Impact of Community-Based Health Interventions:

Evidence from Brazil's Family Health Program

Romero Rocha

Rodrigo R. Soares

April 2009 


\title{
Evaluating the Impact of Community-Based Health Interventions: Evidence from Brazil's Family Health Program
}

\author{
Romero Rocha \\ Pontifical Catholic University of Rio de Janeiro \\ Rodrigo R. Soares \\ Pontifical Catholic University of Rio de Janeiro, \\ NBER and IZA
}

Discussion Paper No. 4119

April 2009

IZA

P.O. Box 7240

53072 Bonn

Germany

Phone: +49-228-3894-0

Fax: +49-228-3894-180

E-mail: iza@iza.org

\begin{abstract}
Any opinions expressed here are those of the author(s) and not those of IZA. Research published in this series may include views on policy, but the institute itself takes no institutional policy positions.

The Institute for the Study of Labor (IZA) in Bonn is a local and virtual international research center and a place of communication between science, politics and business. IZA is an independent nonprofit organization supported by Deutsche Post Foundation. The center is associated with the University of Bonn and offers a stimulating research environment through its international network, workshops and conferences, data service, project support, research visits and doctoral program. IZA engages in (i) original and internationally competitive research in all fields of labor economics, (ii) development of policy concepts, and (iii) dissemination of research results and concepts to the interested public.
\end{abstract}

IZA Discussion Papers often represent preliminary work and are circulated to encourage discussion. Citation of such a paper should account for its provisional character. A revised version may be available directly from the author. 


\section{ABSTRACT}

\section{Evaluating the Impact of Community-Based Health Interventions: Evidence from Brazil's Family Health Program}

This paper analyzes the direct and indirect impacts of Brazil's Family Health Program. We estimate the effects of the program on mortality and on household behavior related to child labor and schooling, employment of adults, and fertility. We find consistent effects of the program on reductions in mortality throughout the age distribution, but mainly at earlier ages. Municipalities in the poorest regions of the country benefit particularly from the program. For these regions, implementation of the program is also robustly associated with increased labor supply of adults, reduced fertility, and increased schooling. Evidence suggests that the Family Health Program is a highly cost-effective tool for improving health in poor areas.

JEL Classification: I12, I18, J10, J13, J24, O54

Keywords: family health program, mortality, household behavior, impact evaluation, Brazil

Corresponding author:

Rodrigo R. Soares

Departamento de Economia

Pontifícia Universidade Católica do Rio de Janeiro

Rua Marquês de São Vicente, 225 - Gávea

22451-900 Rio de Janeiro, RJ

Brazil

E-mail: soares@econ.puc-rio.br

\footnotetext{
* The authors gratefully acknowledge financial support from the Global Development Network (GDN) and the Bill \& Melinda Gates Foundation, under the grant program "Promoting Innovative Programs from the Developing World: Towards Realizing the Health MDGs in Africa and Asia." Excellent research assistance was provided by Edson Severnini and Hamilton Kai. The authors also wish to thank Christoph M. Schmidt for numerous detailed comments and Berardo Augusto Nunan for help in obtaining the data and for clarifications regarding operational aspects of the Family Health Program. The paper benefited from suggestions from Angus Deaton, Shubhashis Gangopadhyay, Ernesto Schargrodsky, Jeffrey Smith, Lyn Squire, Ranjeeta Thomas, and seminar participants at the Harvard School of Public Health, IPEA - Rio, PUC - Rio, the 2008 AEA Meetings (New Orleans), the 2008 NBER Inter - American Seminar on Economics (Santiago, Chile), the $13^{\text {th }}$ LACEA Annual Meeting (Rio de Janeiro, Brazil, 2008), the $36^{\text {th }}$ ANPEC Annual Meeting (Salvador, Brazil, 2008), the 2008 IMF Methodology Workshop (Washington DC), and various GDN Workshops.
} 


\section{Introduction}

This paper analyzes the direct and indirect impacts of Brazil's Family Health Program. Direct impacts are related to the effects of the program on health outcomes. Indirect impacts refer to the effects of the program, through changes in health, on household behavior related to child labor and schooling, employment of adults, and fertility. We show that implementation of the program was associated with reductions in mortality throughout the age distribution, but particularly at early ages (before age 5). The response to the program seems stronger in municipalities in the poorest regions of the country and with worse initial conditions. In these same regions, the program was robustly associated with increased labor supply of adults, reduced fertility, and increased school enrollment.

The Family Health Program ("Programa Saúde da Família," from now on PSF) is a project from the Brazilian Ministry of Health. It targets prevention and provision of basic health through the use of professional health-care teams directly intervening at the family/community level. Each team is responsible for a predetermined number of families, located at a specific geographic area. The teams provide health counseling, prevention, orientation related to recovery, and advice for fighting frequent diseases and for overall health protection in the community. The supply of basic health care at the community level and the assignment of responsibility to the team of health professionals changed the traditional definition and form of health care provision in Brazil. This change shifted health care provision from a centralized model structured around public hospitals in main urban areas to a decentralized one, where the first point of contact between population and the public health system is shifted to local communities. This new approach potentially opens space for the inclusion of a large number of poor families, in one way or another, in the public health system.

Generally, this type of intervention has the potential of being extremely relevant for poor developing countries. This is an intervention that is relatively cheap and technologically simple, and that can be used to extend access to basic health care to a large fraction of the disadvantaged population. At the same time, the approach is supposed to lessen the pressure on the more traditional providers of public health (public hospitals, clinics, etc.). Community and family based approaches have been identified in the demographic literature as one of the key factors promoting improvements in health even under very poor economic conditions. Classical examples include the Indian state of Kerala, Jamaica and Costa Rica, where the use of 
community-level interventions as instruments to improve health education and to deliver services is believed to have led to major reductions in mortality under more or less stagnant economic conditions (Caldwell, 1986 and Riley, 2005). Different mechanisms have been suggested as driving forces behind the impact of this type of intervention: instruction of families about the main health risks and other potentially simple changes in health behavior; easy access to primary health care and its role in prevention and early detection of diseases; and engagement of the community in public campaigns related to immunization and fight against endemic conditions (see Caldwell, 1986, Riley, 2005 and 2007, and Soares, 2007b). Still, despite being widely regarded as a major tool in the fight for improved health, there is little sound econometric evidence on the efficacy of such community-based interventions. ${ }^{1}$ There is also no explicit cost-benefit analysis of the viability of implementation of this type of strategy in contexts different from those analyzed in the historical experiences mentioned above.

In parallel to the demographic literature, a recent line of both theoretical and empirical research in economics has suggested that improvements in health conditions may lead to important changes in household behavior related to labor supply, investments in human capital, and fertility (see, for example, Meltzer, 1992, Miguel and Kremer, 2004, Kalemli-Ozcan, 2002 and 2006, Soares, 2005, Bobonis, Miguel, Puri-Sharma, 2006, Bleakley and Lange, 2009, Lleras-Muney and Jayachandran, 2009, and Lorentzen, McMillan, and Wacziarg, 2008). As immediate impacts, better health increases physical strength and improves the performance of a series of biological mechanisms, from the fight against infections to the nourishing of fetuses in the womb. In particular, community based health interventions may give families access to technologies that were previously too expensive or unknown, such as birth control methods or rehydration therapy, directly changing household production technologies. In the long-run, these changes may increase the return to investments in human capital and attachment to the labor market, shifting the quantity-quality trade-off toward fewer and better educated children. From this perspective, improvements in health could also bring together increased schooling and reduced fertility.

\footnotetext{
${ }^{1}$ Fernández, Galiani, and Schargrodksy (2006) analyze the efficacy of targeting of a health program (PROMIN) focused at improving primary medical attention in Argentina. The program implemented health care centers in poor areas, similarly to the Family Health Program.
} 
The goal of this paper is therefore twofold. First, we use the recent experience of Brazil's Family Health Program to assess the effectiveness of community based health interventions as instruments for improvements in health conditions in less developed areas. Second, we evaluate whether the health improvements associated with the program also brought about the changes in household behavior predicted by economic theory and noticed in other contexts (such as in Miguel and Kremer, 2004, Bleakley and Lange, 2009, and Lleras-Muney Jayachandran, 2009).

As a case study, Brazil's PSF presents a series of advantages, partly derived from the fact that the program was implemented only very recently and was consistently expanded through time: i) there is reasonably detailed intervention data available at the municipality level almost since initial implementation; ii) municipality coverage expanded from zero to more than ninety percent in less than fifteen years, as part of an explicit effort from the central government; and iii) there are comparable datasets available in Brazil, which allow the analysis of different dimensions of potential impacts of the program. For these reasons, we are able to document and analyze the impact of the PSF in a level of detail and with a statistical care that was not possible in the more famous historical experiences of community based health interventions. In principle, the setup and the techniques involved in the program are adaptable to other developing countries. Also, the human and geographic heterogeneity within Brazil allow investigation of how the program performs under different circumstances and against different types of health conditions, and provides a good laboratory for the likely effectiveness of the strategy in other contexts.

We use municipality level mortality data (by age and cause of death) to analyze the health impact of the PSF, and its specific characteristics in terms of age groups and causes of death. By crossing municipality level data with the Brazilian National Household Survey (Pesquisa Nacional por Amostra de Domicílios, from now on PNAD), we analyze the impact of the program on labor supply, fertility, and school enrollment and child labor. We take advantage of the staggered process of implementation of the program since 1994 and use a difference-in-difference estimator to allow the effect of the program to be heterogeneous according to time of exposure. For the household data, we concentrate the analysis on the poorest regions of the country, where the health impacts of the PSF turn out to be strongest. 
Our results show that implementation of the Family Health Program was significantly associated with reductions in mortality before age 1 , between ages 1 and 4 , and between ages 15 and 59. Particularly, municipalities eight years into the program are estimated to experience a reduction of 5.4 per 1,000 in mortality before age 1 , as compared to municipalities not covered by the program. The estimated impacts are driven mostly by reductions in mortality due to perinatal period conditions, infectious diseases, endocrine and metabolic diseases, and respiratory diseases.

The PSF seems to be most effective in the North and Northeast regions of Brazil, and also in municipalities with a higher fraction of rural population, and lower coverage of public health infrastructure (access to treated water and sewerage system). In relation to changes in behavior that may be determined from improvements in health, our analysis concentrates on the two poorest regions of the country. We find that eight years of exposure to the program are associated with a 6.8 percentage point increase in the labor supply of adults between 18 and 55, a 4.5 percentage point increase in the school enrollment of children between 10 and 17, and a 4.6 percentage point reduction in the probability that women aged between 18 and 55 experience a birth over a given 21-month interval.

The remainder of the paper is structured as follows. Section 2 outlines a brief history of the Family Health Program and its organizational structure. Section 3 describes the various datasets used in our statistical analysis. Section 4 discusses our empirical strategy. Section 5 presents the results on the effects of the Family Health Program on mortality. Section 6 presents the results on individual behavior. Finally, section 7 concludes the paper.

\section{Overview and Brief History of the Family Health Program}

The Family Health Program is an ongoing project of the Unique System of Health ("Sistema Único de Saúde"), from the Brazilian Ministry of Health. Since its origins in the mid 1990s, the program has been constantly expanded, with the progressive adhesion of new municipalities. Particularly since the beginning of the 2000s, there has been an expressive growth in the number of municipalities covered. The consolidation of this strategy marks a shift in the provision of basic health care in Brazil, away from hospital and health clinics, and toward cheaper and supposedly more effective day-to-day preventive care. 
The PSF targets provision of basic health care through the use of professional teams placed inside the communities. The teams are composed by, at least, one family doctor, one nurse, one assistant nurse, and six health community agents. Some expanded teams also include one dentist, one assistant dentist, and one dental hygiene technician. Each team is responsible for following about 3,000 to 4,500 people, or 1,000 families of a pre-determined area. The actual work of the teams takes place in the basic health units and in the households. The key characteristics of the program identified by the Brazilian Ministry of Health are: i) to serve as an entry point into a hierarchical and regional system of health; ii) to have a definite territory and delimited population of responsibility of a specific health team, establishing liability (co-responsibility) for the health care of a certain population; iii) to intervene in the key risk factors at the community level; iv) to perform integral, permanent, and quality assistance; v) to promote education and health awareness activities; vi) to promote the organization of the community and to act as a link between different sectors, so that the community can exercise effective control of actions and health services and develop strategies for specific health interventions; and vii) to use information systems to monitor decisions and health outcomes (Secretaria de Políticas de Saúde - Departamento de Atenção Básica, 2000 and Brazilian Ministry of Health, 2006a). The yearly cost of maintaining a PSF team was estimated, in 2000, to be between $\mathrm{R} \$ 215,000$ and $\mathrm{R} \$ 340,000$, or between US\$109,610 and US\$173,400 (Fundação Getúlio Vargas and EPOS Health Consultants, 2001). Assuming team coverage of roughly 3500 individuals, this would correspond to a yearly cost between US\$ 31 and US\$ 50 per individual covered. $^{2}$

In reality, the main focuses of the program are on improvement of basic health practices, prevention, early detection, and coordination of large scale efforts. First, by following families through time on a recurrent basis, health care professionals can teach better practices and change habits, leading to better health management at home (through handling and preparation of foods, diet, cleanliness, strategies to deal with simple health conditions, etc). On itself, this should reduce the occurrence of simpler health conditions and improve the management of other types of diseases that may be endemic to certain areas. In addition, by interacting on a systematic basis with the same families, health care professionals are able to detect early symptoms that may require a more specific type of care. In these cases, families

\footnotetext{
${ }^{2}$ These cost estimates do not include the excess burden from the taxes raised to finance the program.
} 
are referred to hospitals or specialists. Finally, the network of PSF professionals, once established in a certain area, can be used to implement any type of health intervention that demands some degree of coordination across large areas or different agents (immunizations, campaigns against endemic conditions, etc).

The program is targeted at poor communities. The idea is that by placing teams inside a disadvantage area, basic health care can be extended to a group of people that in most cases had almost no access to public health. At the same time, simpler conditions can be dealt with in the community itself, lessening the pressure on public hospitals, which then would be left to deal with more serious medical conditions. In this context, the work of the teams is essential in the ongoing communication and exchange of experiences among public health care professionals and community health agents. Part of the advantage of having such a focused program implemented at the national level is precisely that the various experiences across different teams and areas can quickly lead to improved practices and better health outcomes at other communities, with successful strategies being diffused throughout the entire system.

The PSF is a federal program that is implemented at the municipality level. Implementation therefore requires coordination across different spheres of government. The institutional design of the program is such that, ideally, implementation would involve all three levels of government (municipality, state, and central government), but there are stories of programs implemented without support or interference of the state government. In simple terms, the program is a package designed by the Ministry of Health and implementation requires voluntary adhesion of a municipality administration, preferably with support from the state government. Officially, the responsibilities across the different spheres of government are defined in the following way (Brazilian Ministry of Health, 2006a):

$\rightarrow$ Federal Government: elaborate the basic health goals of national policy; co-finance the system of "basic health attention;" organize the formation of human resources in the area; propose mechanisms to program, control, regulate and evaluate the system of "basic health attention;" maintain the national database;

$\rightarrow$ State Government: follow the implementation and execution of the Family Health Program; regulate the inter-municipal relations; coordinate policies of human resources qualification in the state; co-finance the program; help in the execution of the strategies of the system of basic health attention; and 
$\rightarrow$ Municipality Government: define and implement the model of the Family Health Program; hire the labor for use in the program; maintain the management network of basic health units; co-finance the program; maintain the system of information; evaluate the performance of the basic health attention teams under its supervision.

The history of expansion of the program is portrayed in Figures 1 and 2. The program was expanded from a minor pilot program covering very few selected areas in 1994 to a nationwide large scale program in 2006. Today, the PSF is present in more than $90 \%$ of Brazilian municipalities and is estimated to cover more than 85 million people (Brazilian Ministry of Health, 2006b). Figure 2 shows that this expansion in municipality coverage was accompanied by a similar expansion in the number of active health teams, from 300 in 1994 to 26,500 in 2006. After an initial decline until the end of the 1990s, the average number of teams per municipality increased again to reach in 2006 a level very similar to that observed in 1994 (5.2 in the end of the period, against 5.5 in the beginning). The federal budget was concomitantly expanded, from $\mathrm{R} \$ 280$ million in 1998 to $R \$ 2,679$ million in 2005 (or from US\$ 233 million to US\$ 1,175 million).

The accelerated expansion of the PSF starting in 1998 was a result of an explicit effort on the part of the central government, associated with the intensification of federal support and the development of a more standardized "package." Figure 3 shows that this expansion was also associated with a homogenization of the distribution of the program across the various areas of the country.

In a sense, the federal nature of the program and the goal of the central government to expand it to virtually the entire country are, from an empirical perspective, convenient features of the Brazilian experience. Almost every municipality was eventually incorporated into the PSF, so eventual adhesion to the program does seem to have an exogenous dimension of variation. Still, as will be clear later on, the timing of adoption did depend on initial socioeconomic conditions, and this constitutes one of the main concerns of our empirical analysis.

The few empirical studies available on the PSF stem from the public health literature. Macinko, Guanais, and Marinho de Souza (2006) evaluate the impact of the program on infant mortality, using state level data (27 states). Their results show a significant impact on mortality, but the type of data and the econometric techniques used raise concerns in relation to identification. In addition, they do not analyze impacts by age and cause of death, nor potential 
socioeconomic spillovers of the program on household behavior. Macinko, Almeida, and Sá (2007) conduct a survey to assess the effect of the presence of the program on perceived subjective health. They show that the presence of the program in a given municipality is associated with better perceived health on the part of the population. ${ }^{3}$

The specific contribution of this paper is to use municipality level data to conduct an extensive analysis of the effects of the PSF on mortality by age group, cause of death, region, and initial mortality level. In addition, we evaluate whether presence of the program also induced changes in household behavior, along dimensions of labor supply of adults and children, school attendance, and fertility.

\section{Data}

We use data from several different sources in order to analyze the various potential impacts of the PSF. Data related to implementation of the program at the municipality level is available from the Brazilian Ministry of Health, through its Basic Attention Department ("Departamento de Atenção Básica"). These data provide the date of implementation in each municipality (starting from 1996).

Data on various dimensions of mortality at the municipality level are also available from the Brazilian Ministry of Health, through its integrated system of information (DATASUS). These data are used to evaluate the direct impact of the program on health outcomes. Though mortality data coverage in some of the poorest states in the country can be considered deficient (see Paes and Albuquerque, 1999), our econometric strategy - to be explained later on - controls for any systematic difference in levels of measured mortality across states in a given year, so that this concern should not affect the results.

Other municipality level data required as controls in the statistical analysis - such as public health policies, education infrastructure, and immunization - are obtained from the Ministry of Health, from the Brazilian Census Bureau ("Instituto Brasileiro de Geografia e Estatística"), from the Institute for Applied Economic Research ("Instituto de Pesquisa

\footnotetext{
${ }^{3}$ There are also studies describing the expansion of the Family Health Program and discussing informally the patterns of mortality reductions associated with the presence of the program, such as Brazilian Ministry of Health (2006b).
} 
Econômica Aplicada"), and from the National Institute of Research on Education ("Instituto Nacional de Pesquisa em Educação").

Assessments of the impact of the PSF on household and individual decisions require the use of micro-data from the Brazilian National Household Survey (PNAD). This dataset provides information at the household and individual level on a series of demographic and economic characteristics. In order to analyze the various dimensions discussed before, we use 10 rounds of the PNAD to create two datasets: one focused on adults, and another on children.

The period covered in our analysis is constrained by data availability. We do not have information on the very few municipalities covered by the program in 1994 and 1995, so we simply assume that coverage did not start until 1996. ${ }^{4}$ When we include our full set of controls, this leaves us with a sample spanning the period between 1995 and 2003. Table A.1 in the Appendix contains a description of the variables included in our analysis, as well as their sources and availability in terms of years of coverage.

Table 1 presents descriptive statistics for each year between 1993 and 2004, for both municipalities covered and not covered by the PSF. It becomes clear from the table that the program was first implemented in municipalities that were poorer and had worse health conditions. This is one of the concerns that guide our empirical strategy. It is also clear the declining trend in mortality and increasing income per capita, both in municipalities covered and not covered by the PSF. ${ }^{5}$

\section{Empirical Strategy}

\subsection{Health Impacts}

In the analysis of the health impacts of the program, our unit of observation is a municipality at a point in time. Our main approach is based on the difference-in-difference estimator. An important point is that the effect of the program may vary with the time of exposure, both because of logistical considerations in the initial phases of implementation and because some of the health impacts may be felt only after some time lag. Therefore, we allow

\footnotetext{
${ }^{4}$ In these cases, we ignore the small coverage that already existed in 1994 (1.1\%) and 1995 (3\%). In reality, most of our estimations cover only the period between 1995 and 2003.

${ }^{5}$ Since municipality GDP is not available before 1999, we do not include this variable in our regressions. The exchange rate R\$/US\$ varied between 1.84 and 2.72 in the period under analysis, so the GDP per capita numbers shown in the table vary between US\$ 2,899 and U\$ 4,274.
} 
for heterogeneous effects of the PSF according to the number of years a municipality has spent in the program.

In this context, there are two main econometric concerns in the evaluation of public policy interventions. First, adoption of the PSF may depend on a municipality's health conditions or performance and, therefore, be an endogenous variable. The fact that the PSF was consistently expanded as part of an explicit effort of the central government, until it included almost all municipalities in Brazil, suggests that eventual adoption did not suffer so much from this endogeneity problem. Still, endogeneity may be a serious concern in relation to the specific timing of adoption in a given municipality. As long as adoption is correlated with some pre-existing condition, such as initial mortality, the municipality fixed-effects present in a difference-in-difference approach take care of the problem. More worrisome are the following possibilities: the timing of adoption is related to some dynamic characteristic of the dependent variable, such as when municipalities subject to particularly negative health shocks are more likely to receive the program; or initial conditions are associated with a specific dynamic evolution of the dependent variable, such as when there is tendency toward convergence, so that initially worse-off municipalities naturally catch-up to better-off ones.

Due to a large number of municipalities (almost 5,000 in most specifications), computational limitations and reduced degrees of freedom prevent us from using municipalityspecific linear trends. Therefore, our specification includes state-specific time dummies to deal to some degree with this issue. ${ }^{6}$ To the extent that differential dynamic behavior in mortality reflects differences across various areas of the country, this will be captured by different statespecific non-linear trends (time dummies). Still, these possibilities constitute our main concern in the empirical analysis, and we develop various procedures to check the robustness of our results to them. As an initial assessment of how serious these problems may be, at the end of this section we follow Galiani, Gertler, and Schargrodsky (2005) and conduct a hazard estimation of the determinants of the probability that a given municipality joins the program.

\footnotetext{
${ }^{6}$ Note that this strategy also deals, to a great extent, with the measurement problem alluded to in the previous section. Any systematic variation in mortality recording across states at a point in time, or across time within a state, is controlled for by the state-year dummies. The only remaining potential bias due to measurement is related to a situation where recording is systematically improved by the presence by the PSF. But notice that in this case the bias would be in the direction of finding a positive effect of the program on mortality.
} 
Our second concern is related to omitted variables. It is possible that good governments make use of the PSF and also implement various other social policies, in which case we may end up attributing to the PSF an effect that indeed comes from other actions taken by local governments. In order to account for this possibility, we try to control for a wide range of municipality variables, encompassing different dimensions of local policy that may be correlated with the implementation of the PSF and may also lead to improvements in health and reductions in mortality. With this goal in mind, our vector of municipality controls includes the following dimensions: immunization coverage (BCG, measles, yellow fever, poliomyelitis and DTP, without the last two and with DT for adults), ${ }^{7}$ health infrastructure (number of beds and hospitals per capita), and education infrastructure (number of schools and teachers per capita).

Given the considerations above, our benchmark specification in this case is a differencein-difference allowing for heterogeneity in the effect of treatment according to time of exposure to the program, and also allowing for state-specific year dummies. Later on, we explore other possible sources of variation in the effects of the program, such as initial level of mortality and geographic region. The main sources of variation used to identify the effects of the program are: different timing of adoption across municipalities and different time of exposure. So our basic empirical specification is the following:

Health $h_{m t}=\alpha^{h}+\sum_{j=1}^{j} \beta_{j}^{h} \cdot P S F_{m t}^{j}+\gamma^{h} \cdot X_{m t}+\vartheta_{m}^{h}+\mu_{s t}^{h}+\varepsilon_{m t}$,

where Health ${ }_{m t}$ denotes some indicator of health for municipality $m$ in year $t, P S F_{m t}^{j}$ indicates a dummy variable assuming value 1 if municipality $m$ in year $t$ has been in the program for $j$ years, $X_{m t}$ denotes a set of municipality level controls, $\vartheta_{m}{ }^{h}$ is a municipality fixed-effect, $\mu_{s t}{ }^{h}$ is a statespecific year dummy (26 non-linear state-specific trends), $\varepsilon_{m t}$ is a random error term, and $\alpha^{h}$, $B_{j}^{h \prime} s$, and $\gamma^{h}$ are parameters.

\footnotetext{
${ }^{7}$ It is possible that the PSF improves the delivery of immunization. Still, since widespread immunization in Brazil predates the PSF, we want to be able to estimate the effect of the program independently from its effects on immunization. Our qualitative results remain very similar when we exclude the immunization variables from the estimation.
} 
Finally, in order to account for the fact that the variance of mortality is strongly related to population size, we weight the regressions by municipality population. Also, to account for the possibility of serially correlated and heteroskedastic errors, and to avoid overestimation of the significance of estimated coefficients, we cluster standard errors at the municipality level (as suggested by Bertrand, Duflo, and Mullainathan, 2004).

\subsection{Behavioral Impacts}

In the analysis of the impacts of the program on individual behavior, our unit of observation is an individual within a municipality at a point in time. As will be explained later on, we restrict the analysis to regions where the health impacts of the program seem to have been strongest. For obvious reasons, these are also the places where we would hope to find the clearest changes in behavior. In this case, our sample, extracted from the Brazilian National Household Survey, covers 361 municipalities (in the North and Northeast regions). Given the reduced number of municipalities, we also allow for municipality-specific linear trends. This has at least one great advantage in relation to the approach suggested for the case of the health impacts of the program: differential trends across municipalities are immediately controlled for, taking care of one of the main concerns in our previous discussion.

Since the outcomes of interest now are represented by categorical variables indicating discrete states (labor supply, employment, school enrollment, and occurrence of a birth), we estimate probit models (all results are reported as marginal effects). Here again, the main sources of variation used to identify the effects of the program are: different timing of adoption across municipalities and different time of exposure. So our basic specification is the following:

$P\left(\right.$ Behavior $\left._{i m t}=1\right)=\Phi\left(\alpha^{b}+\sum_{j=1}^{j} \beta_{j}^{b} \cdot P S F_{m t}^{j}+\varphi^{b} \cdot Z_{i m t}+\gamma^{b} \cdot X_{m t}+\vartheta_{m}^{b}+\mu_{t}^{b}+\rho_{m}^{b} \cdot t\right)$

where Behavior $_{\text {imt }}$ denotes some discrete indicator for the behavior for individual $i$ in municipality $m$ and year $t, P S F_{m t}^{j}$ indicates a dummy variable assuming value 1 if municipality $m$ in year $t$ has been in the program for $j$ years, $Z_{i m t}$ represents a set of individual level controls, $X_{m t}$ denotes a set of municipality level controls, $\vartheta_{m}{ }^{b}$ is a municipality fixed-effect, $\mu_{t}{ }^{b}$ is a year 
dummy, $t$ represents a linear time trend, $\Phi($.$) is the normal distribution function, and \alpha^{b}, b_{j}^{b,} s$, $\varphi^{b}, \gamma^{b}$, and $\rho_{m}{ }^{b \prime}$ s are parameters. ${ }^{8}$

This specification greatly reduces concerns related to differential dynamic behavior of the dependent variable across municipalities, as those expressed in the last subsection. Still, there remains the possibility of omitted variables associated with other relevant dimensions of policy. In this respect, we follow the same strategy outlined for the case of the municipality level analysis. We also cluster standard errors at the municipality level, to account for the possibility of correlation of residuals within municipalities (across individuals and time) and to avoid overestimation of the significance of estimated coefficients (as suggested by Bertrand, Duflo, and Mullainathan, 2004 in an OLS context).

\subsection{Determinants of Adoption of the Family Health Program}

As an initial assessment of the determinants of adoption of the PSF and of how serious the issue of dynamic endogeneity may be, we follow Galiani, Gertler, and Schargrodsky (2005). We conduct a hazard estimation of the probability that a given municipality joins the program. Specifically, our dependent variable is a dummy indicating the presence of the program in a municipality. As soon as municipalities join the program, they leave the sample. So we estimate the effect of municipalities' characteristics on the probability of joining the program. Our main interest is on how this probability is related to fixed municipality characteristics and to changes in endogenous variables or other policy dimensions. Therefore, our hazard estimation evaluates the probability that a municipality joins the PSF as a function of shocks to health variables (changes in mortality in previous years), changes in other dimensions of public policy, a set of political variables indicating the party of the mayor, ${ }^{9}$ and a set of socioeconomic variables ${ }^{10}$ indicating the initial conditions of the municipality.

\footnotetext{
${ }^{8}$ It is known that fixed-effects estimates are not consistent in probit models, and that this may bias estimates of other parameters. But Fernández-Val (2007) has recently shown that, in this setting, estimates of average marginal effects have negligible bias relative to their true values (for a wide variety of distributions of regressors and individual effects). Since we concentrate our discussion on marginal effects, we proceed with the fixed-effects probit estimation and trust on these results.

${ }_{9}$ During almost the entire period covered by the sample, the Social Democratic Party holds the Brazilian presidential office. Therefore, we do not include dummies indicating whether the mayor belongs to the party of the president, and choose to control only for the identity of the party.

${ }^{10}$ The initial conditions include initial values of: health variables (mortality before 1, between 1 and 4, between 15 and 59, and above 60), public policy variables (hospitals, hospital beds, schools and teachers), average schooling, average age of the head of the household, average number of members in a household, percentage of households in vulnerable socioeconomic conditions ( 4 or more members per working member and head of the household with less than 4 years of schooling), average household income per capita (In), and unemployment rate.
} 
Results of this estimation are presented in the Appendix Table A.2. The first three columns consider, respectively, the $1^{\text {st }}, 2^{\text {nd }}$, and $3^{\text {rd }}$ lags of mortality before age 1 , each at time. The remaining three columns include mortality between ages 1 and 4 and between ages 15 and 59 in the analysis, again considering the $1^{\text {st }}, 2^{\text {nd }}$, and $3^{\text {rd }}$ lags separately. ${ }^{11}$

The results indicate that adoption of the program seems to be correlated with past health shocks, but that the quantitative impacts are extremely small when compared to other variables related to fixed municipality characteristics or political considerations. When looking only at mortality before age 1 , we find that the $2^{\text {nd }}$ or $3^{\text {rd }}$ lag of mortality are positively correlated with program adoption, meaning that past shocks to mortality are positively associated with implementation. But the estimated coefficient implies that even substantial mortality shocks imply only modest increases in the probability of program adoption: a one standard deviation increase in lagged mortality before one increases the probability of program adoption by only 3.5 percentage points. The results are similar when we include lags of mortality in different age groups. When we include the $1^{\text {st }}$ lag of mortality in the three age groups, only mortality between 15 and 59 appears as significant. When we include the $2^{\text {nd }}$ lag, only mortality before age 1 appears as significant. Finally, when we include the $3^{\text {rd }}$ lag, all three are statistically significant, though mortality between 15 and 59 appears with a negative sign. In the first case, a one standard deviation increase in adult mortality is associated with a 3.3 percentage point increase in the probability of program adoption. In the last column, a simultaneous increase of one standard deviation in all mortality rates is associated with an increase of 2.9 percentage points in the probability of program adoption. So, despite being statistically significant, the quantitative impacts of lagged mortality changes in the probability of PSF adoption are quantitatively very small.

In contrast, political considerations as well as initial municipality characteristics are quantitatively very important in determining the timing of program adoption. Municipalities governed by the main left wing parties - Workers Party (PT), Popular Socialist Party (PPS), and Socialist Party (PSB) - and by the Social Democrat Party were more likely to adopt the program in any given year. As briefly mentioned before, through most of our sample period the Social

\footnotetext{
${ }^{11}$ We do not include mortality above age 59 in this analysis because, as will be seen later on, it is not significantly affected by the program. In addition, the cross-municipality variance in old age mortality is relatively small when compared to its mean.
} 
Democrat Party holds the presidency of the country. During this period, the three left wing parties mentioned above were not part of the ruling coalition. So, taken together with the fact that the Social Democrat Party also affected positively the probability of adoption of the PSF, it seems to be the case that adoption was more closely related to ideological orientation or managerial quality, rather than to connections with the central government. Some of the parties in the basis of the ruling coalition - such as the Liberal Front Party or the Brazilian Labor Party - appear as having no impact or even a negative impact on the probability of adoption of the PSF. The estimated coefficients imply that, if the mayor belonged to one of the parties mentioned before, the probability that a municipality would join the program in a given year would be increased by between 20 and 60 percentage points. Political considerations seem to be key in determining program implementation.

Also, several initial characteristics are correlated with early adoption of the program. Overall, the picture is that municipalities in initially worse conditions were more likely to adopt the PSF. So we have that, in terms of initial variables, higher mortality before age 1, lower number of schools per capita, higher number of members per household, and lower income per capita were historically associated with early adoption of the Family Health Program. Doubling household income per capita, for example, is associated with roughly a 22 percentage point reduction in the probability that a municipality joins the program in a given year.

Another interesting aspect suggested by the table is that there seems to be some substitutability across different policy alternatives available to local governments. So municipalities more likely to adopt the PSF are those that have not increased the number of hospitals or the number of schools in recent years. Strangely, though, changes in the number of teachers per capita appear as positively related to program adoption (maybe due to political pressure or politicization of the local population).

In any case, despite being related to initial characteristics of municipalities and being, to some extent, a substitute to other policy dimensions, adoption of the program is not greatly affected by shocks to health. So the dynamic issue of decision of adoption being driven by changes in dependent variables (health outcomes) does not seem to be serious enough to impair the use of the empirical strategy outlined above. Implementation of the program is not closely related to time varying shocks to the dependent variable. In addition, the fact that 
program implementation is greatly affected by political considerations seems to guarantee some degree of exogeneity.

\section{Impact on Mortality}

\subsection{Main Results}

Table 2 presents the results from our baseline specification. The four columns display the estimated coefficients of the effects of the PSF on mortality for four different age groups: before age 1, from age 1 to 4, from age 15 to 59 , and above age 59. The table suggests a strong negative correlation between program exposure and mortality for all age groups below 59, and some mild negative correlation for the age group above 59. Quantitative impacts are particular strong for mortality before age 1 , but in relative terms the impacts are also substantial for other age groups. For example, the estimated coefficients imply that municipalities that have been in the program for three years reduce infant mortality by 1.5 per 1,000 more than otherwise identical municipalities that are not in the program. Taking the 1993 average infant mortality for Brazil (27 per 1,000), this corresponds to a 5.6\% reduction in the infant mortality rate. For a municipality eight years into the program, there is a reduction of 5.4 per 1,000 in infant mortality, corresponding to $20 \%$ of the 1993 national average.

For mortality rate between ages 1 and 4, the coefficients correspond to reductions of $6.4 \%$ (0.07 in absolute terms) for municipalities three years into the program, and $25 \%$ ( 0.28 in absolute terms) for municipalities eight years into the program. Analogous numbers for mortality between ages 15 and 59 are 2.6\% (0.09 in absolute terms) for municipalities three years into the program, and $8.5 \%$ ( 0.29 in absolute terms) for municipalities eight years into the program.

The effect of the PSF on mortality above age 59 is much less robust in terms of significance, and less important in terms of magnitude, than that observed in other age groups. The only treatment dummies that appear as significant are those related to years four and five of implementation. In addition, irrespective of the level of significance, the impacts implied by the point estimates are quite small as compared to the average mortality observed in the age group. So municipalities three years into the program are estimated to experience additional reductions in mortality of 0.34 per 1,000 when compared to municipalities not covered by the program. Taking the 1993 mortality rate above age 59 as a reference point, this represents a 
reduction of only $0.8 \%$ in mortality. The analogous number for municipalities eight years into the program is a reduction in mortality of 1.1 per 1,000 , corresponding in relative terms to only $2.7 \%$ of the 1993 national average.

So Table 2 suggests that the PSF is quite effective in reducing infant mortality, and also seems to have significant impacts on mortality between ages 1 and 4, and 15 and 59 . For the different age groups, Figure 4 illustrates the time profile of the impact of the program as implementation evolves through time. The time span covered by our sample allows us to look only at municipalities that have been in the program for eight years or less. Within this time frame, mortality reductions seem to generally increase with each additional year that a municipality remains in the program. So, for mortality before age 1 , there is an average reduction of 0.68 per additional year in the PSF, while the analogous number for mortality between ages 1 and 4 and 15 and 59 is roughly 0.035 per additional year on the program. ${ }^{12}$

\subsection{Heterogeneity in Response}

In order to better understand how the Family Health Program actually worked, its strengths and weaknesses, we explore some dimensions of potential heterogeneity in response. Heterogeneity in response may be related to, among other things, initial conditions, geographic characteristics, or specific causes of death. In this subsection, we explore the differential impact of the program along these three dimensions.

Regions

Table 3 presents results from regressions identical to those from Table 2, but ran separately for each of the five geographic regions of Brazil: South, Southeast, Center-West, Northeast, and North. The results are impressive: the two poorest regions, which are also those with lower provision of several public goods - the North and the Northeast - are by far the ones enjoying the greatest benefits from the program. ${ }^{13}$ In the North, a municipality eight years into the program is estimated to experience a reduction of 15.0 per 1,000 in infant mortality

\footnotetext{
${ }^{12}$ This result is not due to municipality heterogeneity correlated with time of exposure to the program. In the Appendix Table A.3, we interact the treatment dummies of Program Year 3, Program Year 4, and Program Year 5 with dummies indicating "early movers" (municipalities that joined the PSF during the first three years). The results remain unchanged, and the interactions of treatment dummies with "early movers" are not statistically significant. So the larger effect for municipalities that have been in the program for a long time is not related to some unobserved characteristic of these "early movers."

${ }^{13}$ For example, in the beginning of the period under analysis (1993), income per capita was $R \$ 2,810$ in the Northeast and $R \$ 4,630$ in the North, against a national average for Brazil of $R \$ 6,280$ (values in $R \$$ of 2000 , from www.ipeadata.gov.br).
} 
rate, while the analogous reduction for the Northeast is 13.8 per 1,000 . The impact of the program for these two regions appear as significant and large in magnitude for all age groups analyzed, including mortality above 59, which did not appear as significantly affected by the program in the aggregate analysis. For the Northeast, municipalities eight years into the program display reductions in mortality of 5.0 per 1,000 , which, when compared to the mortality rate for the age group in 1993 , correspond to a decline of roughly $12.5 \%$. Results in the North and Northeast are similarly strong and consistent in the remaining two age groups (1 to 4 and 15 to 59$)$.

In relation to other regions, there is some evidence on the significant impact of the PSF on mortality between 1 and 4 and 15 and 59 in the Southeast, and on mortality between 15 and 59 and above 59 in the Center-West, but in neither case results are as robust as for the North and Northeast.

\section{Initial Mortality}

Table 4 presents the results on the impact of the PSF by initial mortality deciles, for the five highest initial mortality deciles. For each age group, municipalities are classified into deciles according to 1993 mortality levels, and then the same specification from Table 2 is estimated for each decile in each age group (the results are presented only for the five highest initial mortality deciles).

For mortality before age 1 , the impact of the program seems to be strongest for the top two initial mortality deciles. But the standard errors of the estimated coefficients are very high, possibly due to a lower number of observations, and the point estimates for the $9^{\text {th }}$ decile are not statistically significant. For the $10^{\text {th }}$ decile, point estimates are systematically larger than those from Table 2, suggesting that the impact of the program on mortality before age 1 was stronger in municipalities with initially higher mortality levels.

For mortality between ages 1 and 4 and 15 and 59 - the ones that were significantly affected by the PSF according to the estimates from Table 2 - most of the point estimates are negative but non-significant. Also, there is no clear systematic difference in magnitude when compared to the coefficients from Table 2. For mortality between ages 1 and 4, there are significant effects of the program estimated for the $6^{\text {th }}$ and $9^{\text {th }}$ deciles, while for mortality between ages 15 and 59, there are significant effects estimated for the $7^{\text {th }}$ and $9^{\text {th }}$ deciles. 
Overall, the large impacts estimated for the North and Northeast regions do not seem to be mostly attributable to their initially higher mortality levels. Though the impact of the PSF on infant mortality seems to have been particularly strong for municipalities with initially high infant mortality, the same thing is not true for mortality in other age groups. For mortality above 1 , our results were not able to consistently identify differences in the impact of the program according to initial mortality levels.

\section{Urbanization and Public Health Infrastructure}

Tables 5, 6 and 7 present the results according to initial (1991) levels of urbanization, access to treated water, and availability of public sewerage system. Results are in line with the regional estimates from Table 3, and are more robust than the results by initial mortality levels from Table 4. Municipalities with lower fraction of urban population, with fewer households with access to treated water, and fewer households with toilet connected to the public sewage system display higher responses to the implementation of the PSF. These are also likely to be municipalities with initially higher mortality levels, but since mortality for a specific year in small municipalities tends to be somewhat noisy, it is likely that the variables analyzed in Tables 5, 6 and 7 are better able to capture the overall socioeconomic profile of a given location. In all these dimensions, initially worse-off municipalities seem to benefit particularly from program implementation.

\section{Cause of Death}

In order to shed further light on the driving forces behind the impacts of the Family Health Program, Tables 8(a), 8(b), and 8(c) decompose the effect of the PSF on mortality by cause of death. In the case of adult mortality (between ages 15 and 59), we also decompose mortality by gender (Table $8(\mathrm{c})$ ). Each table presents the same specification from Table 2 for a particular age group, for mortality decomposed by the main causes of death within that age group. The causes of death considered for each age group are the following (see Appendix Table A.3 for a detailed description of the specific causes of death included in each group mentioned below): ${ }^{14}$

\footnotetext{
${ }^{14}$ We also experimented with morbidity data based on hospital admissions by place of residence, but found no significant impact of the program on any age group or disease. It is not clear whether this is due to reporting error in the data, or to the fact that the PSF may facilitate hospital access for certain fractions of the population. Given that most of health problems do not culminate in death, one should expect the impact of the Family Health Program on general health to be stronger than the impact on mortality estimated here.
} 
$\rightarrow$ mortality before age 1: perinatal period conditions, infectious diseases, external causes, endocrine diseases, respiratory diseases, congenital anomalies, nervous systems and senses organs diseases, and ill-defined conditions;

$\rightarrow$ mortality between 1 and 4: neoplasms, infectious diseases, external causes, endocrine diseases, respiratory diseases, congenital anomalies, nervous system and senses organs diseases, and ill-defined conditions;

$\rightarrow$ mortality between 15 and 59: neoplasms, external causes, endocrine diseases, respiratory diseases, circulatory diseases, digestive diseases, and ill-defined conditions; and

$\rightarrow$ mortality above 60: neoplasms, external causes, endocrine diseases, respiratory diseases, circulatory diseases, and ill-defined conditions.

For mortality before 1 , Table 8 (a) shows significant impacts of the program on perinatal period conditions, infectious diseases, endocrine diseases, respiratory diseases, and, less robustly, on congenital anomalies and ill-defined conditions. Most of these estimated effects are in line with what should be expected from the type of intervention implied by the program. The effect on ill-defined conditions during the first years of implementation, which may seem strange at first sight, is probably due to the fact that presence of the PSF is associated with a reduction in the number of deaths without proper diagnosis (reduction in the measurement error in cause of death). ${ }^{15}$ Quantitatively, the largest impacts of the program on this age group are associated with mortality due to perinatal period conditions, infectious diseases, and respiratory diseases. These three causes of death include, for example, problems associated with complications during pregnancy, diarrhea and other intestinal diseases, influenza, asthma, and bronchitis. These are precisely conditions against which the kind of support and information provided by the presence of the Family Health Program should be most effective. It is very reassuring that our results related to infant mortality paint a picture entirely consistent with the technology that constitutes the main intervention of the PSF. As a final point attesting to the consistency of our results, when we sum over all the coefficients associated with

\footnotetext{
${ }^{15}$ Notice that this interpretation is consistent with the fact that the effect on ill-defined conditions is reduced in magnitude and ceases to be significant after year 6 . Also, this interpretation means that a fraction of the deaths that before were registered as due to ill-defined conditions are now properly classified into some other cause of death. This would imply an artificial increase in the number of deaths attributable to the causes, which in turn would tend to minimize the estimated impact of the program on these other causes of death. So, if anything, our estimates on other causes of death are likely to be slightly biased toward zero.
} 
Program Year 8 on Table 8(a), we end up with an aggregate impact on mortality of -5.15 per 1,000 , which is very close to the aggregate effect on mortality presented on Table $2(-5.44)$.

In the age group between 1 and 4, the significant effects of the PSF are associated with mortality due to infectious diseases, external causes, endocrine diseases, and respiratory diseases. The causes of death affected by the program are similar to those in the age group before 1 , but for the absence of perinatal period conditions and the presence of external causes. Since accidents are more common in this age group, and the PSF also provide first aid support in some of these cases, this result is not surprising. Quantitatively, the largest impacts of the program in this age group are associated with mortality due to infectious and respiratory diseases. Again, the set of diseases considered exhausts most of the aggregate effects on mortality presented on Table 2: the sum of the coefficients associated with Program Year 8 leads to an overall impact on mortality of -0.24 per 1,000 , as compared to -0.28 estimated before.

Table 8(b) shows that, in the age group between 15 and 59, the Family Health Program appears as having significant impacts on mortality due to external causes, endocrine, respiratory, circulatory, and digestive diseases. These are some of the causes of death that appeared as important in the age group between 1 and 4, plus circulatory and digestive diseases, which are typically adult conditions (including heart and cerebrovascular diseases, gastric ulcer, liver cirrhosis, and other liver diseases). Again, some of these conditions can be affected - through changes in diet or behavior, for example - by the information, monitoring, and guidance provided by the Family Health Program. Quantitatively, the largest impacts on this age group are observed for external causes, endocrine and respiratory diseases. Considering municipalities eight years into the program, the causes of death analyzed in Table 8(b) account for an aggregated impact on mortality between 15 and 59 of -0.25 per 1,000, as compared to -0.29 presented in Table 2.

Also, as before, Table $8(\mathrm{~b})$ shows that, for the population above 59 , the evidence on the impacts of the program is rather weak. There are only some significant impacts on mortality by ill-defined causes and, surprisingly, some positive impacts on mortality due to neoplasms. Since these are relatively small in magnitude and seem to appear precisely when there are significant reductions in mortality due to ill-defined causes, we do not attach much weight to these 
results. It seems fair to say that there is no consistent evidence on the effects of the program on mortality above 59.

Finally, Table 8(c) breaks down the adult mortality results by gender. The table shows that reductions in male mortality come mainly from external causes, but also from endocrine diseases and ill defined-conditions. Given the level of violence currently observed in Brazil, and the fact that violence is mainly a male phenomenon, this should be no surprise. In the case of female mortality, quantitative effects are much weaker, being also associated with external causes and endocrine diseases, but in addition with digestive and respiratory diseases, and pregnancy complications.

\subsection{Robustness of the Impact on Mortality}

As mentioned before, our basic specification already controls for various policy changes that may also affect health and be confounded with the PSF. In addition, our difference-indifference specification takes care of time invariant characteristics of municipalities, of heterogeneous effects according to time of exposure to the program, and of different nonlinear time trends across states. Finally, the exercises conducted revealed various dimensions of heterogeneity in response to the program, many of which are consistent with what should be expected from the design and technology implicit in the intervention.

The main remaining concern is related to unobserved features of the dynamic behavior of mortality, coupled with the possibility of endogeneity in the adoption of the program. So, if municipalities adopting the program are systematically different in terms of the dynamic behavior of mortality, our estimates may be biased. This may be the case, for example, if the program dummies are just capturing pre-existing trends in mortality, rather than the impact of the intervention. It may also be the case if municipalities that start-off with high mortality tend to converge to lower mortality levels, as seems to be the case in recent decades in Brazil (see Soares, 2007a). In this case, if high mortality municipalities are also more likely to adopt the program, one might attribute to the program an effect that is simply due to mortality convergence across municipalities.

Our analysis of the adoption of the program in section 4.3 suggests that these concerns do not seem particularly relevant in our case. Table A.2 showed that adoption of the program was related to political considerations and initial characteristics of municipalities, but did not seem to be greatly affected by shocks to mortality. Still, we take these possibilities seriously and 
adopt two strategies to deal with them. First, we introduce dummies indicating number of years before the program. If the effect of the PSF estimated before is due to pre-existing trends in mortality, these pre-program dummies should be significant. Second, we introduce an interaction of a linear time trend with initial mortality. This allows each municipality to converge to its state specific non-linear trend, at a rate that may vary with its initial conditions, so that municipalities with different mortality levels in 1993 may display different dynamics in the behavior of mortality. We apply these procedures to the same specification used on Table 2, and present the results on Tables 9 and 10.

Table 9 presents the results for the pre-existing trends exercise. For none of the age groups analyzed, pre-existing trends seem to be an issue. Estimated coefficients for the preprogram dummies are quantitatively small and, in the vast majority of cases, far from significant (from the 32 pre-treatment coefficients displayed, only two turn out to be positive and statistically significant at the $10 \%$ level). Results for the coefficients on the program dummies remain very similar to those estimated on Table 2.

Table 10 presents the results when we control for an additional interaction between initial mortality and a time trend. Qualitative results remain similar to those from Table 2: there are significant effects of the program on mortality before age 1 , between ages 1 and 4 , and between ages 15 and 59. Quantitatively, coefficients are smaller than those estimated before, indicating that there seems to be some convergence in mortality correlated with adoption of the PSF. Still, the pattern of convergence is not enough to explain the significant effects of the Family Health Program estimated before. In reality, given the evidence above, it is even likely that part of the recent convergence in mortality is driven by the expansion of the PSF through different areas of the country, so that this may constitute indeed a very extreme test of the effectiveness of the program.

Overall, the robustness exercises suggest that there is a causal negative effect of the Family Health Program on mortality. This effect appears to be particularly strong in the poorer regions of Brazil, and for mortality at early ages. It is very likely that these mortality reductions are also associated with improvements in health along various other dimensions. If that is the case, it is possible that program implementation also generates changes in household behavior. We tackle this issue in the next section. 


\section{Impact on Individual Behavior}

\subsection{Main Results}

As the previous section highlighted, the impacts of the family health program were particularly strong in the North and Northeast regions of Brazil. Therefore, in order to try to uncover the effects of the program on household behavior, we focus on these two regions, since they are most likely to reveal the individual responses that can arise due to the intervention.

During our sample period, the Brazilian Household Survey (PNAD) covers 316 municipalities in these areas. We construct a repeated cross-section with 10 rounds of the PNAD, restricting the sample of children to individuals aged between 10 and 17 and the sample of adults to individuals aged between 18 and 55. This leaves us with datasets of 118,269 children and 279,943 adults. We focus on variables that can be either affected by the change in incentives brought about by changes in health, or directly affected by the presence of the Family Health Program. Therefore, our variables of interest are child labor (work during the previous week), school enrollment of children, ${ }^{16}$ labor supply and employment status of adults (work during the previous week), and fertility of women (a birth during the year of the interview or the previous calendar year, corresponding to the last 21 months).

Descriptive statistics for these variables are presented on Table 11. Program coverage among the 316 municipalities considered grew from 0 in 1993 to 291 (92\%) in 2004. As the table shows, even these poor areas of Brazil experienced substantial improvement between 1993 and 2004. The incidence of child labor between ages 10 and 17 was reduced from 32\% to $20 \%$, while school enrollment in the same age group increased from $78 \%$ to $91 \%$. Labor supply of adults between 18 and 55 increased from 74\% to 77\%, while employment remained roughly constant, around $71 \%$. At the same time, fertility - as measured by the probability that a woman experiences a birth over a 21 month interval - was reduced from 19\% to $12 \%$.

\section{Child Labor and Schooling}

Table 12 presents the results related to the impacts of the PSF on child labor and school enrollment. Overall, there is almost no noticeable effect of the program on child labor, while there seems to be a positive effect on school enrollment. Eight years of exposure to the

\footnotetext{
${ }^{16}$ Ideally, we would measure the impact of the program on school attendance. The PNAD does not provide this type of information, so we focus on school enrollment.
} 
program are associated with an increase of $4.5 \%$ in the school enrollment of children between 10 and 17.

To explore the possibility of heterogeneous responses across genders and age groups, the table also breaks down the sample between boys and girls, and between ages 10 to 14 and 15 to 17 . There is some evidence that the program may have increased the labor supply of boys between the ages of 10 and 14, but overall the child labor results remain non-significant. The estimates for school enrollment indicate stronger effects for boys and girls between ages 15 and 17 (point estimates are slightly higher for boys than girls), consistent with the ideas that school enrollment below 14 was already very high by the end of the 1990s and that boys drop out of school before girls. ${ }^{17}$

Positive impacts on school enrollment and child labor might be consistent if improvements in health increased productivity on the labor market and on investments in human capital, reducing idle time. Since these activities are not mutually exclusive, this is possibility. Despite lack of significance of most of the effects on child labor, if anything, this is the overall pattern suggested by the point estimates on Table 12.

\section{Labor Supply and Employment}

Table 13 presents the results on the response of adult labor supply and employment. The top panel presents results for labor supply, while the bottom panel presents the results for employment. Inside each panel, the first three columns show the results both genders (ages between 18 and 55), and for men and women separately, while the remaining columns break down these results by age groups.

The table suggests a consistent effect of the PSF on adult labor supply and employment. Municipalities eight years into the program have adult labor supply 6.8 percentage points higher and employment 11 percentage points higher than otherwise equivalent municipalities not covered by the program. Quantitative results for both labor supply and employment are stronger for women than for men, though significance is reduced as the sample is broken down by gender. Significance is also greatly reduced when the sample is broken down by age group

\footnotetext{
${ }^{17}$ Though not reported here, we also investigated the impact of the PSF on teenage pregnancies and found no significant effects. These results are available from the authors upon request. We cannot rule out the possibility that the positive effects on schooling are spillovers from the interaction of health agents with families, possibly through counseling and advising regarding multiple aspects of family life.
} 
and gender, but in all cases it remains true that point estimates are higher for women than for men.

The only significant effects for men are found in the case of employment in all ages, and employment between ages 41 and 55. It is reassuring that employment of older men is the one most affected by the presence of the PSF, since they are the ones most likely to face health conditions that may reduce employability. The impacts estimated for other age groups are much smaller in magnitude and not significant. In the case of women, though point estimates are always larger than men's, coefficients are not significant when the sample is broken down into age groups.

Fertility

Table 14 presents the results related to fertility (probability of a birth over the 21 months preceding the interview). Results are also quite strong. Implementation of the PSF seems to be systematically associated with reduced probability of women experiencing births. The average effect for women between ages 18 and 55 registered in the first column is due mostly to women between 31 and 40, though there are also negative but mostly non-significant impacts for women between 18 and 30. Given that Table 13 showed evidence of significant impacts of the program on labor supply and employment of women, the impact on fertility may be either due to better access to - or information about - contraceptive techniques, or to improved health of adults and existing children (change in long-term lifetime decision on labor supply affecting fertility choice). Again, the age profile of the estimated response is consistent with what should be expected: we find no significant effect of the PSF on fertility between 41 and 55, an age group where fertility is typically much lower and undesired pregnancies much rarer.

Quantitatively, the estimated coefficients for the age group between 31 and 40 imply that, for municipalities five years into the program, women are 4.6 percentage points less likely to have experienced a birth in the previous 21 months than otherwise identical women in municipalities not covered by the PSF. The analogous number for municipalities eight years into the program is 6.5 percentage points.

Overall, the evidence suggests that the Family Health Program increased employment opportunities for older men, while, at the same time, fertility was reduced, and female labor supply and school enrollment of children increased. These effects are consistent with what 
should be expected from improvements in health and their effects on decision related to human capital, number of children, and labor supply.

\subsection{Heterogeneity in Response}

In order to better understand the impact of the Family Health Program on household decisions, we explore some dimensions of potential heterogeneity in response. In this section, we investigate heterogeneity in response in relation to the location where the family lives (rural vs. urban) and to conditions of the household (no access to treated water and no access to the public sewage system). Tables 15, 16, and 17 present the results for, respectively, child labor and schooling, adult labor supply and employment, and fertility.

As before, Table 15 shows that there is no robust significant effect of the program on child labor. The effect on school enrollment, in turn, is stronger for households in rural areas and for those without access to treated water. The coefficients for municipalities eight years into the program for these two regressions are, respectively, 0.058 and 0.064 , as compared to 0.045 in the main specification of Table 12.

For adult labor supply and employment, effects are also much stronger in rural areas (Table 16). The results appear as significant and of magnitude similar to that observed on Table 13 for households without toilet connected to the public sewage system. In the cases of both child schooling and adult labor, the impact of the program seems to be associated with poor households in rural areas, possibly with less access to the public health system.

In the case of fertility, on the other hand, the effect comes entirely from households in urban areas (Table 17). It is still true that poorer households, with less access to the public sewage system and less access to treated water, seem to experience higher reductions in fertility after implementation of the program, but this effect is entirely associated with urban areas. This may indicate that reductions in fertility are driven by improved access to contraceptive techniques by households that already had some demand for birth control methods. If such demand did not exist in rural areas, the results from Tables 16 and 17 would be consistent.

\section{Concluding Remarks}

This paper shows that implementation of the Brazilian Family Health Program was associated with reductions in mortality throughout the age distribution, but particularly at very 
early ages (infant mortality). The response to the program seems to be particularly strong in municipalities with worse off initial conditions and in the poorest regions of Brazil (North and Northeast). For example, a municipality eight years into the program is estimated to experience a reduction in infant mortality of 15 per 1,000 in the North and 14 per 1,000 in the Northeast, as compared to the 1993 national average of 27 for this variable. The reductions in mortality determined by the program are mostly associated with perinatal period conditions, infectious, endocrine, and respiratory diseases, and, for older age groups, external causes and digestive diseases. In the North and Northeast regions of the country, we also find that program implementation was significantly associated with reduced fertility, increased labor supply of adults, and increased school enrollment.

Given the estimated impacts presented on Table 2 and the costs of implementation calculated elsewhere (Fundação Getulio Vargas and EPOS Health Consultants, 2001), we can conduct some preliminary cost-benefit analysis of program implementation, based on yearly costs and the number of lives saved. For example, a municipality with 100,000 inhabitants, subject to the average program coverage observed in the sample (40\%), should be expected to spend between US\$1,252,688 and US\$1,981,714 yearly to run the program. Assuming that such municipality would have the same age distribution of the Brazilian population in 2000, and taking the point estimates from Table 2 as being accurate, this municipality would save a cumulative total of 57 lives after five years of PSF implementation, and 150 lives after 8 years. Given the range of estimates available in the literature for the value of a statistical life (see Viscusi and Aldy, 2003), irrespective of the interest rate, this back of the envelope calculation suggests that the Family Health Program is highly effective from a cost-benefit perspective as a tool to promote health improvements. If, on top of that, one considers the indirect effect on household behavior estimated here and the morbidity effects that are also likely to be present, the figure would become even more positive.

In short, our results confirm the importance and effectiveness of family and community based health interventions as tools to improve health in economically disadvantaged areas. Nevertheless, replicability of this effort in other contexts requires a certain degree of institutional development to allow for the coordination of actions and monitoring of performance of heath teams. Similarly, labor costs, that constitute the highest fraction of costs of the Family Health Program, depend on specific labor market conditions and on the wage 
differentials required to convince medical doctors and health professionals to work in the relevant regions. These aspects should be explicitly taken into account when considering the implementation of this type of intervention in poor areas of other developing countries.

\section{References}

Bertrand, Marianne, Esther Duflo, and Sendhil Mullainathan (2004). How Much Should We Trust Differences-in-Differences Estimates? Quarterly Journal of Economics, 119(1), 249275.

Bleakley, Hoyt and Fabian Lange (2009). Chronic Disease Burden and the Interaction of Education, Fertility, and Growth. Review of Economics and Statistics, 91(1), 52-65.

Bobonis, Gustavo J., Edward Miguel, Charu Puri-Sharma (2006). Anemia and School Participation. Journal of Human Resources, XLI(4), 692-721.

Brazilian Ministry of Health (2006a). Atenção Básica e a Saúde da Família. Ministério da Saúde Brasil, Departamento de Atenção Básica, Brasília (http://dtr2004.saude.gov.br/ dab/atencaobasica.php).

Brazilian Ministry of Health (2006b). Saúde da Família no Brasil: Uma Análise de Indicadores Selecionados, 1998 - 2004. Série C Projetos, Programas e Relatórios. Ministério da Saúde Brasil, Brasília.

Caldwell, John C. (1986). Routes to Low Mortality in Poor Countries. Population and Development Review, 12(2), 171-220.

Fernández, Mercedes, Sebastián Galiani, and Ernesto Schargrodsky (2006). Targeted Interventions in Healthcare: The Role of Facility Placement. Fiscal Studies, 27(3), 373-395.

Fernández-Val, Iván (2007). "Fixed Effects Estimation of Structural Parameters and Marginal Effects in Panel Probit Models." Boston University, unpublished manuscript.

Fundação Getulio Vargas and EPOS Health Consultants (2001). "Determinação e Avaliação do Custo do Programa de Saúde da Família - PSF." Fundação Getúlio Vargas, unpublished manuscript.

Lorentzen, Peter, John McMillan, and Romain Wacziarg (2007). Death and Development. Journal of Economic Growth, 13(2), 81-124.

Kalemli-Ozcan, Sebnem (2002). Does Mortality Decline Promote Economic Growth? Journal of Economic Growth, 7, 411-39.

Kalemli-Ozcan, Sebnem (2006). "AIDS, Reversal of the Demographic Transition and Economic Development: Evidence from Africa." NBER Working Paper n12181.

Galiani, Sebastian, Paul J. Gertler, and Ernesto Schargrodsky (2005). Water for Life: The Impact of the Privatization of Water Services on Child Mortality. Journal of Political Economy, 113(1), 83-120. 
Lleras-Muney, Adriana and Seema Jayachandran (2009). Longevity and Human Capital Investments: Evidence from Maternal Mortality Declines in Sri Lanka. Quarterly Journal of Economics, 124(1), 349-397.

Macinko, James, Frederico Guanais, and Maria de Fatima Marinho de Souza (2006). Evaluation of the Impact of the Family Health Program on Infant Mortality in Brazil, 1990-2002. Journal of Epidemiology \& Community Health, 60(1), 13-19.

Macinko, James, Celia Almeida, and Paulo de Sá (2007). A Rapid Assessment Methodology for the Evaluation of Primary Care Organization and Performance in Brazil. Health Policy \& Planning, 22(3), 167-77.

Meltzer, David (1992). "Mortality Decline, the Demographic Transition and Economic Growth," Ph.D. Dissertation, Department of Economics, University of Chicago.

Miguel, Edward and Michael Kremer (2004). Worms: Identifying Impacts on Education and Health in the Presence of Externalities. Econometrica, 72(1), 159-217.

Paes, Neir Antunes and Marconi Edson Esmeraldo Albuquerque (1999). Avaliação da Qualidade dos Dados Populacionais e Cobertura dos Registros de Óbitos para as Regiões Brasileiras. Revista de Saúde Pública, 33(1), 33-43.

Riley, James C. (2005). Poverty and Life Expectancy. Cambridge University Press, Cambridge.

Riley, James C. (2007). Low Income, Social Growth, and Good Health - A History of Twelve Countries. University of California Press, Berkeley and Los Angeles.

Secretaria de Políticas de Saúde - Departamento de Atenção Básica (2000). Programa Saúde da Família. Revista de Saúde Pública, 34(3), 316-319.

Soares, Rodrigo R. (2005). Mortality Reductions, Educational Attainment, and Fertility Choice. American Economic Review, 95(3), 580-601.

Soares, Rodrigo R. (2007a). Health and the Evolution of Welfare across Brazilian Municipalities. Journal of Development Economics, 84(2), 590-608.

Soares, Rodrigo R. (2007b). On the Determinants of Mortality Reductions in the Developing World. Population and Development Review, 33(2), 247-287.

Viscusi, W. Kip e Joseph E. Aldy (2003). The value of a statistical life: A critical review of market estimates throughout the world. Journal of Risk and Uncertainty, 27(1), 5-76. 
Table 1: Descriptive Statistics, Brazilian Municipalities Covered and Not Covered by the Family Health Program, 1993-2004

\begin{tabular}{|c|c|c|c|c|c|c|c|c|c|c|c|}
\hline \multirow[t]{2}{*}{ year } & \multirow{2}{*}{$\begin{array}{c}\text { N Municip. } \\
\text { Covered }\end{array}$} & \multicolumn{2}{|c|}{ Mort. before 1} & \multicolumn{2}{|c|}{ Mort. between 1 and 4} & \multicolumn{2}{|c|}{ Mort. between 15 and 59} & \multicolumn{2}{|c|}{ Mort. above 59} & \multicolumn{2}{|c|}{ GDP per capita } \\
\hline & & not covered & covered & not covered & covered & not covered & covered & not covered & covered & not covered & covered \\
\hline 1993 & 0 & 27.1 & & 1.1 & & 3.4 & & 40.9 & & & \\
\hline 1994 & 55 & 26.0 & & 1.1 & & 3.4 & & 40.7 & & & \\
\hline 1995 & 150 & 23.8 & & 1.0 & & 3.5 & & 40.6 & & & \\
\hline 1996 & 228 & 23.0 & 27.9 & 1.0 & 1.1 & 3.2 & 3.9 & 37.9 & 41.0 & & \\
\hline 1997 & 567 & 21.3 & 25.1 & 0.9 & 1.0 & 3.2 & 3.6 & 37.6 & 39.6 & & \\
\hline 1998 & 1134 & 20.2 & 25.3 & 0.9 & 1.1 & 3.3 & 3.3 & 39.0 & 40.3 & & \\
\hline 1999 & 1647 & 19.1 & 23.3 & 0.8 & 1.0 & 3.3 & 3.2 & 39.6 & 40.0 & 6,134 & 5,335 \\
\hline 2000 & 2766 & 18.4 & 22.3 & 0.8 & 0.9 & 2.9 & 3.2 & 34.2 & 36.6 & 6,127 & 5,546 \\
\hline 2001 & 3684 & 16.4 & 19.6 & 0.8 & 0.8 & 2.9 & 3.2 & 34.8 & 37.1 & 7,302 & 6,770 \\
\hline 2002 & 4161 & 15.1 & 18.2 & 0.7 & 0.8 & 3.0 & 3.2 & 35.9 & 37.7 & 8,537 & 7,447 \\
\hline 2003 & 4488 & 15.3 & 17.4 & 0.7 & 0.8 & 3.0 & 3.1 & 36.8 & 38.5 & 10,283 & 8,448 \\
\hline 2004 & 4664 & 14.4 & 16.0 & 0.7 & 0.7 & 2.9 & 3.1 & 38.2 & 39.3 & 11,624 & 9,547 \\
\hline
\end{tabular}

Notes: Mortality rates by 1,000 population of relevant age group. We do not have information on the specific municipalities covered in 1994 and 1995 . Municipality GDP is not available on na annual basis before 1999 . 
Table 2: Mortality Regressions by Age Group and sex, Brazilian Municipalities, 1993-2004

\begin{tabular}{|c|c|c|c|c|c|c|c|c|c|c|c|c|}
\hline & \multicolumn{12}{|c|}{ Dependent Variable: Mortality by Age Group and Sex } \\
\hline & \multicolumn{4}{|c|}{ All } & \multicolumn{4}{|c|}{ Men } & \multicolumn{4}{|c|}{ Women } \\
\hline & Before 1 & Btwn 1 and 4 & Btwn 15 and 59 & Above 59 & Before 1 & Btwn 1 and 4 & Btwn 15 and 59 & Above 59 & Before 1 & Btwn 1 and 4 & Btwn 15 and 59 & Above 59 \\
\hline \multirow[t]{2}{*}{ Program Year 1} & $-0.5690 * *$ & $-0.0322 * *$ & $-0.0397^{* *}$ & -0.0713 & -0.1289 & -0.0222 & -0.0032 & 0.0076 & -0.2423 & -0.0267 & $-0.0355^{* * *}$ & 0.1718 \\
\hline & $(0.2701)$ & $(0.0156)$ & $(0.0165)$ & $(0.1832)$ & $(0.3549)$ & $(0.0205)$ & (0.0299) & $(0.1988)$ & $(0.2641)$ & $(0.0187)$ & $(0.0128)$ & $(0.1745)$ \\
\hline \multirow[t]{2}{*}{ Program Year 2} & $-0.7614^{* *}$ & $-0.0494 * * *$ & $-0.0790 * * *$ & -0.2396 & -0.1964 & $-0.0474 * *$ & $-0.0725 * *$ & -0.3433 & $-0.5662 *$ & -0.0277 & $-0.0368 * *$ & 0.1530 \\
\hline & $(0.3386)$ & $(0.0172)$ & $(0.0200)$ & $(0.2234)$ & (0.3894) & $(0.0229)$ & $(0.0287)$ & $(0.2593)$ & $(0.3048)$ & $(0.0201)$ & $(0.0145)$ & (0.2068) \\
\hline \multirow[t]{2}{*}{ Program Year 3} & $-1.8144^{* * *}$ & $-0.0707^{* * *}$ & $-0.1142 * * *$ & $-0.5590 * *$ & $-1.2141 * *$ & $-0.0501 *$ & $-0.1233^{* * *}$ & $-0.5305^{*}$ & $-1.5399 * * *$ & $-0.0766 * * *$ & $-0.0644 * * *$ & -0.0449 \\
\hline & $(0.4706)$ & $(0.0231)$ & $(0.0252)$ & $(0.2544)$ & $(0.4981)$ & (0.0289) & $(0.0371)$ & (0.2829) & $(0.3969)$ & $(0.0259)$ & $(0.0160)$ & $(0.2240)$ \\
\hline \multirow[t]{2}{*}{ Program Year 4} & $-2.6899 * * *$ & $-0.1159 * * *$ & $-0.1595 * * *$ & $-0.8310 * *$ & $-2.1183^{* * *}$ & $-0.1320 * * *$ & $-0.2122 * * *$ & $-0.7886 * *$ & $-2.1469 * * *$ & $-0.0755^{* *}$ & $-0.0634 * * *$ & -0.3931 \\
\hline & (0.6706) & $(0.0279)$ & $(0.0323)$ & $(0.3802)$ & $(0.7173)$ & $(0.0336)$ & $(0.0477)$ & $(0.3695)$ & $(0.5808)$ & $(0.0305)$ & $(0.0212)$ & (0.3309) \\
\hline \multirow[t]{2}{*}{ Program Year 5} & $-3.6592 * * *$ & $-0.1626 * * *$ & $-0.1989 * * *$ & $-0.9035^{* *}$ & $-2.8207^{* * *}$ & $-0.1581^{* * *}$ & $-0.2265 * * *$ & $-0.9998^{* *}$ & $-2.9048 * * *$ & $-0.1502^{* * *}$ & $-0.0861 * * *$ & -0.2915 \\
\hline & $(0.8202)$ & $(0.0373)$ & $(0.0407)$ & $(0.3917)$ & $(0.9728)$ & (0.0449) & $(0.0593)$ & $(0.4026)$ & $(0.7312)$ & $(0.0399)$ & $(0.0247)$ & $(0.3215)$ \\
\hline \multirow[t]{2}{*}{ Program Year 6} & $-4.5655^{* * *}$ & $-0.2158^{* * *}$ & $-0.2642 * * *$ & $-1.0685^{* *}$ & $-3.9908 * * *$ & $-0.2503 * * *$ & $-0.3049 * * *$ & -0.8122 & $-3.8354 * * *$ & $-0.1871^{* * *}$ & $-0.1242 * * *$ & -0.3296 \\
\hline & (1.1021) & $(0.0432)$ & $(0.0470)$ & $(0.4926)$ & $(1.2634)$ & $(0.0502)$ & $(0.0768)$ & $(0.5006)$ & $(0.9466)$ & $(0.0449)$ & $(0.0302)$ & (0.4297) \\
\hline \multirow[t]{2}{*}{ Program Year 7} & $-4.0427 * * *$ & $-0.2160 * * *$ & $-0.2882^{* * *}$ & $-1.2634 * *$ & $-3.6248 * *$ & $-0.1657^{* *}$ & $-0.2740 * * *$ & $-1.4484^{*}$ & $-3.2341 * * *$ & $-0.2361 * * *$ & $-0.1262 * * *$ & -0.0765 \\
\hline & $(1.2616)$ & $(0.0515)$ & $(0.0631)$ & $(0.5871)$ & (1.6414) & $(0.0753)$ & $(0.0982)$ & $(0.7666)$ & $(1.1961)$ & $(0.0591)$ & $(0.0479)$ & (0.6016) \\
\hline \multirow[t]{2}{*}{ Program Year 8} & $-5.4048 * * *$ & $-0.2560 * * *$ & $-0.3834 * * *$ & $-1.2114 *$ & $-5.7023 * * *$ & $-0.3221 * * *$ & $-0.4063^{* * *}$ & $-1.7192 *$ & $-4.5751 * * *$ & $-0.2076 * * *$ & $-0.1559 * * *$ & -0.2330 \\
\hline & $(1.5642)$ & $(0.0562)$ & $(0.0702)$ & $(0.7170)$ & $(2.1309)$ & (0.0794) & $(0.1150)$ & $(1.0025)$ & $(1.5973)$ & $(0.0677)$ & $(0.0592)$ & $(0.7391)$ \\
\hline $\begin{array}{l}\text { Municipality f.e. } \\
\text { State-specific year }\end{array}$ & yes & yes & yes & yes & yes & yes & yes & yes & yes & yes & yes & yes \\
\hline f.e. & yes & yes & yes & yes & yes & yes & yes & yes & yes & yes & yes & yes \\
\hline N Obs & 46771 & 46778 & 46778 & 46778 & 38543 & 38550 & 38550 & 38550 & 38379 & 38386 & 38386 & 38386 \\
\hline $\mathrm{R} \mathrm{Sq}$ & 0.61 & 0.34 & 0.81 & 0.75 & 0.56 & 0.27 & 0.82 & 0.73 & 0.52 & 0.27 & 0.59 & 0.65 \\
\hline
\end{tabular}
measles, yellow fever, poliomyelitis and DTP, without the last two and with DT for adults), and public education infrastructure (number of schools and teachers - primary and secondary - per capita). 
Table 3: Mortality Effect of PSF by Age Group and Geographic Region, Brazilian Municipalities, 1995-2003

\begin{tabular}{|c|c|c|c|c|c|c|c|c|c|c|}
\hline & \multicolumn{5}{|c|}{ Mortality before 1} & \multicolumn{5}{|c|}{ Mortality between 1 and 4} \\
\hline & North & Northeast & Southeast & South & Center-West & North & Northeast & Southeast & South & Center-West \\
\hline Program Year 1 & $\begin{array}{c}0.6614 \\
(0.8555)\end{array}$ & $\begin{array}{c}-2.0970^{* * *} \\
(0.6069)\end{array}$ & $\begin{array}{c}0.1669 \\
(0.3159)\end{array}$ & $\begin{array}{c}0.4802 \\
(0.4210)\end{array}$ & $\begin{array}{l}-0.0461 \\
(0.5543)\end{array}$ & $\begin{array}{l}-0.0010 \\
(0.0618)\end{array}$ & $\begin{array}{c}-0.0567^{*} \\
(0.0328)\end{array}$ & $\begin{array}{c}-0.0218 \\
(0.0179)\end{array}$ & $\begin{array}{c}-0.0280 \\
(0.0368)\end{array}$ & $\begin{array}{c}0.0128 \\
(0.0645)\end{array}$ \\
\hline Program Year 2 & $\begin{array}{c}0.3423 \\
(1.0352)\end{array}$ & $\begin{array}{c}-3.0674 * * * \\
(0.8445)\end{array}$ & $\begin{array}{c}0.5253 \\
(0.3205)\end{array}$ & $\begin{array}{c}0.7267 \\
(0.5386)\end{array}$ & $\begin{array}{l}-1.1315 \\
(1.1217)\end{array}$ & $\begin{array}{c}0.0636 \\
(0.0764)\end{array}$ & $\begin{array}{c}-0.1225^{* * *} \\
(0.0370)\end{array}$ & $\begin{array}{l}-0.0155 \\
(0.0211)\end{array}$ & $\begin{array}{c}-0.0668^{*} \\
(0.0387)\end{array}$ & $\begin{array}{c}0.0606 \\
(0.0847)\end{array}$ \\
\hline Program Year 3 & $\begin{array}{c}-2.7711^{* *} \\
(1.3771)\end{array}$ & $\begin{array}{c}-5.1062 * * * \\
(1.1782)\end{array}$ & $\begin{array}{c}0.1644 \\
(0.4619)\end{array}$ & $\begin{array}{c}0.4099 \\
(0.5876)\end{array}$ & $\begin{array}{l}-1.9049 \\
(1.7159)\end{array}$ & $\begin{array}{l}-0.1151 \\
(0.0971)\end{array}$ & $\begin{array}{c}-0.1620^{* * *} \\
(0.0496)\end{array}$ & $\begin{array}{l}-0.0190 \\
(0.0288)\end{array}$ & $\begin{array}{c}-0.0590 \\
(0.0405)\end{array}$ & $\begin{array}{c}0.0341 \\
(0.1207)\end{array}$ \\
\hline Program Year 4 & $\begin{array}{c}-5.3465^{* * *} \\
(1.7341)\end{array}$ & $\begin{array}{c}-7.1291^{* * *} \\
(1.8925)\end{array}$ & $\begin{array}{c}0.2656 \\
(0.5897)\end{array}$ & $\begin{array}{c}0.2739 \\
(0.7630)\end{array}$ & $\begin{array}{l}-1.8297 \\
(2.3510)\end{array}$ & $\begin{array}{c}-0.2012^{*} \\
(0.1123)\end{array}$ & $\begin{array}{c}-0.2484^{* * *} \\
(0.0727)\end{array}$ & $\begin{array}{c}-0.0534 * \\
(0.0280)\end{array}$ & $\begin{array}{c}-0.0175 \\
(0.0504)\end{array}$ & $\begin{array}{l}-0.0044 \\
(0.1418)\end{array}$ \\
\hline Program Year 5 & $\begin{array}{c}-8.7942^{* * *} \\
(2.6323)\end{array}$ & $\begin{array}{c}-8.3549 * * * \\
(2.3365)\end{array}$ & $\begin{array}{l}-0.0207 \\
(0.7784)\end{array}$ & $\begin{array}{c}-0.1699 \\
(0.7137)\end{array}$ & $\begin{array}{l}-4.8848 \\
(3.2330)\end{array}$ & $\begin{array}{c}-0.4263^{* * *} \\
(0.1591)\end{array}$ & $\begin{array}{c}-0.3378 * * * \\
(0.0970)\end{array}$ & $\begin{array}{l}-0.0307 \\
(0.0370)\end{array}$ & $\begin{array}{c}-0.0802 \\
(0.0500)\end{array}$ & $\begin{array}{l}-0.0341 \\
(0.1920)\end{array}$ \\
\hline Program Year 6 & $\begin{array}{c}-12.6763^{* * * *} \\
(3.7045)\end{array}$ & $\begin{array}{c}-10.9172 * * * \\
(3.1196)\end{array}$ & $\begin{array}{c}0.0482 \\
(0.9172)\end{array}$ & $\begin{array}{l}-0.2554 \\
(0.8955)\end{array}$ & $\begin{array}{l}-5.7943 * \\
(3.1028)\end{array}$ & $\begin{array}{c}-0.6450^{* * *} \\
(0.1811)\end{array}$ & $\begin{array}{c}-0.4393^{* * *} \\
(0.1048)\end{array}$ & $\begin{array}{c}-0.0641^{*} \\
(0.0387)\end{array}$ & $\begin{array}{c}-0.0947 \\
(0.0627)\end{array}$ & $\begin{array}{l}-0.1750 \\
(0.2244)\end{array}$ \\
\hline Program Year 7 & $\begin{array}{c}-12.7825^{* *} \\
(5.4328)\end{array}$ & $\begin{array}{c}-10.9113^{* * *} \\
(3.7662)\end{array}$ & $\begin{array}{c}0.5394 \\
(1.1476)\end{array}$ & $\begin{array}{c}-0.3188 \\
(1.1068)\end{array}$ & $\begin{array}{c}-10.2979 * * \\
(4.2799)\end{array}$ & $\begin{array}{l}-0.2939 \\
(0.2903)\end{array}$ & $\begin{array}{c}-0.4862^{* * *} \\
(0.1334)\end{array}$ & $\begin{array}{l}-0.0331 \\
(0.0527)\end{array}$ & $\begin{array}{c}-0.1026 \\
(0.0733)\end{array}$ & $\begin{array}{l}-0.2881 \\
(0.2820)\end{array}$ \\
\hline Program Year 8 & $\begin{array}{c}-14.9974 * * * \\
(4.9848) \\
\end{array}$ & $\begin{array}{c}-13.8228^{* * *} \\
(4.5430) \\
\end{array}$ & $\begin{array}{l}-0.7853 \\
(1.3497) \\
\end{array}$ & $\begin{array}{c}0.7429 \\
(1.6491) \\
\end{array}$ & & $\begin{array}{l}-0.3850 \\
(0.4827) \\
\end{array}$ & $\begin{array}{c}-0.5465 * * * \\
(0.1333) \\
\end{array}$ & $\begin{array}{l}-0.0720 \\
(0.0737) \\
\end{array}$ & $\begin{array}{c}-0.2562^{* *} \\
(0.1219) \\
\end{array}$ & \\
\hline $\begin{array}{l}\mathrm{N} \text { Obs } \\
\mathrm{RS} \mathrm{Sa}\end{array}$ & $\begin{array}{l}3436 \\
0.71\end{array}$ & $\begin{array}{c}14021 \\
0.63\end{array}$ & $\begin{array}{c}12272 \\
0.61\end{array}$ & $\begin{array}{l}9439 \\
0.45\end{array}$ & $\begin{array}{l}3756 \\
0.49\end{array}$ & $\begin{array}{l}3436 \\
0.41\end{array}$ & $\begin{array}{c}14021 \\
0.40\end{array}$ & $\begin{array}{c}12279 \\
0.27\end{array}$ & $\begin{array}{l}9439 \\
0.20\end{array}$ & $\begin{array}{l}3756 \\
0.32\end{array}$ \\
\hline \multirow{2}{*}{$\mathrm{R} \mathrm{Sq}$} & \multicolumn{5}{|c|}{ Mortality between 15 and 59} & \multicolumn{5}{|c|}{ Mortality above 59} \\
\hline & North & Northeast & Southeast & South & Center-West & North & Northeast & Southeast & South & Center-West \\
\hline Program Year 1 & $\begin{array}{c}0.0601 \\
(0.0615)\end{array}$ & $\begin{array}{c}-0.0911^{* *} \\
(0.0386)\end{array}$ & $\begin{array}{l}-0.0138 \\
(0.0306)\end{array}$ & $\begin{array}{c}0.0209 \\
(0.0290)\end{array}$ & $\begin{array}{c}0.0287 \\
(0.0615)\end{array}$ & $\begin{array}{l}1.2565^{*} \\
(0.6695)\end{array}$ & $\begin{array}{l}-0.5510 \\
(0.4133)\end{array}$ & $\begin{array}{c}0.0991 \\
(0.2096)\end{array}$ & $\begin{array}{c}0.2266 \\
(0.3004)\end{array}$ & $\begin{array}{l}-0.3658 \\
(0.7128)\end{array}$ \\
\hline Program Year 2 & $\begin{array}{c}-0.0528 \\
(0.0937)\end{array}$ & $\begin{array}{c}-0.1557 * * * \\
(0.0452)\end{array}$ & $\begin{array}{l}-0.0434 \\
(0.0265)\end{array}$ & $\begin{array}{c}0.0157 \\
(0.0307)\end{array}$ & $\begin{array}{c}0.0026 \\
(0.0785)\end{array}$ & $\begin{array}{l}-0.2253 \\
(0.8936)\end{array}$ & $\begin{array}{c}-1.2913^{* * *} \\
(0.4653)\end{array}$ & $\begin{array}{c}0.1821 \\
(0.2729)\end{array}$ & $\begin{array}{c}0.4922 \\
(0.3469)\end{array}$ & $\begin{array}{l}-0.7290 \\
(0.8341)\end{array}$ \\
\hline Program Year 3 & $\begin{array}{c}-0.1464 \\
(0.1155)\end{array}$ & $\begin{array}{c}-0.1866 * * * \\
(0.0599)\end{array}$ & $\begin{array}{c}-0.0843^{* *} \\
(0.0343)\end{array}$ & $\begin{array}{c}0.0210 \\
(0.0355)\end{array}$ & $\begin{array}{c}-0.1846 * \\
(0.1009)\end{array}$ & $\begin{array}{l}-1.5530 \\
(1.1085)\end{array}$ & $\begin{array}{c}-1.6477^{* * *} \\
(0.5563)\end{array}$ & $\begin{array}{c}0.0646 \\
(0.2618)\end{array}$ & $\begin{array}{c}0.6008 \\
(0.3802)\end{array}$ & $\begin{array}{l}-2.3149 \\
(1.4058)\end{array}$ \\
\hline Program Year 4 & $\begin{array}{c}-0.3032^{* *} \\
(0.1328)\end{array}$ & $\begin{array}{c}-0.2920^{* * *} \\
(0.0944)\end{array}$ & $\begin{array}{c}-0.0854^{* *} \\
(0.0390)\end{array}$ & $\begin{array}{l}-0.0152 \\
(0.0473)\end{array}$ & $\begin{array}{l}-0.2421 \\
(0.1616)\end{array}$ & $\begin{array}{c}-2.4192^{* *} \\
(1.1451)\end{array}$ & $\begin{array}{c}-2.9310^{* * *} \\
(0.9767)\end{array}$ & $\begin{array}{c}0.2569 \\
(0.2866)\end{array}$ & $\begin{array}{c}0.9042^{* *} \\
(0.4317)\end{array}$ & $\begin{array}{c}-3.5137 * * * \\
(1.2847)\end{array}$ \\
\hline Program Year 5 & $\begin{array}{c}-0.4467 * * * \\
(0.1588)\end{array}$ & $\begin{array}{c}-0.3385^{* * *} \\
(0.1088)\end{array}$ & $\begin{array}{c}-0.0947^{*} \\
(0.0565)\end{array}$ & $\begin{array}{c}0.0086 \\
(0.0571)\end{array}$ & $\begin{array}{l}-0.3748^{*} \\
(0.2132)\end{array}$ & $\begin{array}{c}-4.3822^{* * *} \\
(1.3944)\end{array}$ & $\begin{array}{c}-3.1603 * * * \\
(1.0131)\end{array}$ & $\begin{array}{c}0.4530 \\
(0.3642)\end{array}$ & $\begin{array}{c}0.3205 \\
(0.5019)\end{array}$ & $\begin{array}{c}-3.6781^{* *} \\
(1.5535)\end{array}$ \\
\hline Program Year 6 & $\begin{array}{c}-0.6123^{* * *} \\
(0.1738)\end{array}$ & $\begin{array}{c}-0.4003^{* * *} \\
(0.1445)\end{array}$ & $\begin{array}{c}-0.1453^{* *} \\
(0.0662)\end{array}$ & $\begin{array}{c}-0.0206 \\
(0.0645)\end{array}$ & $\begin{array}{c}-0.5198^{* *} \\
(0.2102)\end{array}$ & $\begin{array}{c}-4.7981^{* *} \\
(1.9348)\end{array}$ & $\begin{array}{c}-3.2521^{* *} \\
(1.3140)\end{array}$ & $\begin{array}{c}0.5509 \\
(0.4109)\end{array}$ & $\begin{array}{c}0.6669 \\
(0.7781)\end{array}$ & $\begin{array}{c}-6.7375^{* * *} \\
(1.7915)\end{array}$ \\
\hline Program Year 7 & $\begin{array}{c}-0.9682^{* * *} \\
(0.3246)\end{array}$ & $\begin{array}{c}-0.5037^{* * *} \\
(0.1784)\end{array}$ & $\begin{array}{l}-0.0577 \\
(0.0822)\end{array}$ & $\begin{array}{c}0.0816 \\
(0.0630)\end{array}$ & $\begin{array}{c}-0.6049^{* *} \\
(0.2720)\end{array}$ & $\begin{array}{l}-4.8187 \\
(3.9731)\end{array}$ & $\begin{array}{c}-4.5100^{* * *} \\
(1.6616)\end{array}$ & $\begin{array}{l}1.2906 * \\
(0.6685)\end{array}$ & $\begin{array}{c}0.4730 \\
(0.9301)\end{array}$ & $\begin{array}{c}-4.7583^{*} \\
(2.5538)\end{array}$ \\
\hline Program Year 8 & $\begin{array}{c}-0.9655^{* * *} \\
(0.3114) \\
\end{array}$ & $\begin{array}{c}-0.5898^{* * *} \\
(0.2044) \\
\end{array}$ & $\begin{array}{l}-0.1188 \\
(0.0925) \\
\end{array}$ & $\begin{array}{l}-0.0188 \\
(0.0786) \\
\end{array}$ & & $\begin{array}{r}-5.3666 \\
(4.1192) \\
\end{array}$ & $\begin{array}{c}-4.9774^{* * *} \\
(1.9199) \\
\end{array}$ & $\begin{array}{c}1.2654 \\
(0.9774) \\
\end{array}$ & $\begin{array}{c}0.8350 \\
(1.0922) \\
\end{array}$ & \\
\hline N Obs & 3436 & 14021 & 12279 & 9439 & 3756 & 3436 & 14021 & 12279 & 9439 & 3756 \\
\hline $\mathrm{R} \mathrm{Sq}$ & 0.75 & 0.77 & 0.80 & 0.61 & 0.52 & 0.79 & 0.71 & 0.67 & 0.50 & 0.64 \\
\hline
\end{tabular}

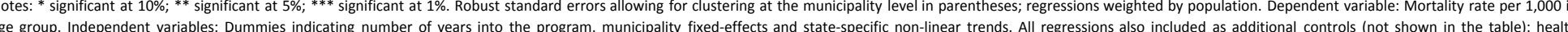
infrastructure (hospital beds and hospitals per capita), immunization rates (BCG, measles, yellow fever, poliomyelitis and DTP, without the last two and with DT for adults), and public education infrastructure (number of schools and teachers primary and secondary - per capita). 
Table 4: Mortality Effect of PSF by Age Group and Initial Mortality Quartile, Brazilian Municipalities, 1995-2003

\begin{tabular}{|c|c|c|c|c|c|c|c|c|c|c|}
\hline & \multicolumn{5}{|c|}{ Mortality before 1} & \multicolumn{5}{|c|}{ Mortality between 1 and 4} \\
\hline & Decile 6 & Decile 7 & Decile 8 & Decile 9 & Decile 10 & Decile 6 & Decile 7 & Decile 8 & Decile 9 & Decile 10 \\
\hline \multirow[t]{2}{*}{ Program Year 1} & 0.0476 & $1.0674^{* *}$ & 0.5683 & -0.7539 & -1.5285 & $-0.0921^{* *}$ & 0.0002 & -0.0248 & 0.0238 & -0.0459 \\
\hline & $(0.5021)$ & $(0.4791)$ & $(0.4059)$ & $(0.6049)$ & $(1.0706)$ & $(0.0377)$ & $(0.0267)$ & $(0.0354)$ & $(0.0495)$ & $(0.0916)$ \\
\hline \multirow[t]{2}{*}{ Program Year 2} & 0.5981 & 0.5913 & $0.9002 * *$ & -0.7279 & $-3.3608 * * *$ & -0.0616 & 0.0060 & -0.0372 & 0.0309 & -0.1174 \\
\hline & (0.5703) & $(0.5436)$ & $(0.4037)$ & $(0.8615)$ & $(1.2902)$ & $(0.0388)$ & $(0.0258)$ & $(0.0397)$ & $(0.0584)$ & (0.1037) \\
\hline \multirow[t]{2}{*}{ Program Year 3} & 0.2325 & $1.3026^{*}$ & -0.4690 & -1.1431 & $-4.8144 * * *$ & -0.0299 & 0.0295 & -0.0304 & -0.0650 & -0.0354 \\
\hline & (0.6649) & $(0.6720)$ & $(0.6266)$ & $(1.0427)$ & $(1.5510)$ & $(0.0445)$ & $(0.0363)$ & $(0.0448)$ & $(0.0712)$ & $(0.1414)$ \\
\hline \multirow[t]{2}{*}{ Program Year 4} & -0.8382 & 0.6644 & 0.1960 & -1.1540 & $-5.6711 * * *$ & -0.0782 & 0.0082 & -0.0343 & -0.1151 & -0.0384 \\
\hline & $(0.7714)$ & $(0.7967)$ & $(0.6834)$ & $(1.4353)$ & $(2.0093)$ & $(0.0504)$ & $(0.0374)$ & $(0.0560)$ & $(0.0811)$ & $(0.1675)$ \\
\hline \multirow[t]{2}{*}{ Program Year 5} & $-1.3120^{*}$ & 0.8525 & 0.5005 & -2.1445 & $-5.9787^{* *}$ & $-0.1153 * *$ & 0.0147 & -0.0140 & $-0.1891 *$ & -0.1409 \\
\hline & $(0.7557)$ & $(1.0013)$ & $(0.8653)$ & (1.5989) & $(2.4508)$ & $(0.0568)$ & $(0.0475)$ & $(0.0680)$ & $(0.0969)$ & (0.1968) \\
\hline Program Year 6 & $\begin{array}{l}-0.8873 \\
(0.9139)\end{array}$ & $\begin{array}{c}0.7948 \\
(1.1757)\end{array}$ & $\begin{array}{c}0.0397 \\
(0.9587)\end{array}$ & $\begin{array}{l}-2.5684 \\
(1.8636)\end{array}$ & $\begin{array}{c}-7.5306^{* * *} \\
(2.8689)\end{array}$ & $\begin{array}{c}-0.1829 * * \\
(0.0753)\end{array}$ & $\begin{array}{c}-0.0822 \\
(0.0520)\end{array}$ & $\begin{array}{c}-0.0556 \\
(0.0713)\end{array}$ & $\begin{array}{l}-0.1580 \\
(01161)\end{array}$ & $\begin{array}{l}-0.0838 \\
(02409)\end{array}$ \\
\hline \multirow{2}{*}{ Program Year 7} & -0.1967 & 1.8045 & 0.8062 & -1.8653 & $-6.3280^{*}$ & $-0.1744^{*}$ & -0.0402 & $\begin{array}{l}-0.1496 \\
-0.13)\end{array}$ & $\begin{array}{l}(0.1101) \\
0.0140\end{array}$ & $\begin{array}{l}0.24091 \\
-0.0979\end{array}$ \\
\hline & (1.2841) & $(2.6923)$ & (1.7509) & (2.3309) & (3.5955) & $(0.0945)$ & (0.0759) & $(0.0962)$ & $(0.1481)$ & $(0.3209)$ \\
\hline \multirow[t]{2}{*}{ Program Year 8} & -1.0834 & 0.5369 & -0.4168 & -1.9495 & -7.0096 & -0.1875 & -0.1275 & -0.0919 & -0.0297 & -0.0837 \\
\hline & (1.4082) & $(3.9469)$ & (1.9275) & $(2.6311)$ & $(4.3773)$ & $(0.1220)$ & $(0.1160)$ & $(0.1071)$ & (0.1694) & $(0.3366)$ \\
\hline N Obs & 4351 & 4244 & 4204 & 4197 & 4313 & 4314 & 4287 & 4271 & 4261 & 4258 \\
\hline \multirow[t]{3}{*}{$\mathrm{RSq}$} & 0.50 & 0.57 & 0.64 & 0.67 & 0.68 & 0.37 & 0.44 & 0.41 & 0.43 & 0.42 \\
\hline & \multicolumn{5}{|c|}{ Mortality between 15 and 59} & \multicolumn{5}{|c|}{ Mortality above 59} \\
\hline & Decile 6 & Decile 7 & Decile 8 & Decile 9 & Decile 10 & Decile 6 & Decile 7 & Decile 8 & Decile 9 & Decile 10 \\
\hline \multirow[t]{2}{*}{ Program Year 1} & 0.0525 & -0.0732 & 0.0002 & 0.0107 & -0.0350 & 0.7304 & $0.5421^{*}$ & 0.1127 & -0.0152 & 0.1076 \\
\hline & $(0.0631)$ & $(0.0465)$ & $(0.0368)$ & $(0.0281)$ & $(0.0349)$ & (0.4809) & $(0.3121)$ & $(0.3157)$ & $(0.3336)$ & $(0.5053)$ \\
\hline \multirow[t]{2}{*}{ Program Year 2} & 0.0556 & -0.0085 & 0.0411 & -0.0017 & -0.0682 & 0.2689 & -0.1061 & 0.5027 & -0.0878 & -0.2098 \\
\hline & $(0.0629)$ & $(0.0440)$ & $(0.0513)$ & $(0.0318)$ & $(0.0499)$ & $(0.5675)$ & $(0.3023)$ & $(0.6064)$ & $(0.3893)$ & $(0.6062)$ \\
\hline \multirow[t]{2}{*}{ Program Year 3} & 0.0877 & -0.0840 & 0.0004 & -0.0438 & -0.1073 & $1.3685^{*}$ & 0.0037 & -0.4841 & -0.0024 & 0.2781 \\
\hline & $(0.0727)$ & $(0.0583)$ & $(0.0484)$ & $(0.0475)$ & $(0.0722)$ & $(0.7906)$ & $(0.4437)$ & $(0.4200)$ & $(0.4553)$ & $(0.7183)$ \\
\hline \multirow[t]{2}{*}{ Program Year 4} & 0.0393 & -0.0323 & -0.0341 & $-0.1633^{* * *}$ & -0.0184 & 0.9380 & -0.2692 & 0.0741 & 0.0375 & -0.1377 \\
\hline & (0.0788) & $(0.0652)$ & $(0.0640)$ & (0.0488) & $(0.0805)$ & $(0.9303)$ & $(0.5075)$ & $(0.5410)$ & $(0.4950)$ & $(0.8025)$ \\
\hline \multirow[t]{2}{*}{ Program Year 5} & 0.0588 & -0.1369 & -0.0422 & $-0.1238^{*}$ & -0.0031 & 0.6841 & 0.1921 & 0.0494 & 0.4766 & 0.7280 \\
\hline & $(0.0906)$ & $(0.0835)$ & $(0.0842)$ & $(0.0684)$ & (0.1078) & (1.1535) & $(0.5065)$ & $(0.6735)$ & $(0.6430)$ & (0.9548) \\
\hline \multirow[t]{2}{*}{ Program Year 6} & 0.0569 & $-0.1708^{*}$ & 0.0009 & $-0.2414^{* * *}$ & -0.0725 & 0.1971 & 0.4456 & 0.1622 & 0.7804 & -0.2669 \\
\hline & $(0.1172)$ & $(0.0943)$ & $(0.1054)$ & $(0.0637)$ & $(0.1201)$ & $(1.2991)$ & $(0.5756)$ & $(0.7556)$ & $(0.7390)$ & (1.2110) \\
\hline \multirow[t]{2}{*}{ Program Year 7} & 0.1039 & 0.0293 & 0.0061 & -0.1068 & -0.0121 & -0.0131 & -0.5589 & 1.3230 & $1.8826 * *$ & -0.5874 \\
\hline & $(0.1961)$ & $(0.1052)$ & (0.1939) & $(0.1044)$ & $(0.1223)$ & $(1.4263)$ & $(1.0793)$ & $(0.8501)$ & (0.9094) & (2.0668) \\
\hline \multirow[t]{2}{*}{ Program Year 8} & 0.1344 & -0.1944 & 0.0385 & -0.1427 & -0.0992 & 0.0312 & 1.0576 & $1.8211^{*}$ & 1.3110 & -1.6554 \\
\hline & $(0.2485)$ & $(0.1399)$ & $(0.2407)$ & $(0.1014)$ & $(0.1478)$ & $(1.6516)$ & $(1.2925)$ & $(1.0380)$ & $(1.1280)$ & $(2.0198)$ \\
\hline N Obs & 4261 & 4260 & 4257 & 4181 & 4202 & 4272 & 4270 & 4257 & 4256 & 4258 \\
\hline $\mathrm{R} \mathrm{Sq}$ & 0.57 & 0.60 & 0.66 & 0.74 & 0.80 & 0.62 & 0.67 & 0.66 & 0.64 & 0.74 \\
\hline
\end{tabular}


Table 5: Mortality Effect of PSF by Age Group and Percentage of Urban Population in 1991, Brazilian Municipalities, 1995-2003

\begin{tabular}{|c|c|c|c|c|c|c|c|c|}
\hline \multirow[b]{3}{*}{ Progr } & \multicolumn{4}{|c|}{ Mortality before 1} & \multicolumn{4}{|c|}{$\begin{array}{l}\text { Mortality between } 1 \text { and } 4 \\
\text { twn } 25 \% \text { and Btwn } 50 \% \text { and }\end{array}$} \\
\hline & Below 25\% & $50 \%$ & $75 \%$ & Above $75 \%$ & Below 25\% & $50 \%$ & $75 \%$ & Above $75 \%$ \\
\hline & $\begin{array}{c}0.6698 \\
(0.8403)\end{array}$ & $\begin{array}{c}0.4949 \\
(0.5008)\end{array}$ & $\begin{array}{l}-0.2686 \\
(0.6056)\end{array}$ & $\begin{array}{c}0.4289 \\
(0.2969)\end{array}$ & $\begin{array}{c}0.0320 \\
(0.0677)\end{array}$ & $\begin{array}{c}0.0300 \\
(0.0398)\end{array}$ & $\begin{array}{l}-0.0043 \\
(0.0428)\end{array}$ & $\begin{array}{l}-0.0266 \\
(0.0183)\end{array}$ \\
\hline Program Year 2 & $\begin{array}{c}0.7827 \\
(0.9842)\end{array}$ & $\begin{array}{l}-0.3329 \\
(0.7385)\end{array}$ & $\begin{array}{c}0.3056 \\
(0.7741)\end{array}$ & $\begin{array}{c}0.3206 \\
(0.3224)\end{array}$ & $\begin{array}{c}0.0345 \\
(0.0926)\end{array}$ & $\begin{array}{l}-0.0035 \\
(0.0475)\end{array}$ & $\begin{array}{l}-0.0060 \\
(0.0530)\end{array}$ & $\begin{array}{l}-0.0376 * \\
(0.0198)\end{array}$ \\
\hline Program Year 3 & $\begin{array}{l}-1.5460 \\
(1.2478)\end{array}$ & $\begin{aligned}-1.9072^{*} \\
(1.0284)\end{aligned}$ & $\begin{array}{l}-1.2044 \\
(0.8996)\end{array}$ & $\begin{array}{l}-0.0069 \\
(0.4122)\end{array}$ & $\begin{array}{l}-0.1088 \\
(0.1009)\end{array}$ & $\begin{array}{c}0.0174 \\
(0.0592)\end{array}$ & $\begin{array}{l}-0.0216 \\
(0.0635)\end{array}$ & $\begin{array}{l}-0.0384 \\
(0.0260)\end{array}$ \\
\hline Program Year 4 & $\begin{array}{l}-2.1196 \\
(1.5400)\end{array}$ & $\begin{array}{c}-3.5066^{* *} \\
(1.5067)\end{array}$ & $\begin{array}{l}-1.1873 \\
(1.1222)\end{array}$ & $\begin{array}{l}-0.1761 \\
(0.5489)\end{array}$ & $\begin{array}{c}-0.3362^{* * *} \\
(0.1187)\end{array}$ & $\begin{array}{l}-0.0979 \\
(0.0767)\end{array}$ & $\begin{array}{l}-0.0570 \\
(0.0739)\end{array}$ & $\begin{array}{l}-0.0518^{*} \\
(0.0278)\end{array}$ \\
\hline Program Year 5 & $\begin{array}{l}-1.3819 \\
(2.1430)\end{array}$ & $\begin{array}{c}-4.7363^{* * *} \\
(1.8314)\end{array}$ & $\begin{array}{l}-1.0333 \\
(1.5951)\end{array}$ & $\begin{array}{l}-0.6285 \\
(0.6708)\end{array}$ & $\begin{array}{l}-0.2227 \\
(0.1676)\end{array}$ & $\begin{array}{l}-0.1582^{*} \\
(0.0881)\end{array}$ & $\begin{array}{l}-0.1028 \\
(0.0948)\end{array}$ & $\begin{array}{c}-0.0835^{* *} \\
(0.0338)\end{array}$ \\
\hline Program Year 6 & $\begin{array}{l}-2.1375 \\
(2.8177)\end{array}$ & $\begin{array}{c}-7.4179 * * * \\
(2.7374)\end{array}$ & $\begin{array}{l}-1.5418 \\
(2.1232)\end{array}$ & $\begin{array}{l}-0.7296 \\
(0.7942)\end{array}$ & $\begin{array}{c}-0.5275^{* *} \\
(0.2118)\end{array}$ & $\begin{array}{l}-0.1903^{*} \\
(0.1109)\end{array}$ & $\begin{array}{c}-0.2551^{* *} \\
(0.1085)\end{array}$ & $\begin{array}{c}-0.1015^{* * *} \\
(0.0369)\end{array}$ \\
\hline Program Year 7 & $\begin{array}{l}-1.7480 \\
(3.7192)\end{array}$ & $\begin{array}{c}-7.7671^{* *} \\
(3.6769)\end{array}$ & $\begin{array}{c}2.7737 \\
(3.3661)\end{array}$ & $\begin{array}{l}-0.8142 \\
(1.0595)\end{array}$ & $\begin{array}{l}-0.2067 \\
(0.2785)\end{array}$ & $\begin{array}{l}-0.2243 \\
(0.1495)\end{array}$ & $\begin{array}{l}-0.1364 \\
(0.1538)\end{array}$ & $\begin{array}{c}-0.1147^{* *} \\
(0.0492)\end{array}$ \\
\hline Program Year 8 & $\begin{array}{l}-2.9073 \\
(3.7936) \\
\end{array}$ & $\begin{array}{c}-11.2441 * * \\
(4.8220) \\
\end{array}$ & $\begin{array}{c}3.8161 \\
(4.5254) \\
\end{array}$ & $\begin{array}{l}-1.6003 \\
(1.2486) \\
\end{array}$ & $\begin{array}{r}-0.4482 \\
(0.2912) \\
\end{array}$ & $\begin{array}{l}-0.2862 * \\
(0.1551) \\
\end{array}$ & $\begin{array}{c}0.2161 \\
(0.1808) \\
\end{array}$ & $\begin{array}{c}-0.2155^{* * *} \\
(0.0638)\end{array}$ \\
\hline $\begin{array}{l}\mathrm{N} \text { Obs } \\
\mathrm{R} \mathrm{Sq}\end{array}$ & $\begin{array}{l}4824 \\
0.56 \\
\end{array}$ & $\begin{array}{c}13792 \\
0.57 \\
\end{array}$ & $\begin{array}{c}11912 \\
0.60\end{array}$ & $\begin{array}{l}8234 \\
0.77 \\
\end{array}$ & $\begin{array}{l}4824 \\
0.33 \\
\end{array}$ & $\begin{array}{c}13792 \\
0.33 \\
\end{array}$ & $\begin{array}{c}11919 \\
0.36 \\
\end{array}$ & $\begin{array}{l}8234 \\
0.49 \\
\end{array}$ \\
\hline \multirow{2}{*}{$\mathrm{R} \mathrm{Sq}$} & \multicolumn{4}{|c|}{$\begin{array}{l}\text { Mortality between } 15 \text { and } 59 \\
\text { Btwn } 25 \% \text { and Btwn } 50 \% \text { and }\end{array}$} & \multicolumn{4}{|c|}{$\begin{array}{l}\text { Mortality above } 59 \\
\text { n 25\% and Btwn } 50 \% \text { and }\end{array}$} \\
\hline & Below 25\% & $50 \%$ & $75 \%$ & Above $75 \%$ & Below 25\% & $50 \%$ & $75 \%$ & Above $75 \%$ \\
\hline Program Year 1 & $\begin{array}{l}-0.0002 \\
(0.0539)\end{array}$ & $\begin{array}{l}-0.0195 \\
(0.0312)\end{array}$ & $\begin{array}{l}-0.0073 \\
(0.0334)\end{array}$ & $\begin{array}{c}0.0027 \\
(0.0245)\end{array}$ & $\begin{array}{l}0.7136 \\
(0.6340)\end{array}$ & $\begin{array}{l}0.0769 \\
(0.3425)\end{array}$ & $\begin{array}{l}0.2168 \\
(0.3049)\end{array}$ & $\begin{array}{l}0.3705^{*} \\
(0.2052)\end{array}$ \\
\hline Program Year 2 & $\begin{array}{c}0.0569 \\
(0.0753)\end{array}$ & $\begin{array}{l}-0.0245 \\
(0.0398)\end{array}$ & $\begin{array}{l}-0.0342 \\
(0.0371)\end{array}$ & $\begin{array}{l}-0.0268 \\
(0.0234)\end{array}$ & $\begin{array}{c}0.6537 \\
(0.7915)\end{array}$ & $\begin{array}{c}0.2897 \\
(0.4354)\end{array}$ & $\begin{array}{l}-0.5486 \\
(0.3780)\end{array}$ & $\begin{array}{c}0.2792 \\
(0.2380)\end{array}$ \\
\hline Program Year 3 & $\begin{array}{l}-0.0157 \\
(0.0793)\end{array}$ & $\begin{array}{l}-0.0850^{*} \\
(0.0480)\end{array}$ & $\begin{array}{l}-0.0389 \\
(0.0471)\end{array}$ & $\begin{array}{l}-0.0574^{*} \\
(0.0302)\end{array}$ & $\begin{array}{c}0.5305 \\
(1.0140)\end{array}$ & $\begin{array}{l}0.2422 \\
(0.5501)\end{array}$ & $\begin{array}{l}-0.5502 \\
(0.4551)\end{array}$ & $\begin{array}{l}0.1109 \\
(0.2551)\end{array}$ \\
\hline Program Year 4 & $\begin{array}{l}-0.1111 \\
(0.0994)\end{array}$ & $\begin{array}{c}-0.1366^{* *} \\
(0.0591)\end{array}$ & $\begin{array}{l}-0.1055^{*} \\
(0.0587)\end{array}$ & $\begin{array}{c}-0.0783^{* *} \\
(0.0350)\end{array}$ & $\begin{array}{c}0.5041 \\
(1.1928)\end{array}$ & $\begin{array}{l}-0.1236 \\
(0.6578)\end{array}$ & $\begin{array}{c}-1.2922^{* *} \\
(0.5103)\end{array}$ & $\begin{array}{c}0.1199 \\
(0.2933)\end{array}$ \\
\hline Program Year 5 & $\begin{array}{l}-0.1201 \\
(0.1230)\end{array}$ & $\begin{array}{l}-0.1204 \\
(0.0822)\end{array}$ & $\begin{array}{c}-0.1547^{* *} \\
(0.0759)\end{array}$ & $\begin{array}{l}-0.0759 \\
(0.0464)\end{array}$ & $\begin{array}{c}1.2095 \\
(1.5586)\end{array}$ & $\begin{array}{l}-0.4322 \\
(0.8992)\end{array}$ & $\begin{array}{c}-1.5901^{* *} \\
(0.6348)\end{array}$ & $\begin{array}{c}0.2541 \\
(0.3332)\end{array}$ \\
\hline Program Year 6 & $\begin{array}{l}-0.1067 \\
(0.1624)\end{array}$ & $\begin{array}{c}-0.2338^{* *} \\
(0.1110)\end{array}$ & $\begin{array}{c}-0.1807^{*} \\
(0.0945)\end{array}$ & $\begin{array}{c}-0.1269 * * \\
(0.0546)\end{array}$ & $\begin{array}{c}1.2205 \\
(1.7426)\end{array}$ & $\begin{array}{c}-0.8874 \\
(1.1963)\end{array}$ & $\begin{array}{c}-1.7280^{* *} \\
(0.7828)\end{array}$ & $\begin{array}{l}0.6477^{*} \\
(0.3841)\end{array}$ \\
\hline Program Year 7 & $\begin{array}{l}-0.0287 \\
(0.2439)\end{array}$ & $\begin{array}{c}-0.3344^{*} \\
(0.1775)\end{array}$ & $\begin{array}{c}-0.0317 \\
(0.1159)\end{array}$ & $\begin{array}{l}-0.0806 \\
(0.0677)\end{array}$ & $\begin{array}{c}0.1596 \\
(2.1771)\end{array}$ & $\begin{array}{l}-1.8820 \\
(1.9539)\end{array}$ & $\begin{array}{c}-0.8649 \\
(1.1333)\end{array}$ & $\begin{array}{c}0.5536 \\
(0.5949)\end{array}$ \\
\hline Program Year 8 & $\begin{array}{c}-0.6327^{*} \\
(0.3489) \\
\end{array}$ & $\begin{array}{c}-0.4097^{* *} \\
(0.1714) \\
\end{array}$ & $\begin{array}{c}-0.0892 \\
(0.1261) \\
\end{array}$ & $\begin{array}{c}-0.1494 * \\
(0.0786) \\
\end{array}$ & $\begin{array}{r}-3.3220 \\
(2.7322) \\
\end{array}$ & $\begin{array}{l}-1.4035 \\
(2.5050) \\
\end{array}$ & $\begin{array}{c}-1.4392 \\
(1.2589) \\
\end{array}$ & $\begin{array}{c}0.4092 \\
(0.7032) \\
\end{array}$ \\
\hline N Obs & 4824 & 13792 & 11919 & 8234 & 4824 & 13792 & 11919 & 8234 \\
\hline $\mathrm{RSq}$ & 0.66 & 0.63 & 0.62 & 0.86 & 0.71 & 0.66 & 0.66 & 0.69 \\
\hline
\end{tabular}

Notes: * significant at $10 \% ; * *$ significant at $5 \% ; * * *$ significant at $1 \%$. Robust standard errors allowing for clustering at the municipality level in parentheses; regressions weighted by population. All regressions also included as additional controls (not shown in the table): health infrastructure (hospital beds and hospitals per capita), immunization rates (BCG, measles, yellow fever, poliomyelitis and DTP, without the last two and with DT for adults), and public education infrastructure (number of schools and teachers - primary and secondary - per capita). 
Table 6: Mortality Effect of PSF by Age Group and Percentage of Households with Access to Treated Water in 1991, Brazilian Municipalities, 1995-2003

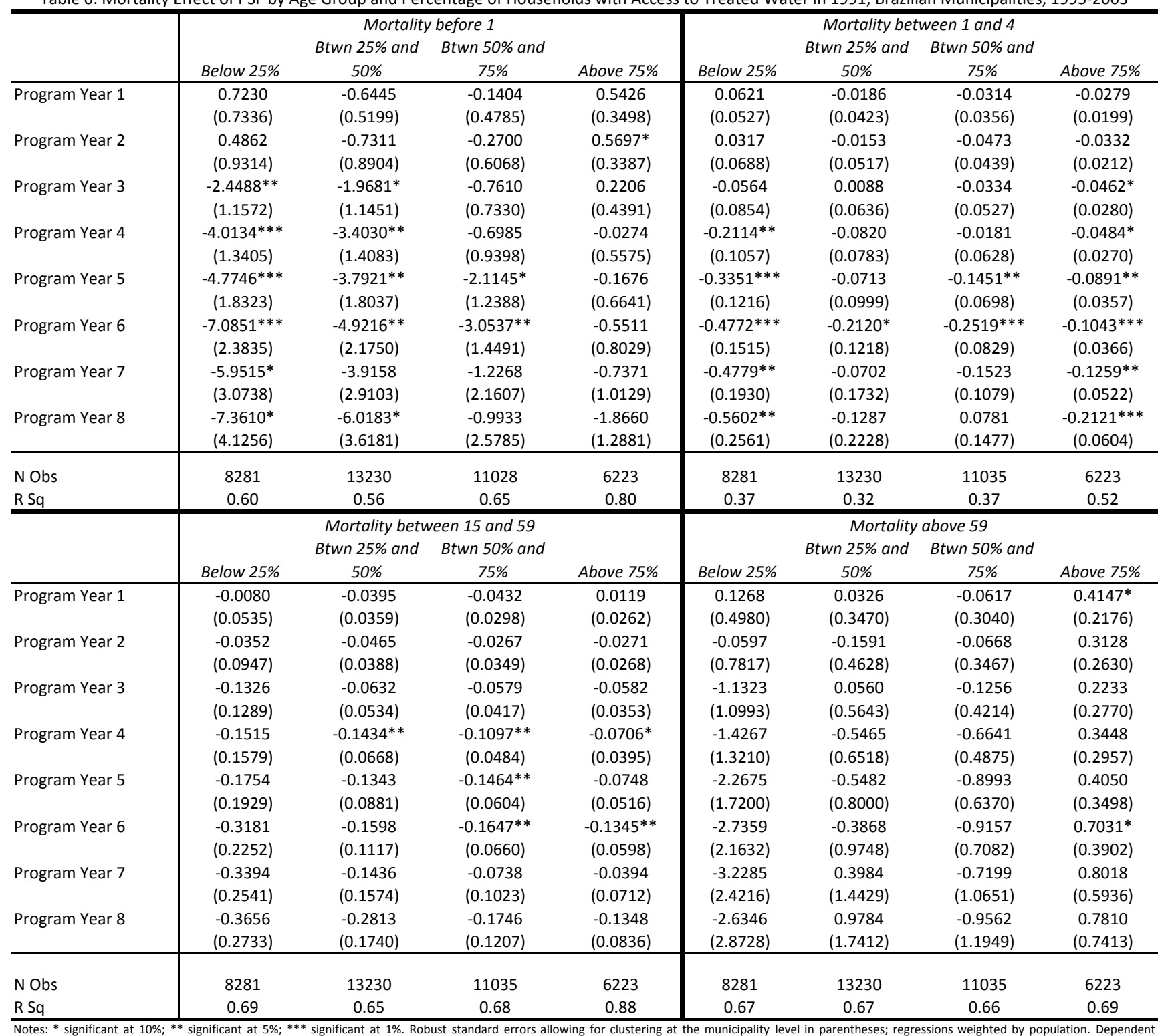

variable: Mortality rate per 1,000 in age group. Independent variables: Dummies indicating number of years into the program, municipality fixed-effects and state-specific non-linear trends. All regressions also included as additional controls (not shown in the table): health infrastructure (hospital beds and hospitals per capita), immunization rates (BCG, measles, yellow fever, poliomyelitis and DTP, without the last two and with DT for adults), and public education infrastructure (number of schools and teachers - primary and secondary - per capita). 
Table 7: Mortality Effect of PSF by Age Group and Percentage of Households with Toilet connected to the Public Sewer System in 1991, Brazilian Municipalities, 1995-2003

\begin{tabular}{|c|c|c|c|c|c|c|c|c|}
\hline & \multicolumn{4}{|c|}{ Mortality before 1} & \multicolumn{4}{|c|}{ Mortality between 1 and 4} \\
\hline & Below 25\% & Btwn $25 \%$ and $50 \%$ & Btwn $50 \%$ and $75 \%$ & Above $75 \%$ & Below 25\% & Btwn $25 \%$ and $50 \%$ & Btwn $50 \%$ and $75 \%$ & Above $75 \%$ \\
\hline Program Year 1 & $\begin{array}{c}-0.6876^{*} \\
(0.3840)\end{array}$ & $\begin{array}{c}0.8057 \\
(0.6848)\end{array}$ & $\begin{array}{l}-0.3848 \\
(0.5640)\end{array}$ & $\begin{array}{c}0.4540 \\
(0.4029)\end{array}$ & $\begin{array}{l}-0.0190 \\
(0.0226)\end{array}$ & $\begin{array}{c}0.0277 \\
(0.0479)\end{array}$ & $\begin{array}{c}-0.0887^{* * *} \\
(0.0316)\end{array}$ & $\begin{array}{c}-0.0488^{*} \\
(0.0266)\end{array}$ \\
\hline Program Year 2 & $\begin{array}{l}-0.6502 \\
(0.4882)\end{array}$ & $\begin{array}{l}-1.0127 \\
(0.6971)\end{array}$ & $\begin{array}{c}-0.3172 \\
(0.9283)\end{array}$ & $\begin{array}{c}0.3860 \\
(0.3212)\end{array}$ & $\begin{array}{l}-0.0290 \\
(0.0264)\end{array}$ & $\begin{array}{l}-0.0434 \\
(0.0540)\end{array}$ & $\begin{array}{l}-0.0179 \\
(0.0435)\end{array}$ & $\begin{array}{c}-0.0543^{* *} \\
(0.0219)\end{array}$ \\
\hline Program Year 3 & $\begin{array}{c}-2.0752^{* * *} \\
(0.6403)\end{array}$ & $\begin{array}{l}-0.5933 \\
(0.9486)\end{array}$ & $\begin{array}{l}-1.0554 \\
(1.0884)\end{array}$ & $\begin{array}{l}-0.3145 \\
(0.5266)\end{array}$ & $\begin{array}{c}-0.0750^{* *} \\
(0.0357)\end{array}$ & $\begin{array}{c}-0.0538 \\
(0.0579)\end{array}$ & $\begin{array}{c}-0.0462 \\
(0.0490)\end{array}$ & $\begin{array}{c}-0.0847^{* *} \\
(0.0423)\end{array}$ \\
\hline Program Year 4 & $\begin{array}{c}-3.1245^{* * *} \\
(0.9734)\end{array}$ & $\begin{array}{l}-1.6418 \\
(1.2337)\end{array}$ & $\begin{array}{c}-0.7884 \\
(1.6315)\end{array}$ & $\begin{array}{l}-0.6895 \\
(0.5920)\end{array}$ & $\begin{array}{c}-0.1186^{* * *} \\
(0.0450)\end{array}$ & $\begin{array}{c}-0.1656^{* *} \\
(0.0742)\end{array}$ & $\begin{array}{l}-0.0506 \\
(0.0505)\end{array}$ & $\begin{array}{c}-0.1144^{* * *} \\
(0.0324)\end{array}$ \\
\hline Program Year 5 & $\begin{array}{c}-4.4440^{* * *} \\
(1.2911)\end{array}$ & $\begin{array}{l}-0.4215 \\
(1.3647)\end{array}$ & $\begin{array}{l}-2.2174 \\
(2.0174)\end{array}$ & $\begin{array}{l}-1.1551 \\
(0.7341)\end{array}$ & $\begin{array}{c}-0.2243^{* * *} \\
(0.0662)\end{array}$ & $\begin{array}{c}-0.1698^{* *} \\
(0.0814)\end{array}$ & $\begin{array}{c}0.0047 \\
(0.0588)\end{array}$ & $\begin{array}{c}-0.1168 * * \\
(0.0467)\end{array}$ \\
\hline Program Year 6 & $\begin{array}{c}-6.2793 * * * \\
(1.7933)\end{array}$ & $\begin{array}{l}-1.8126 \\
(1.6023)\end{array}$ & $\begin{array}{l}-2.3258 \\
(2.4274)\end{array}$ & $\begin{array}{l}-1.2249 \\
(0.9463)\end{array}$ & $\begin{array}{c}-0.3276^{* * *} \\
(0.0763)\end{array}$ & $\begin{array}{c}-0.2030^{* *} \\
(0.0909)\end{array}$ & $\begin{array}{c}-0.1285^{*} \\
(0.0671)\end{array}$ & $\begin{array}{c}-0.1182^{* *} \\
(0.0496)\end{array}$ \\
\hline Program Year 7 & $\begin{array}{c}-5.1904^{* *} \\
(2.0208)\end{array}$ & $\begin{array}{l}-1.5949 \\
(1.7287)\end{array}$ & $\begin{array}{l}-2.3947 \\
(2.8184)\end{array}$ & $\begin{array}{l}-1.7390 \\
(1.7838)\end{array}$ & $\begin{array}{c}-0.3014^{* * *} \\
(0.0903)\end{array}$ & $\begin{array}{c}-0.2789^{* *} \\
(0.1158)\end{array}$ & $\begin{array}{c}0.0063 \\
(0.1084)\end{array}$ & $\begin{array}{l}-0.0991 \\
(0.0640)\end{array}$ \\
\hline Program Year 8 & $\begin{array}{c}-6.0814^{* *} \\
(2.5353) \\
\end{array}$ & $\begin{array}{l}-2.3097 \\
(2.4211) \\
\end{array}$ & $\begin{array}{l}-6.0595 \\
(3.7906) \\
\end{array}$ & $\begin{array}{c}-2.1165 \\
(1.7877) \\
\end{array}$ & $\begin{array}{c}-0.3329 * * * \\
(0.1069) \\
\end{array}$ & $\begin{array}{c}-0.3339 * * * \\
(0.1137)\end{array}$ & $\begin{array}{l}-0.0077 \\
(0.2616) \\
\end{array}$ & $\begin{array}{c}-0.1807 * \\
(0.0998) \\
\end{array}$ \\
\hline \multirow[t]{3}{*}{$\mathrm{R} \mathrm{Sq}$} & $\begin{array}{c}29599 \\
0.62\end{array}$ & $\begin{array}{c}3891 \\
0.68\end{array}$ & $\begin{array}{l}3375 \\
0.66\end{array}$ & $\begin{array}{l}1897 \\
0.76\end{array}$ & $\begin{array}{c}29599 \\
0.36\end{array}$ & $\begin{array}{l}3894 \\
0.35\end{array}$ & $\begin{array}{c}3379 \\
0.28\end{array}$ & $\begin{array}{l}1897 \\
0.39\end{array}$ \\
\hline & \multicolumn{4}{|c|}{ Mortality between 15 and 59} & \multicolumn{4}{|c|}{ Mortality above 59} \\
\hline & Below 25\% & Btwn $25 \%$ and $50 \%$ & Btwn $50 \%$ and $75 \%$ & Above $75 \%$ & Below 25\% & Btwn $25 \%$ and $50 \%$ & Btwn $50 \%$ and $75 \%$ & Above $75 \%$ \\
\hline Program Year 1 & $\begin{array}{l}-0.0286 \\
(0.0215)\end{array}$ & $\begin{array}{c}0.0003 \\
(0.0432)\end{array}$ & $\begin{array}{l}-0.0363 \\
(0.0391)\end{array}$ & $\begin{array}{l}-0.0015 \\
(0.0417)\end{array}$ & $\begin{array}{c}0.0665 \\
(0.2504)\end{array}$ & $\begin{array}{c}0.3744 \\
(0.5232)\end{array}$ & $\begin{array}{l}-0.5354 \\
(0.3509)\end{array}$ & $\begin{array}{c}0.2596 \\
(0.2748)\end{array}$ \\
\hline Program Year 2 & $\begin{array}{c}-0.0620 * * \\
(0.0269)\end{array}$ & $\begin{array}{l}-0.0110 \\
(0.0446)\end{array}$ & $\begin{array}{l}-0.0734 \\
(0.0577)\end{array}$ & $\begin{array}{l}-0.0346 \\
(0.0379)\end{array}$ & $\begin{array}{c}-0.3982 \\
(0.2978)\end{array}$ & $\begin{array}{c}0.3085 \\
(0.5188)\end{array}$ & $\begin{array}{l}-0.5845 \\
(0.4824)\end{array}$ & $\begin{array}{c}0.3326 \\
(0.4194)\end{array}$ \\
\hline Program Year 3 & $\begin{array}{c}-0.0870 * * \\
(0.0348)\end{array}$ & $\begin{array}{l}-0.0487 \\
(0.0561)\end{array}$ & $\begin{array}{l}-0.0519 \\
(0.0605)\end{array}$ & $\begin{array}{c}-0.1292^{* * *} \\
(0.0458)\end{array}$ & $\begin{array}{c}-0.6362 * \\
(0.3408)\end{array}$ & $\begin{array}{c}0.3414 \\
(0.6547)\end{array}$ & $\begin{array}{l}-0.7560 \\
(0.5346)\end{array}$ & $\begin{array}{c}0.2195 \\
(0.4057)\end{array}$ \\
\hline Program Year 4 & $\begin{array}{c}-0.1284^{* * *} \\
(0.0489)\end{array}$ & $\begin{array}{c}-0.1011 \\
(0.0734)\end{array}$ & $\begin{array}{l}-0.0175 \\
(0.0697)\end{array}$ & $\begin{array}{c}-0.1844 * * * \\
(0.0466)\end{array}$ & $\begin{array}{c}-1.1527^{* *} \\
(0.5019)\end{array}$ & $\begin{array}{l}-0.6711 \\
(0.7574)\end{array}$ & $\begin{array}{l}-0.5469 \\
(0.5536)\end{array}$ & $\begin{array}{c}0.4249 \\
(0.3928)\end{array}$ \\
\hline Program Year 5 & $\begin{array}{c}-0.1553 * * * \\
(0.0585)\end{array}$ & $\begin{array}{l}-0.0839 \\
(0.0707)\end{array}$ & $\begin{array}{l}-0.0247 \\
(0.0787)\end{array}$ & $\begin{array}{c}-0.2055^{* * *} \\
(0.0764)\end{array}$ & $\begin{array}{c}-1.5259 * * * \\
(0.5621)\end{array}$ & $\begin{array}{c}0.4614 \\
(0.7313)\end{array}$ & $\begin{array}{c}-0.2923 \\
(0.6764)\end{array}$ & $\begin{array}{c}0.3320 \\
(0.5208)\end{array}$ \\
\hline Program Year 6 & $\begin{array}{c}-0.2038^{* * *} \\
(0.0760)\end{array}$ & $\begin{array}{c}-0.1525^{*} \\
(0.0821)\end{array}$ & $\begin{array}{l}-0.0463 \\
(0.1057)\end{array}$ & $\begin{array}{c}-0.3009 * * * \\
(0.0910)\end{array}$ & $\begin{array}{c}-1.6557^{* *} \\
(0.7465)\end{array}$ & $\begin{array}{c}0.2994 \\
(0.9787)\end{array}$ & $\begin{array}{c}-0.1431 \\
(0.7844)\end{array}$ & $\begin{array}{c}1.0927^{* *} \\
(0.5062)\end{array}$ \\
\hline Program Year 7 & $\begin{array}{c}-0.1946 * * \\
(0.0966)\end{array}$ & $\begin{array}{l}-0.1013 \\
(0.1292)\end{array}$ & $\begin{array}{c}0.0699 \\
(0.1444)\end{array}$ & $\begin{array}{c}-0.2936 * * * \\
(0.0994)\end{array}$ & $\begin{array}{l}-1.3804 \\
(0.9896)\end{array}$ & $\begin{array}{c}-0.0191 \\
(1.2175)\end{array}$ & $\begin{array}{c}-0.5230 \\
(1.2556)\end{array}$ & $\begin{array}{c}2.1027^{* *} \\
(0.9545)\end{array}$ \\
\hline Program Year 8 & $\begin{array}{c}-0.2347^{* *} \\
(0.1118) \\
\end{array}$ & $\begin{array}{c}-0.2091 \\
(0.1437) \\
\end{array}$ & $\begin{array}{c}0.1050 \\
(0.1479) \\
\end{array}$ & $\begin{array}{c}-0.2991^{* *} \\
(0.1364)\end{array}$ & $\begin{array}{c}-1.5281 \\
(1.1807) \\
\end{array}$ & $\begin{array}{c}-0.0529 \\
(1.2246) \\
\end{array}$ & $\begin{array}{c}-0.6394 \\
(1.5685) \\
\end{array}$ & $\begin{array}{c}3.5507^{* *} \\
(1.3937) \\
\end{array}$ \\
\hline N Obs & 29599 & 3894 & 3379 & 1897 & 29599 & 3894 & 3379 & 1897 \\
\hline $\mathrm{RSq}$ & 0.77 & 0.80 & 0.83 & 0.87 & 0.74 & 0.68 & 0.64 & 0.65 \\
\hline
\end{tabular}

(hespital beds and hospitals per capita), immunization rates (BCG, measles, yellow fever, poliomyelitis and DTP, without the last two and with DT for adults), and public education infrastructure (number of schools and teachers - primary and secondary - per capita). 
Table 8(a): Mortality Effect of PSF by Age Group and Cause of Death, Brazilian Municipalities, 1995-2003

\begin{tabular}{|c|c|c|c|c|c|c|c|c|}
\hline & \multicolumn{8}{|c|}{ Mortality before Age 1} \\
\hline & Perinatal Period & Infectious & External Causes & Endocrine & Respiratory & $\begin{array}{l}\text { Congenital } \\
\text { Anomalies }\end{array}$ & $\begin{array}{c}\text { Nervous System } \\
\text { and Senses } \\
\text { Organs }\end{array}$ & III-Defined \\
\hline Program Year 1 & $\begin{array}{c}0.0879 \\
(0.1590)\end{array}$ & $\begin{array}{c}-0.0784 \\
(0.0589)\end{array}$ & $\begin{array}{c}0.0033 \\
(0.0190)\end{array}$ & $\begin{array}{c}-0.0292 \\
(0.0224)\end{array}$ & $\begin{array}{l}-0.0448 \\
(0.0479)\end{array}$ & $\begin{array}{c}0.0280 \\
(0.0502)\end{array}$ & $\begin{array}{l}-0.0267^{*} \\
(0.0152)\end{array}$ & $\begin{array}{l}-0.1661^{*} \\
(0.1002)\end{array}$ \\
\hline Program Year 2 & $\begin{array}{c}0.1859 \\
(0.1868)\end{array}$ & $\begin{array}{c}-0.1752^{* * *} \\
(0.0638)\end{array}$ & $\begin{array}{l}-0.0123 \\
(0.0210)\end{array}$ & $\begin{array}{l}-0.0292 \\
(0.0275)\end{array}$ & $\begin{array}{l}-0.0470 \\
(0.0512)\end{array}$ & $\begin{array}{c}0.0098 \\
(0.0581)\end{array}$ & $\begin{array}{l}-0.0058 \\
(0.0186)\end{array}$ & $\begin{array}{c}-0.3006 * * * \\
(0.1006)\end{array}$ \\
\hline Program Year 3 & $\begin{array}{l}-0.2225 \\
(0.2520)\end{array}$ & $\begin{array}{c}-0.3464^{* * *} \\
(0.0917)\end{array}$ & $\begin{array}{l}-0.0071 \\
(0.0265)\end{array}$ & $\begin{array}{c}-0.0607^{*} \\
(0.0333)\end{array}$ & $\begin{array}{c}-0.2050 * * * \\
(0.0628)\end{array}$ & $\begin{array}{l}-0.0629 \\
(0.0727)\end{array}$ & $\begin{array}{l}-0.0050 \\
(0.0202)\end{array}$ & $\begin{array}{c}-0.5357 * * * \\
(0.1526)\end{array}$ \\
\hline Program Year 4 & $\begin{array}{c}-0.6870^{*} \\
(0.3818)\end{array}$ & $\begin{array}{c}-0.4511 * * * \\
(0.1222)\end{array}$ & $\begin{array}{c}0.0156 \\
(0.0331)\end{array}$ & $\begin{array}{c}-0.1216 * * * \\
(0.0371)\end{array}$ & $\begin{array}{c}-0.2601^{* * *} \\
(0.0841)\end{array}$ & $\begin{array}{c}-0.1625^{*} \\
(0.0838)\end{array}$ & $\begin{array}{l}-0.0152 \\
(0.0259)\end{array}$ & $\begin{array}{c}-0.5055^{* * *} \\
(0.1798)\end{array}$ \\
\hline Program Year 5 & $\begin{array}{c}-1.2964 * * * \\
(0.4909)\end{array}$ & $\begin{array}{c}-0.4589 * * * \\
(0.1556)\end{array}$ & $\begin{array}{l}-0.0021 \\
(0.0398)\end{array}$ & $\begin{array}{c}-0.1159 * * \\
(0.0468)\end{array}$ & $\begin{array}{c}-0.4238^{* * *} \\
(0.1139)\end{array}$ & $\begin{array}{c}-0.1580 * \\
(0.0899)\end{array}$ & $\begin{array}{c}-0.0074 \\
(0.0293)\end{array}$ & $\begin{array}{c}-0.5556^{* *} \\
(0.2428)\end{array}$ \\
\hline Program Year 6 & $\begin{array}{c}-1.8221^{* * *} \\
(0.6603)\end{array}$ & $\begin{array}{c}-0.6734^{* * *} \\
(0.2000)\end{array}$ & $\begin{array}{l}-0.0127 \\
(0.0412)\end{array}$ & $\begin{array}{c}-0.1757^{* * *} \\
(0.0536)\end{array}$ & $\begin{array}{c}-0.5320 * * * \\
(0.1522)\end{array}$ & $\begin{array}{c}-0.1934 * \\
(0.1066)\end{array}$ & $\begin{array}{l}-0.0539 * \\
(0.0324)\end{array}$ & $\begin{array}{l}-0.5871^{*} \\
(0.3285)\end{array}$ \\
\hline Program Year 7 & $\begin{array}{c}-1.9880^{* *} \\
(0.8464)\end{array}$ & $\begin{array}{c}-0.5590^{* *} \\
(0.2762)\end{array}$ & $\begin{array}{c}-0.0053 \\
(0.0571)\end{array}$ & $\begin{array}{c}-0.1853^{* * *} \\
(0.0718)\end{array}$ & $\begin{array}{c}-0.4504 * * \\
(0.1777)\end{array}$ & $\begin{array}{c}-0.3309^{* *} \\
(0.1578)\end{array}$ & $\begin{array}{l}-0.0573 \\
(0.0406)\end{array}$ & $\begin{array}{c}0.0467 \\
(0.4937)\end{array}$ \\
\hline Program Year 8 & $\begin{array}{c}-3.3990^{* * *} \\
(1.2161)\end{array}$ & $\begin{array}{c}-0.9300 * * * \\
(0.3370) \\
\end{array}$ & $\begin{array}{c}-0.0160 \\
(0.0650) \\
\end{array}$ & $\begin{array}{c}-0.3091^{* * *} \\
(0.0960)\end{array}$ & $\begin{array}{c}-0.7318^{* * *} \\
(0.1996) \\
\end{array}$ & $\begin{array}{c}-0.2039 \\
(0.1889) \\
\end{array}$ & $\begin{array}{c}-0.0674 \\
(0.0545) \\
\end{array}$ & $\begin{array}{c}0.5490 \\
(0.7473) \\
\end{array}$ \\
\hline \multirow[t]{2}{*}{$\mathrm{R} \mathrm{Sq}$} & $\begin{array}{c}42924 \\
0.58\end{array}$ & $\begin{array}{c}42924 \\
0.46\end{array}$ & $\begin{array}{c}42924 \\
0.25\end{array}$ & $\begin{array}{c}42924 \\
0.28\end{array}$ & $\begin{array}{c}42924 \\
0.36\end{array}$ & $\begin{array}{c}42924 \\
0.37\end{array}$ & $\begin{array}{c}42924 \\
0.18\end{array}$ & $\begin{array}{c}42924 \\
0.61\end{array}$ \\
\hline & Neoplasms & Infectious & External Causes & $\begin{array}{c}\text { Mortality betv } \\
\text { Endocrine }\end{array}$ & $\begin{array}{l}\text { Ages } 1 \text { and } 4 \\
\text { Respiratory }\end{array}$ & $\begin{array}{l}\text { Congenital } \\
\text { Anomalies }\end{array}$ & $\begin{array}{c}\text { Nervous System } \\
\text { and Senses } \\
\text { Organs }\end{array}$ & III-Defined \\
\hline Program Year 1 & $\begin{array}{l}-0.0022 \\
(0.0030)\end{array}$ & $\begin{array}{c}0.0001 \\
(0.0063)\end{array}$ & $\begin{array}{l}-0.0088 \\
(0.0059)\end{array}$ & $\begin{array}{c}-0.0021 \\
(0.0031)\end{array}$ & $\begin{array}{c}-0.0178^{* * *} \\
(0.0064)\end{array}$ & $\begin{array}{l}-0.0012 \\
(0.0032)\end{array}$ & $\begin{array}{c}0.0004 \\
(0.0032)\end{array}$ & $\begin{array}{c}0.0035 \\
(0.0069)\end{array}$ \\
\hline Program Year 2 & $\begin{array}{c}0.0021 \\
(0.0035)\end{array}$ & $\begin{array}{c}-0.0089 \\
(0.0062)\end{array}$ & $\begin{array}{l}-0.0067 \\
(0.0065)\end{array}$ & $\begin{array}{l}-0.0055 \\
(0.0036)\end{array}$ & $\begin{array}{c}-0.0165^{* *} \\
(0.0068)\end{array}$ & $\begin{array}{l}-0.0024 \\
(0.0040)\end{array}$ & $\begin{array}{c}0.0029 \\
(0.0034)\end{array}$ & $\begin{array}{l}-0.0082 \\
(0.0077)\end{array}$ \\
\hline Program Year 3 & $\begin{array}{c}0.0005 \\
(0.0036)\end{array}$ & $\begin{array}{c}-0.0213 * * * \\
(0.0076)\end{array}$ & $\begin{array}{c}-0.0059 \\
(0.0075)\end{array}$ & $\begin{array}{l}-0.0048 \\
(0.0043)\end{array}$ & $\begin{array}{c}-0.0146 * \\
(0.0087)\end{array}$ & $\begin{array}{l}-0.0014 \\
(0.0046)\end{array}$ & $\begin{array}{c}0.0017 \\
(0.0043)\end{array}$ & $\begin{array}{l}-0.0132 \\
(0.0104)\end{array}$ \\
\hline Program Year 4 & $\begin{array}{c}-0.0001 \\
(0.0040)\end{array}$ & $\begin{array}{c}-0.0282^{* * *} \\
(0.0088)\end{array}$ & $\begin{array}{c}-0.0212^{* *} \\
(0.0088)\end{array}$ & $\begin{array}{c}-0.0088^{*} \\
(0.0048)\end{array}$ & $\begin{array}{c}-0.0215^{*} \\
(0.0113)\end{array}$ & $\begin{array}{l}-0.0047 \\
(0.0053)\end{array}$ & $\begin{array}{c}-0.0003 \\
(0.0045)\end{array}$ & $\begin{array}{c}-0.0203^{*} \\
(0.0123)\end{array}$ \\
\hline Program Year 5 & $\begin{array}{c}-0.0029 \\
(0.0050)\end{array}$ & $\begin{array}{c}-0.0455^{* * *} \\
(0.0113)\end{array}$ & $\begin{array}{c}-0.0253^{* *} \\
(0.0103)\end{array}$ & $\begin{array}{c}-0.0094 \\
(0.0058)\end{array}$ & $\begin{array}{c}-0.0295^{* *} \\
(0.0142)\end{array}$ & $\begin{array}{l}-0.0032 \\
(0.0056)\end{array}$ & $\begin{array}{l}-0.0080 \\
(0.0053)\end{array}$ & $\begin{array}{l}-0.0242 \\
(0.0161)\end{array}$ \\
\hline Program Year 6 & $\begin{array}{c}0.0009 \\
(0.0055)\end{array}$ & $\begin{array}{c}-0.0402 * * * \\
(0.0126)\end{array}$ & $\begin{array}{c}-0.0375^{* * *} \\
(0.0116)\end{array}$ & $\begin{array}{c}-0.0201 * * * \\
(0.0067)\end{array}$ & $\begin{array}{c}-0.0391 * * \\
(0.0160)\end{array}$ & $\begin{array}{c}-0.0111^{*} \\
(0.0063)\end{array}$ & $\begin{array}{l}-0.0033 \\
(0.0061)\end{array}$ & $\begin{array}{c}-0.0419 * * \\
(0.0198)\end{array}$ \\
\hline Program Year 7 & $\begin{array}{l}-0.0055 \\
(0.0069)\end{array}$ & $\begin{array}{c}-0.0505^{* * *} \\
(0.0161)\end{array}$ & $\begin{array}{c}-0.0304^{* *} \\
(0.0140)\end{array}$ & $\begin{array}{c}-0.0235^{* * *} \\
(0.0080)\end{array}$ & $\begin{array}{c}-0.0550 * * * \\
(0.0186)\end{array}$ & $\begin{array}{l}-0.0083 \\
(0.0082)\end{array}$ & $\begin{array}{c}-0.0124^{*} \\
(0.0070)\end{array}$ & $\begin{array}{l}-0.0168 \\
(0.0256)\end{array}$ \\
\hline Program Year 8 & $\begin{array}{c}-0.0016 \\
(0.0076) \\
\end{array}$ & $\begin{array}{c}-0.0692^{* * *} \\
(0.0188) \\
\end{array}$ & $\begin{array}{c}-0.0396 * * \\
(0.0170) \\
\end{array}$ & $\begin{array}{c}-0.0219^{* *} \\
(0.0094) \\
\end{array}$ & $\begin{array}{c}-0.0684^{* * * *} \\
(0.0225) \\
\end{array}$ & $\begin{array}{r}-0.0117 \\
(0.0103) \\
\end{array}$ & $\begin{array}{c}-0.0143^{*} \\
(0.0087) \\
\end{array}$ & $\begin{array}{l}-0.0126 \\
(0.0312) \\
\end{array}$ \\
\hline N Obs & 48636 & 48636 & 48636 & 48636 & 48636 & 48636 & 48636 & 48636 \\
\hline $\mathrm{RSq}$ & 0.13 & 0.21 & 0.18 & 0.19 & 0.21 & 0.15 & 0.15 & 0.37 \\
\hline
\end{tabular}

per 1,000 in age group. Independent variables: Dummies indicating number of years into the program, municipality fixed-effects and state-specific non-linear trends. All regressions also included as additional controls (not shown in the table): health infrastructure (hospital beds and hospitals per capita), immunization rates (BCG, measles, yellow fever, poliomyelitis and DTP, without the last two and with DT for adults), and public education infrastructure (number of schools and teachers - primary and secondary - per capita). 
Table 8(b): Mortality Effect of PSF by Age Group and Cause of Death, Brazilian Municipalities, 1993-2004

\begin{tabular}{|c|c|c|c|c|c|c|c|}
\hline & \multicolumn{7}{|c|}{ Mortality between Ages 15 and 59} \\
\hline & Neoplasms & External Causes & Endocrine & Respiratory & Circulatory & Digestive & III-Defined \\
\hline \multirow[t]{2}{*}{ Program Year 1} & 0.0042 & -0.0007 & $-0.0124^{* * *}$ & -0.0001 & $-0.0140^{* * *}$ & 0.0006 & -0.0015 \\
\hline & $(0.0031)$ & $(0.0075)$ & $(0.0037)$ & (0.0028) & $(0.0047)$ & $(0.0028)$ & $(0.0056)$ \\
\hline \multirow[t]{2}{*}{ Program Year 2} & 0.0029 & -0.0088 & $-0.0161^{* * *}$ & $-0.0051^{*}$ & $-0.0156 * * *$ & -0.0038 & -0.0095 \\
\hline & (0.0038) & (0.0102) & $(0.0045)$ & (0.0027) & $(0.0057)$ & (0.0031) & (0.0074) \\
\hline \multirow[t]{2}{*}{ Program Year 3} & $0.0078^{*}$ & $-0.0241^{* *}$ & $-0.0224 * * *$ & $-0.0070^{* *}$ & $-0.0216^{* * *}$ & -0.0058 & $-0.0175^{* *}$ \\
\hline & $(0.0045)$ & $(0.0120)$ & $(0.0059)$ & $(0.0033)$ & $(0.0066)$ & $(0.0036)$ & $(0.0086)$ \\
\hline \multirow[t]{2}{*}{ Program Year 4} & 0.0075 & $-0.0383 * * *$ & $-0.0276 * * *$ & $-0.0093 * *$ & $-0.0200 * *$ & $-0.0082^{*}$ & $-0.0316 * * *$ \\
\hline & (0.0054) & $(0.0149)$ & $(0.0072)$ & $(0.0040)$ & $(0.0085)$ & $(0.0043)$ & $(0.0111)$ \\
\hline \multirow[t]{2}{*}{ Program Year 5} & 0.0073 & $-0.0474 * *$ & $-0.0352^{* * *}$ & $-0.0089^{*}$ & $-0.0196^{*}$ & $-0.0092^{*}$ & $-0.0314 * *$ \\
\hline & $(0.0065)$ & $(0.0210)$ & $(0.0089)$ & $(0.0051)$ & $(0.0100)$ & $(0.0056)$ & $(0.0145)$ \\
\hline \multirow[t]{2}{*}{ Program Year 6} & 0.0048 & $-0.0637^{* *}$ & $-0.0437^{* * *}$ & $-0.0139 * *$ & $-0.0275^{* *}$ & $-0.0111^{*}$ & $-0.0413^{* *}$ \\
\hline & (0.0081) & $(0.0271)$ & $(0.0103)$ & $(0.0066)$ & (0.0132) & $(0.0064)$ & $(0.0207)$ \\
\hline \multirow[t]{2}{*}{ Program Year 7} & $0.0216^{*}$ & $-0.0669 * *$ & $-0.0511^{* * *}$ & $-0.0137^{*}$ & -0.0196 & $-0.0237^{* *}$ & $-0.0493 * *$ \\
\hline & $(0.0122)$ & $(0.0335)$ & $(0.0128)$ & $(0.0077)$ & (0.0203) & $(0.0093)$ & (0.0244) \\
\hline \multirow[t]{2}{*}{ Program Year 8} & 0.0049 & $-0.1129 * * *$ & $-0.0492^{* * *}$ & $-0.0312^{* * *}$ & -0.0059 & $-0.0254 * *$ & -0.0311 \\
\hline & $(0.0141)$ & $(0.0402)$ & $(0.0135)$ & $(0.0100)$ & $(0.0233)$ & $(0.0121)$ & $(0.0311)$ \\
\hline N Obs & 42931 & 42931 & 42931 & 42931 & 42931 & 42931 & 42931 \\
\hline \multirow{3}{*}{$\mathrm{R} \mathrm{Sq}$} & 0.67 & 0.77 & 0.58 & 0.54 & 0.70 & 0.48 & 0.68 \\
\hline & \multicolumn{7}{|c|}{ Mortality above Age 59} \\
\hline & Neoplasms & External Causes & Endocrine & Respiratory & Circulatory & III-Defined & \\
\hline \multirow[t]{2}{*}{ Program Year 1} & -0.0013 & 0.0095 & -0.0102 & 0.0476 & -0.0776 & 0.0952 & \\
\hline & $(0.0337)$ & $(0.0150)$ & (0.0249) & $(0.0465)$ & $(0.0837)$ & $(0.0854)$ & \\
\hline \multirow{2}{*}{ Program Year 2} & $0.0756^{*}$ & -0.0130 & 0.0186 & 0.0311 & -0.0925 & -0.0876 & \\
\hline & $(0.0446)$ & $(0.0178)$ & (0.0318) & $(0.0511)$ & (0.1019) & (0.1088) & \\
\hline \multirow[t]{2}{*}{ Program Year 3} & $0.0820^{*}$ & -0.0024 & -0.0088 & -0.0271 & -0.1237 & $-0.2815^{*}$ & \\
\hline & $(0.0465)$ & $(0.0184)$ & (0.0400) & (0.0549) & (0.1335) & $(0.1441)$ & \\
\hline \multirow[t]{2}{*}{ Program Year 4} & 0.0878 & -0.0128 & -0.0494 & 0.0166 & -0.2309 & $-0.4816 * *$ & \\
\hline & $(0.0575)$ & $(0.0214)$ & (0.0511) & (0.0647) & (0.1781) & $(0.1906)$ & \\
\hline \multirow[t]{2}{*}{ Program Year 5} & 0.0659 & -0.0188 & -0.0801 & -0.0397 & -0.2766 & $-0.3693^{*}$ & \\
\hline & $(0.0698)$ & $(0.0278)$ & $(0.0582)$ & $(0.0838)$ & (0.2014) & $(0.2234)$ & \\
\hline \multirow[t]{2}{*}{ Program Year 6} & $0.1590^{*}$ & -0.0381 & -0.0417 & 0.0493 & -0.3051 & $-0.5848 *$ & \\
\hline & $(0.0910)$ & (0.0299) & $(0.0720)$ & (0.1132) & $(0.2987)$ & $(0.2991)$ & \\
\hline \multirow[t]{2}{*}{ Program Year 7} & 0.1077 & -0.0193 & -0.0438 & 0.0124 & -0.4783 & -0.4993 & \\
\hline & $(0.1223)$ & (0.0404) & (0.0893) & (0.1514) & (0.4795) & $(0.3977)$ & \\
\hline \multirow[t]{2}{*}{ Program Year 8} & 0.1550 & -0.0581 & -0.1799 & -0.0929 & -0.7436 & -0.1479 & \\
\hline & $(0.1643)$ & $(0.0464)$ & $(0.1105)$ & $(0.1800)$ & $(0.6622)$ & $(0.5698)$ & \\
\hline N Obs & 42931 & 42931 & 42931 & 42931 & 42931 & 42931 & \\
\hline $\mathrm{R} \mathrm{Sq}$ & 0.82 & 0.35 & 0.64 & 0.76 & 0.82 & 0.79 & \\
\hline
\end{tabular}




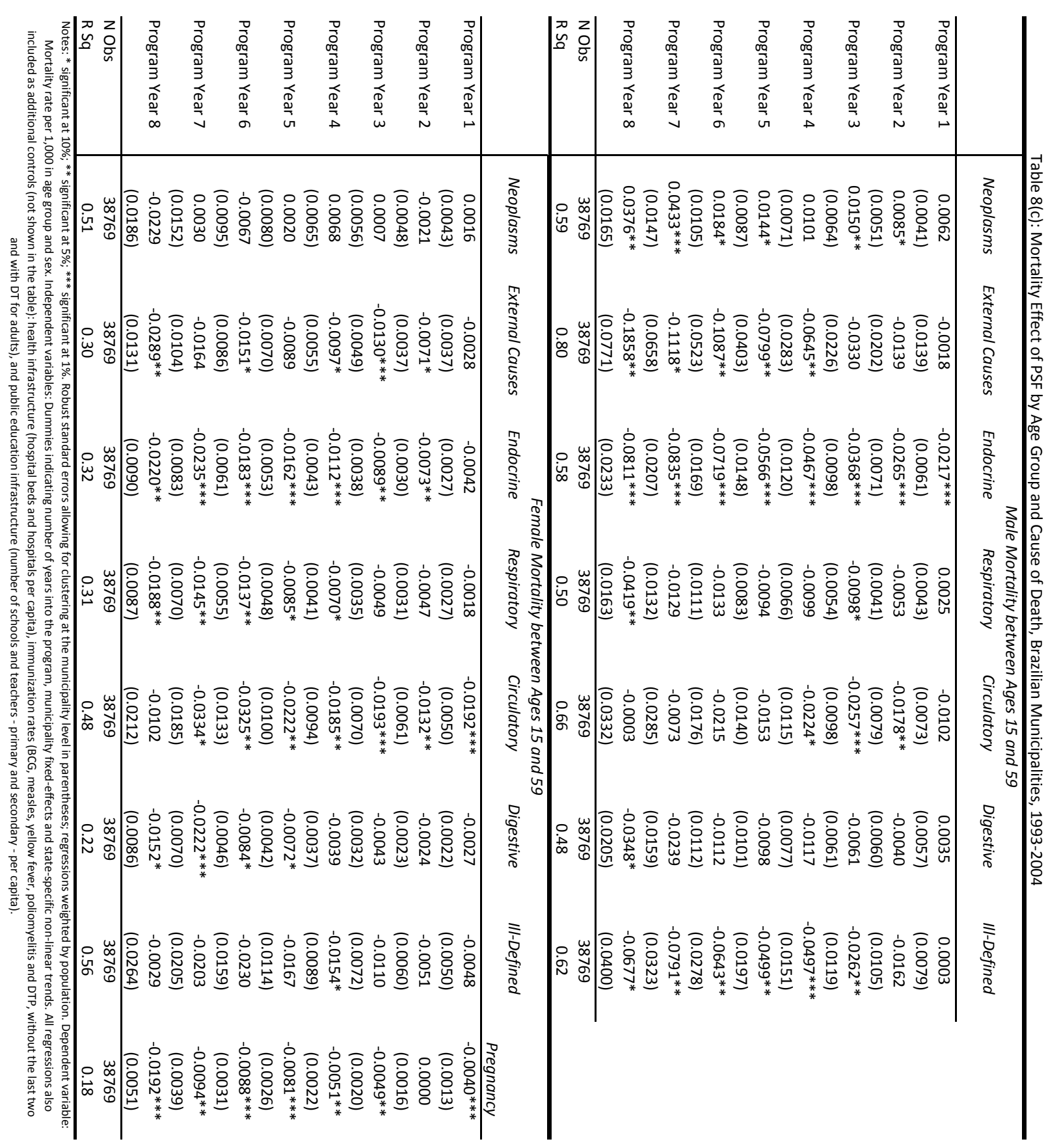




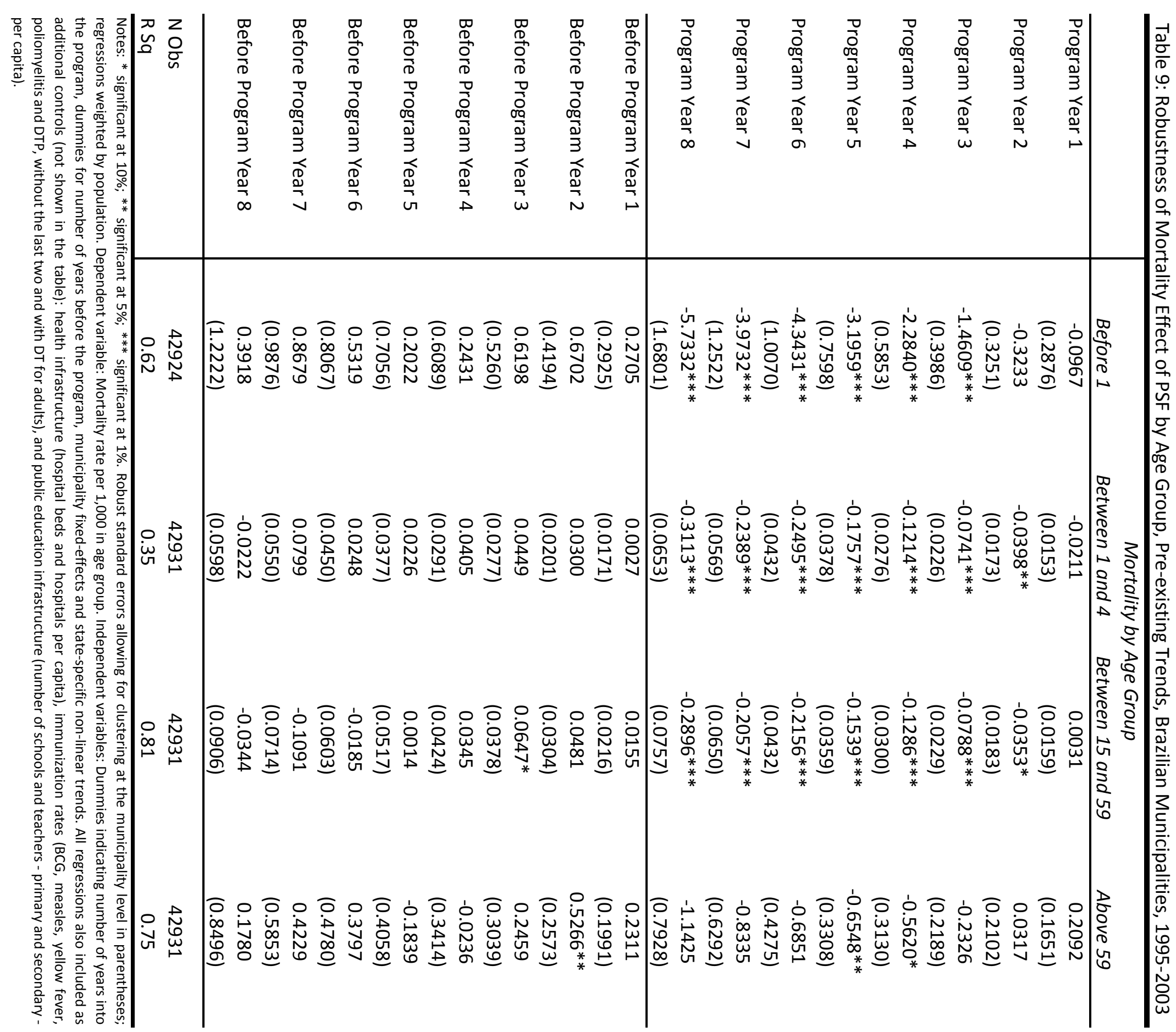




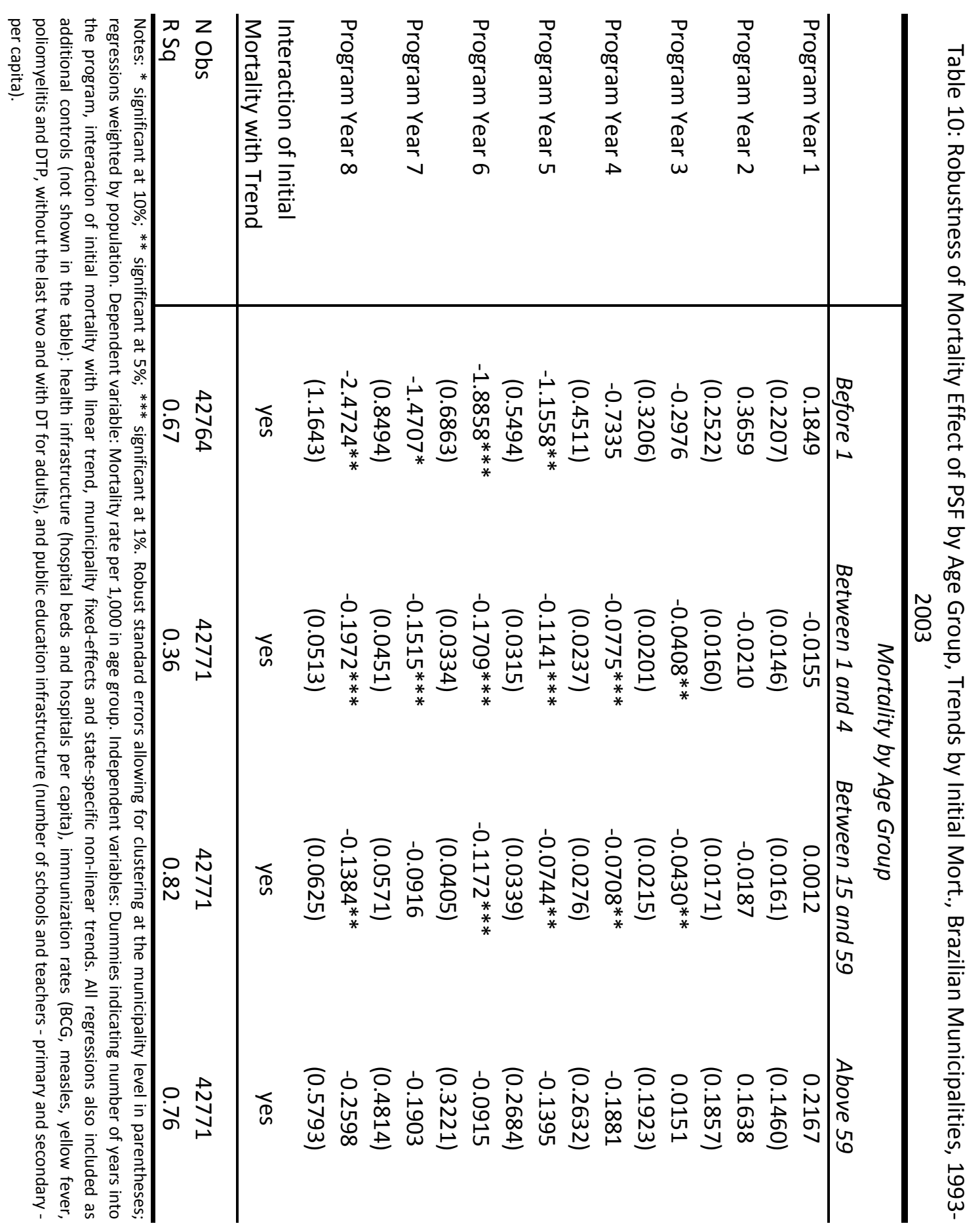


Table 11: Descriptive Statistics, Individual Level Data, Brazilian North and Northeast Regions, 1993-2004

\begin{tabular}{|c|c|c|c|c|c|c|c|}
\hline \multirow[b]{2}{*}{ Year } & \multicolumn{2}{|c|}{ Number of Municipalities in the Sample } & \multicolumn{2}{|c|}{ Children (between 10 and 17) } & \multicolumn{3}{|c|}{ Adults (between 18 and 55) } \\
\hline & with PSF & without PSF & child labor (\%) & school enrollment (\%) & labor supply (\%) & employment (\%) & $\begin{array}{c}\text { fertility - birth last } \\
21 \text { months (\% of } \\
\text { women) }\end{array}$ \\
\hline 1993 & 0 & 316 & 31.69 & 77.65 & 73.64 & 70.55 & 18.79 \\
\hline 1995 & 0 & 316 & 31.26 & 79.56 & 73.95 & 71.14 & 17.33 \\
\hline 1996 & 28 & 288 & 25.65 & 81.17 & 71.87 & 68.86 & 16.68 \\
\hline 1997 & 46 & 270 & 26.77 & 83.97 & 73.41 & 70.01 & 15.22 \\
\hline 1998 & 109 & 207 & 27.33 & 86.77 & 73.93 & 70.35 & 15.06 \\
\hline 1999 & 166 & 150 & 26.94 & 89.09 & 75.69 & 71.36 & 8.44 \\
\hline 2001 & 243 & 73 & 22.51 & 90.21 & 74.34 & 69.51 & 13.87 \\
\hline 2002 & 264 & 52 & 23.12 & 91.07 & 75.20 & 70.61 & 12.83 \\
\hline 2003 & 273 & 43 & 21.92 & 90.99 & 76.29 & 71.14 & 12.18 \\
\hline 2004 & 291 & 25 & 20.43 & 90.67 & 77.04 & 72.14 & 11.76 \\
\hline
\end{tabular}

Note: Data for children between 10 and 17 or adults between 18 and 55; 316 municipalities in the North and Northeast regions; calculcated from 10 rounds of the PNAD (1993-2004, excluding 2000). Child labor and adult employment is defined as work during the last week. School enrollment indicates whether the child is enrolled in regular school. Fertility indicates whether the woman experienced a birth over the last 21 months. 


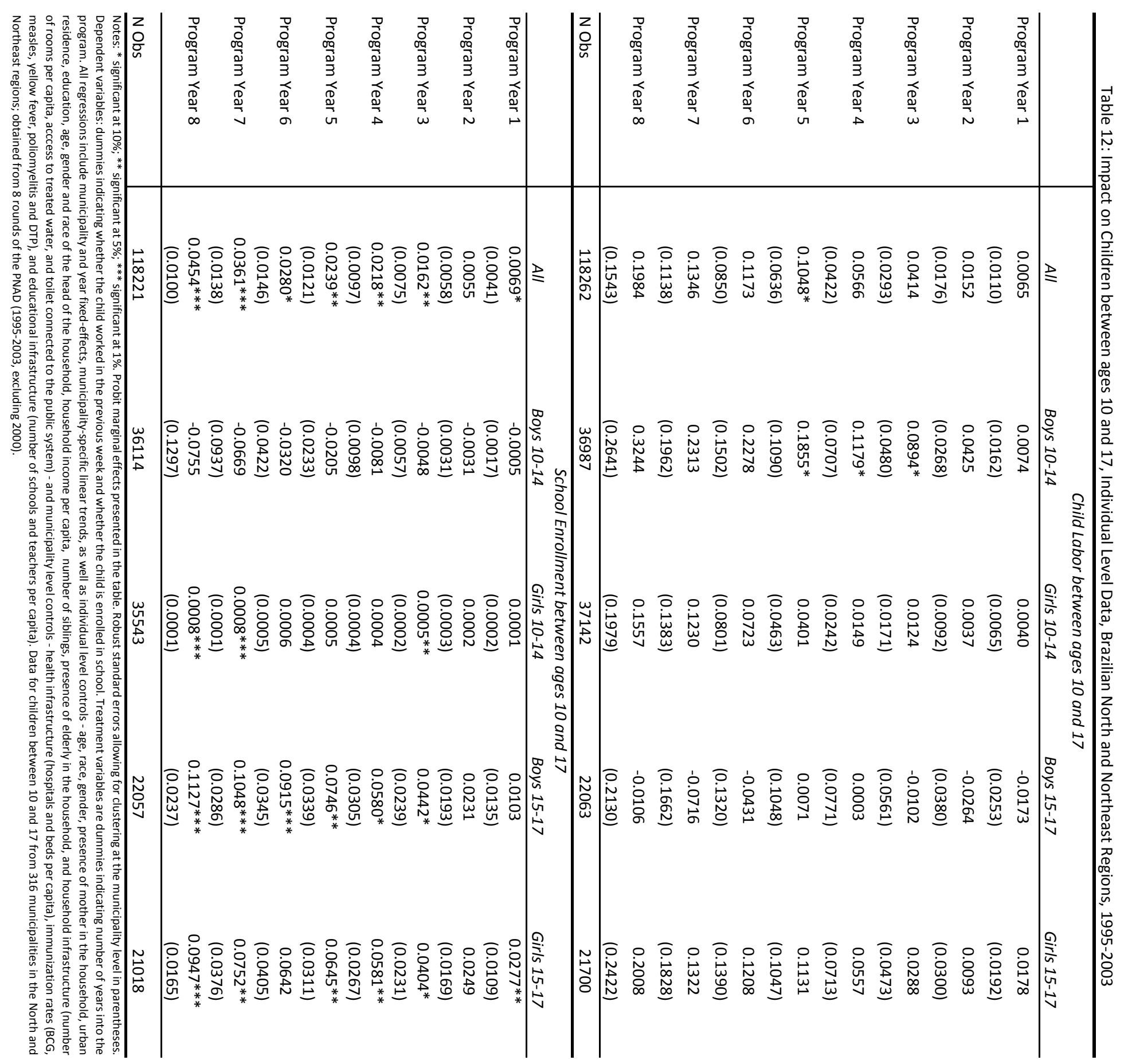


Table 13: Impact on Adult Labor, Individual Level Data, Brazilian North and Northeast Regions, 1995-2003

\begin{tabular}{|c|c|c|c|c|c|c|c|c|c|c|c|c|}
\hline & \multicolumn{12}{|c|}{ Labor Supply of Adults between 18 and 55} \\
\hline & All & Men & Women & $18-30$ & Men $18-30$ & Women $18-30$ & $31-40$ & Men $31-40$ & Women $31-40$ & $41-50$ & Men 41-50 & Women 41-50 \\
\hline \multirow[t]{2}{*}{ Program Year 1} & $0.0103^{*}$ & 0.0040 & 0.0110 & -0.0007 & -0.0002 & -0.0004 & 0.0124 & 0.0004 & 0.0162 & $0.0150^{*}$ & 0.0062 & 0.0153 \\
\hline & $(0.0056)$ & $(0.0026)$ & $(0.0100)$ & $(0.0102)$ & $(0.0002)$ & $(0.0167)$ & $(0.0086)$ & $(0.0004)$ & $(0.0150)$ & $(0.0080)$ & $(0.0039)$ & $(0.0150)$ \\
\hline \multirow[t]{2}{*}{ Program Year 2} & $0.0170^{*}$ & 0.0057 & 0.0207 & 0.0143 & -0.0004 & 0.0370 & $0.0224^{*}$ & 0.0005 & 0.0246 & 0.0099 & 0.0081 & 0.0033 \\
\hline & $(0.0087)$ & $(0.0039)$ & $(0.0150)$ & $(0.0148)$ & $(0.0004)$ & $(0.0243)$ & $(0.0127)$ & $(0.0005)$ & $(0.0212)$ & $(0.0128)$ & (0.0059) & $(0.0225)$ \\
\hline \multirow[t]{2}{*}{ Program Year 3} & $0.0248 * *$ & 0.0066 & 0.0331 & 0.0133 & -0.0009 & 0.0473 & $0.0376^{* *}$ & 0.0003 & 0.0458 & 0.0180 & 0.0103 & 0.0112 \\
\hline & $(0.0122)$ & $(0.0056)$ & $(0.0222)$ & $(0.0215)$ & $(0.0010)$ & $(0.0355)$ & $(0.0176)$ & $(0.0009)$ & $(0.0302)$ & $(0.0189)$ & $(0.0090)$ & $(0.0345)$ \\
\hline \multirow[t]{2}{*}{ Program Year 4} & $0.0317^{*}$ & 0.0070 & 0.0434 & 0.0032 & -0.0027 & 0.0589 & $0.0554^{* *}$ & 0.0006 & 0.0636 & 0.0174 & 0.0085 & 0.0091 \\
\hline & $(0.0164)$ & $(0.0080)$ & $(0.0291)$ & $(0.0297)$ & $(0.0030)$ & $(0.0488)$ & $(0.0227)$ & $(0.0011)$ & (0.0399) & $(0.0266)$ & $(0.0135)$ & $(0.0465)$ \\
\hline \multirow[t]{2}{*}{ Program Year 5} & $0.0518^{* *}$ & 0.0109 & $0.0759 * *$ & 0.0153 & -0.0052 & 0.0874 & $0.0670^{* *}$ & 0.0001 & 0.0841 & 0.0475 & 0.0152 & 0.0539 \\
\hline & $(0.0211)$ & $(0.0095)$ & $(0.0386)$ & (0.0399) & $(0.0074)$ & $(0.0656)$ & $(0.0284)$ & (0.0019) & $(0.0522)$ & $(0.0345)$ & $(0.0152)$ & $(0.0628)$ \\
\hline \multirow[t]{2}{*}{ Program Year 6} & $0.0568 * *$ & 0.0092 & $0.0844^{*}$ & 0.0062 & -0.0168 & 0.0994 & $0.0810^{* *}$ & -0.0003 & 0.0944 & 0.0437 & 0.0139 & 0.0543 \\
\hline & $(0.0272)$ & $(0.0133)$ & $(0.0494)$ & $(0.0524)$ & $(0.0261)$ & $(0.0853)$ & $(0.0351)$ & $(0.0031)$ & $(0.0673)$ & $(0.0452)$ & $(0.0208)$ & $(0.0808)$ \\
\hline \multirow[t]{2}{*}{ Program Year 7} & $0.0746 * *$ & 0.0140 & $0.1052^{*}$ & 0.0200 & -0.0269 & 0.1150 & $0.0939 * *$ & 0.0001 & 0.1084 & 0.0658 & 0.0160 & 0.0854 \\
\hline & $(0.0327)$ & $(0.0136)$ & $(0.0616)$ & $(0.0669)$ & $(0.0527)$ & $(0.1096)$ & $(0.0402)$ & $(0.0033)$ & $(0.0822)$ & $(0.0547)$ & $(0.0241)$ & $(0.1017)$ \\
\hline \multirow[t]{2}{*}{ Program Year 8} & $0.0680^{*}$ & 0.0040 & 0.1092 & -0.0072 & -0.1159 & 0.1227 & $0.0976^{* *}$ & -0.0044 & 0.1154 & 0.0486 & 0.0043 & 0.0728 \\
\hline & $(0.0412)$ & $(0.0246)$ & $(0.0758)$ & $(0.0878)$ & $(0.2038)$ & $(0.1370)$ & $(0.0480)$ & $(0.0138)$ & $(0.1000)$ & $(0.0707)$ & $(0.0431)$ & $(0.1270)$ \\
\hline \multirow[t]{3}{*}{ N Obs } & 279943 & 127331 & 152511 & 80328 & 28768 & 48105 & 101005 & 44972 & 53772 & 98610 & 47616 & 50634 \\
\hline & \multicolumn{12}{|c|}{ Employment of Adults between 18 and 55} \\
\hline & All & Men & Women & $18-30$ & Men 18-30 & Women $18-30$ & $31-40$ & Men $31-40$ & Women 31-40 & $41-50$ & Men 41-50 & Women 41-50 \\
\hline \multirow[t]{2}{*}{ Program Year 1} & 0.0090 & $0.0087^{*}$ & 0.0042 & -0.0039 & 0.0023 & -0.0138 & 0.0125 & 0.0017 & 0.0134 & 0.0139 & 0.0101 & 0.0102 \\
\hline & $(0.0066)$ & $(0.0045)$ & $(0.0104)$ & (0.0108) & $(0.0028)$ & $(0.0163)$ & $(0.0097)$ & $(0.0025)$ & (0.0159) & $(0.0088)$ & $(0.0066)$ & $(0.0153)$ \\
\hline \multirow[t]{2}{*}{ Program Year 2} & 0.0168 & $0.0134^{*}$ & 0.0136 & 0.0163 & 0.0036 & 0.0260 & 0.0177 & 0.0009 & 0.0141 & 0.0140 & $0.0172^{*}$ & 0.0036 \\
\hline & $(0.0107)$ & $(0.0071)$ & $(0.0163)$ & $(0.0159)$ & $(0.0043)$ & $(0.0255)$ & $(0.0149)$ & $(0.0039)$ & $(0.0232)$ & $(0.0143)$ & $(0.0099)$ & $(0.0231)$ \\
\hline \multirow[t]{2}{*}{ Program Year 3} & $0.0332 * *$ & $0.0217^{* *}$ & 0.0341 & 0.0237 & 0.0045 & 0.0454 & $0.0387^{* *}$ & 0.0011 & 0.0433 & $0.0334^{*}$ & $0.0298^{* *}$ & 0.0193 \\
\hline & $(0.0129)$ & $(0.0086)$ & $(0.0220)$ & $(0.0220)$ & $(0.0061)$ & $(0.0375)$ & (0.0191) & $(0.0057)$ & $(0.0301)$ & (0.0199) & $(0.0130)$ & $(0.0344)$ \\
\hline \multirow[t]{2}{*}{ Program Year 4} & $0.0399 * *$ & $0.0258 * *$ & 0.0410 & 0.0165 & 0.0005 & 0.0589 & $0.0553^{* *}$ & 0.0037 & 0.0544 & 0.0336 & $0.0306^{*}$ & 0.0144 \\
\hline & $(0.0175)$ & $(0.0119)$ & $(0.0292)$ & $(0.0306)$ & $(0.0108)$ & $(0.0524)$ & $(0.0253)$ & $(0.0074)$ & $(0.0408)$ & $(0.0278)$ & $(0.0181)$ & $(0.0469)$ \\
\hline \multirow[t]{2}{*}{ Program Year 5} & $0.0668^{* * *}$ & $0.0367^{* * *}$ & $0.0770^{* *}$ & 0.0447 & 0.0060 & 0.0904 & $0.0681^{* *}$ & 0.0002 & 0.0799 & $0.0700 * *$ & $0.0444 * *$ & 0.0622 \\
\hline & $(0.0224)$ & $(0.0129)$ & $(0.0390)$ & $(0.0408)$ & $(0.0116)$ & $(0.0714)$ & $(0.0325)$ & $(0.0118)$ & $(0.0535)$ & $(0.0356)$ & $(0.0184)$ & $(0.0640)$ \\
\hline \multirow[t]{2}{*}{ Program Year 6} & $0.0802^{* * *}$ & $0.0436 * * *$ & $0.0889^{*}$ & 0.0610 & 0.0049 & 0.1280 & $0.0870^{* *}$ & 0.0046 & 0.0830 & 0.0693 & $0.0465^{* *}$ & 0.0619 \\
\hline & $(0.0285)$ & $(0.0147)$ & $(0.0505)$ & $(0.0514)$ & $(0.0160)$ & $(0.0930)$ & $(0.0406)$ & $(0.0123)$ & $(0.0706)$ & $(0.0462)$ & $(0.0232)$ & $(0.0821)$ \\
\hline \multirow[t]{2}{*}{ Program Year 7} & $0.1093^{* * *}$ & $0.0530 * * *$ & $0.1211^{*}$ & $0.1092^{*}$ & 0.0126 & 0.1732 & $0.1066^{* *}$ & 0.0067 & 0.1096 & $0.0959^{*}$ & $0.0521 * *$ & 0.0947 \\
\hline & $(0.0333)$ & $(0.0123)$ & $(0.0631)$ & $(0.0623)$ & $(0.0103)$ & (0.1189) & $(0.0466)$ & $(0.0135)$ & $(0.0855)$ & $(0.0552)$ & $(0.0230)$ & $(0.1042)$ \\
\hline Program Year 8 & $\begin{array}{c}0.1136^{* * *} \\
(0.0410)\end{array}$ & $\begin{array}{c}0.0501^{* * *} \\
(0.0168)\end{array}$ & $\begin{array}{l}0.1424^{*} \\
(0.0765)\end{array}$ & $\begin{array}{c}0.0944 \\
(0.0791)\end{array}$ & $\begin{array}{c}0.0029 \\
(0.0287)\end{array}$ & $\begin{array}{c}0.2068 \\
(0.1444)\end{array}$ & $\begin{array}{c}0.1139 * * \\
(0.0559)\end{array}$ & $\begin{array}{c}0.0017 \\
(0.0226)\end{array}$ & $\begin{array}{c}0.1159 \\
(0.1059)\end{array}$ & $\begin{array}{c}0.1004 \\
(0.0673)\end{array}$ & $\begin{array}{c}0.0495 \\
(0.0302)\end{array}$ & $\begin{array}{c}0.1131 \\
(0.1266)\end{array}$ \\
\hline N Obs & 279943 & 127385 & 152511 & 80328 & 30917 & 48105 & 101005 & 46456 & 53772 & 98610 & 47813 & 50634 \\
\hline
\end{tabular}

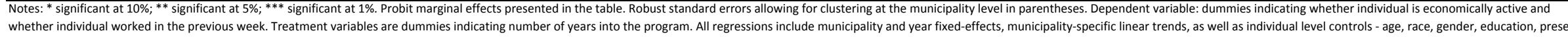
of spouse in the household, urban residence, metropolitan region, presence of elderly and children in the household, and household infrastructure (number of rooms per capita, acccess to treated water, and toilet connected to the public system) - and municipality level controls - health

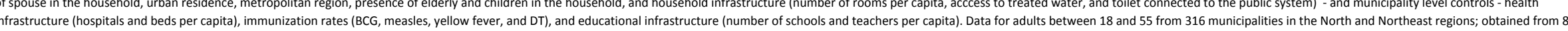
rounds of the PNAD (1995-2003, excluding 2000). 
Table 14: Impact on Fertility (Birth over the Last 21 Months), Individual Level Data, Brazilian North and

Northeast Regions, 1995-2003

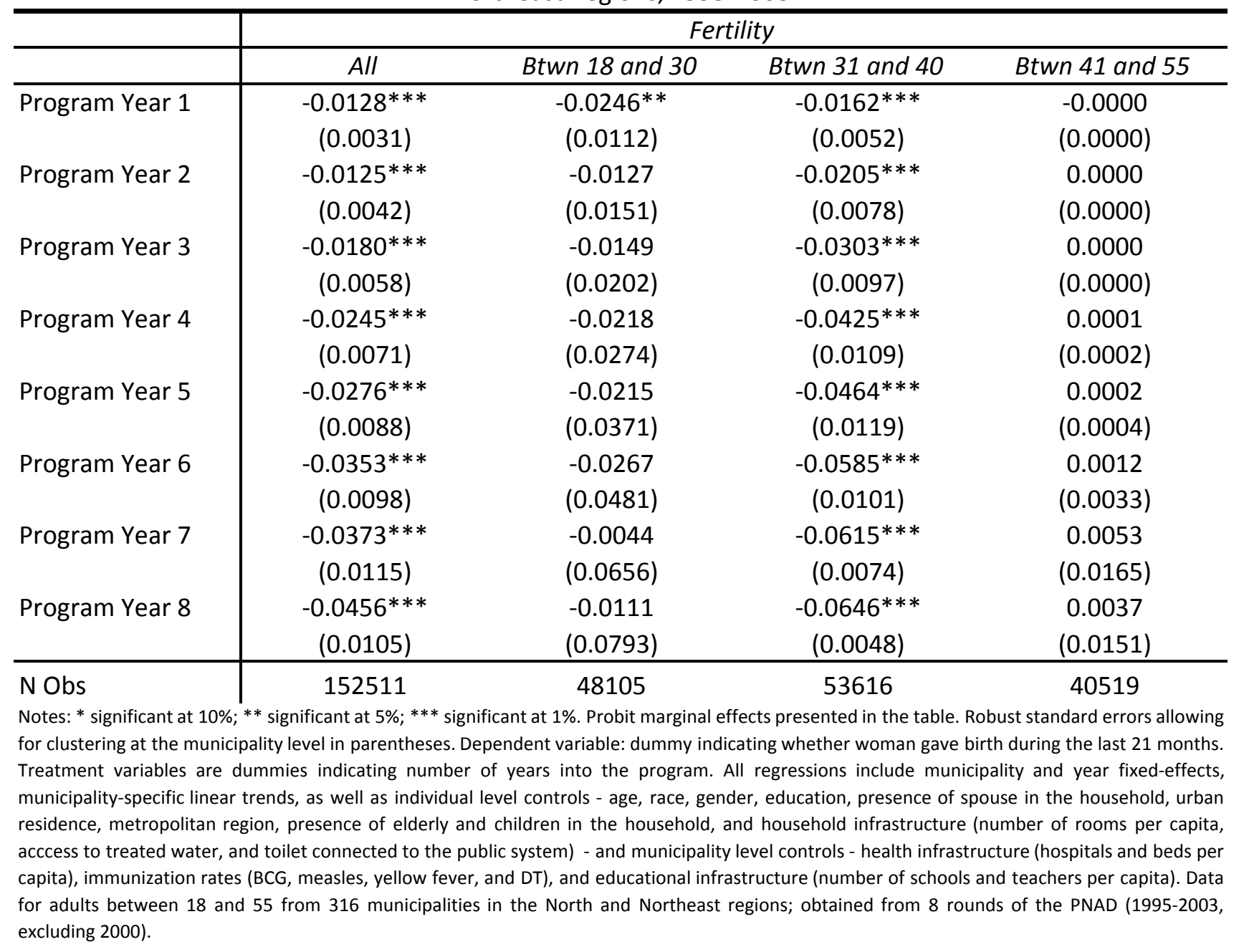


Table 15: Impact on Children between ages 10 and 17 by Household Caharacteristics, Individual Level Data, Brazilian North and Northeast Regions, $1995-2003$

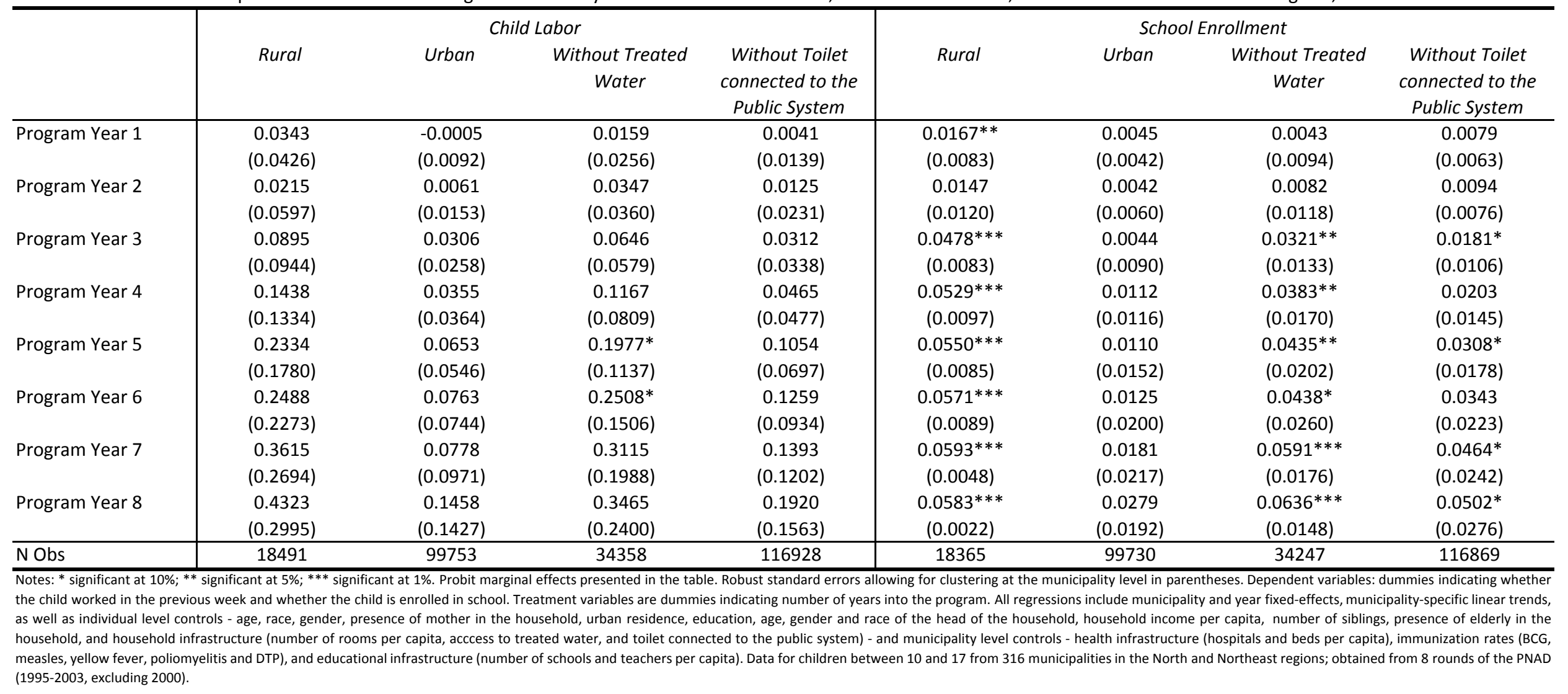


Table 16: Impact on Adult Labor between ages 18 and 55 by Household Caharacteristics, Individual Level Data, Brazilian North and Northeast Regions, 1995-2003

\begin{tabular}{|c|c|c|c|c|c|c|c|c|}
\hline & \multicolumn{4}{|c|}{ Adult Labor Supply } & \multicolumn{4}{|c|}{ Adult Employment } \\
\hline & Rural & Urban & $\begin{array}{c}\text { Without Treated } \\
\text { Water }\end{array}$ & $\begin{array}{c}\text { Without Toilet } \\
\text { connected to the } \\
\text { Public System }\end{array}$ & Rural & Urban & $\begin{array}{c}\text { Without Treated } \\
\text { Water }\end{array}$ & $\begin{array}{c}\text { Without Toilet } \\
\text { connected to the } \\
\text { Public System }\end{array}$ \\
\hline Program Year 1 & $\begin{array}{c}0.0127 \\
(0.0140)\end{array}$ & $\begin{array}{l}0.0108^{*} \\
(0.0057)\end{array}$ & $\begin{array}{c}0.0007 \\
(0.0101)\end{array}$ & $\begin{array}{c}0.0130 * * \\
(0.0066)\end{array}$ & $\begin{array}{c}0.0122 \\
(0.0150)\end{array}$ & $\begin{array}{c}0.0099 \\
(0.0069)\end{array}$ & $\begin{array}{l}-0.0023 \\
(0.0110)\end{array}$ & $\begin{array}{c}0.0099 \\
(0.0074)\end{array}$ \\
\hline Program Year 2 & $\begin{array}{c}0.0199 \\
(0.0222)\end{array}$ & $\begin{array}{l}0.0168 * \\
(0.0091)\end{array}$ & $\begin{array}{c}0.0105 \\
(0.0151)\end{array}$ & $\begin{array}{c}0.0215 * * \\
(0.0102)\end{array}$ & $\begin{array}{c}0.0169 \\
(0.0239)\end{array}$ & $\begin{array}{c}0.0180 \\
(0.0111)\end{array}$ & $\begin{array}{c}0.0123 \\
(0.0166)\end{array}$ & $\begin{array}{c}0.0151 \\
(0.0111)\end{array}$ \\
\hline Program Year 3 & $\begin{array}{c}0.0487 \\
(0.0324)\end{array}$ & $\begin{array}{l}0.0205^{*} \\
(0.0125)\end{array}$ & $\begin{array}{c}0.0194 \\
(0.0221)\end{array}$ & $\begin{array}{l}0.0270 * \\
(0.0143)\end{array}$ & $\begin{array}{c}0.0499 \\
(0.0339)\end{array}$ & $\begin{array}{c}0.0314^{* *} \\
(0.0132)\end{array}$ & $\begin{array}{c}0.0296 \\
(0.0234)\end{array}$ & $\begin{array}{c}0.0327 * * \\
(0.0147)\end{array}$ \\
\hline Program Year 4 & $\begin{array}{c}0.0592 \\
(0.0433)\end{array}$ & $\begin{array}{c}0.0258 \\
(0.0166)\end{array}$ & $\begin{array}{c}0.0242 \\
(0.0301)\end{array}$ & $\begin{array}{c}0.0378 * * \\
(0.0189)\end{array}$ & $\begin{array}{c}0.0569 \\
(0.0456)\end{array}$ & $\begin{array}{c}0.0377^{* *} \\
(0.0179)\end{array}$ & $\begin{array}{c}0.0301 \\
(0.0320)\end{array}$ & $\begin{array}{c}0.0415^{* *} \\
(0.0200)\end{array}$ \\
\hline Program Year 5 & $\begin{array}{c}0.0815 \\
(0.0541)\end{array}$ & $\begin{array}{c}0.0461 * * \\
(0.0215)\end{array}$ & $\begin{array}{c}0.0420 \\
(0.0396)\end{array}$ & $\begin{array}{c}0.0608 * * \\
(0.0244)\end{array}$ & $\begin{array}{c}0.0754 \\
(0.0574)\end{array}$ & $\begin{array}{c}0.0663 * * * \\
(0.0229)\end{array}$ & $\begin{array}{c}0.0587 \\
(0.0413)\end{array}$ & $\begin{array}{c}0.0683 * * * \\
(0.0257)\end{array}$ \\
\hline Program Year 6 & $\begin{array}{l}0.1168 * \\
(0.0618)\end{array}$ & $\begin{array}{l}0.0473^{*} \\
(0.0279)\end{array}$ & $\begin{array}{c}0.0410 \\
(0.0517)\end{array}$ & $\begin{array}{c}0.0686 * * \\
(0.0310)\end{array}$ & $\begin{array}{l}0.1159 * \\
(0.0658)\end{array}$ & $\begin{array}{c}0.0773 * * * \\
(0.0293)\end{array}$ & $\begin{array}{c}0.0651 \\
(0.0531)\end{array}$ & $\begin{array}{c}0.0830 * * \\
(0.0325)\end{array}$ \\
\hline Program Year 7 & $\begin{array}{c}0.1494^{* *} \\
(0.0635)\end{array}$ & $\begin{array}{c}0.0630 * \\
(0.0341)\end{array}$ & $\begin{array}{c}0.0470 \\
(0.0658)\end{array}$ & $\begin{array}{c}0.0887^{* *} \\
(0.0368)\end{array}$ & $\begin{array}{c}0.1535^{* *} \\
(0.0680)\end{array}$ & $\begin{array}{c}0.1055^{* * *} \\
(0.0344)\end{array}$ & $\begin{array}{c}0.0817 \\
(0.0655)\end{array}$ & $\begin{array}{c}0.1119 * * * \\
(0.0379)\end{array}$ \\
\hline Program Year 8 & $\begin{array}{c}0.1840 * * * \\
(0.0583)\end{array}$ & $\begin{array}{c}0.0532 \\
(0.0435)\end{array}$ & $\begin{array}{c}0.0329 \\
(0.0858)\end{array}$ & $\begin{array}{c}0.0804 * \\
(0.0468)\end{array}$ & $\begin{array}{c}0.1859 * * * \\
(0.0663)\end{array}$ & $\begin{array}{c}0.1091^{* *} \\
(0.0428)\end{array}$ & $\begin{array}{c}0.0829 \\
(0.0814)\end{array}$ & $\begin{array}{c}0.1198 * * * \\
(0.0459)\end{array}$ \\
\hline $\mathrm{NObs}$ & 32555 & 247384 & 71770 & 190351 & 32555 & 247384 & 71769 & 190351 \\
\hline
\end{tabular}

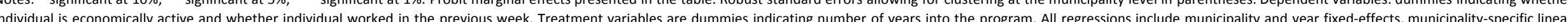

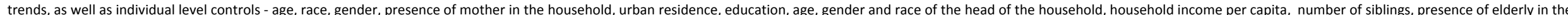

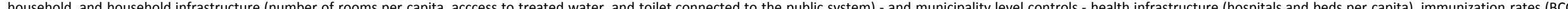

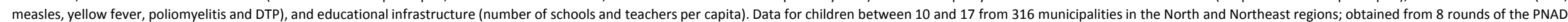
(1995-2003, excluding 2000). 
Table 17: Impact on Fertility (Birth over last 21 Months) between ages 18 and 55 by Household Caharacteristics, Individual Level Data, Brazilian North and Northeast Regions, 1995-2003

\begin{tabular}{|c|c|c|c|c|}
\hline & \multicolumn{4}{|c|}{ Fertility } \\
\hline & Rural & Urban & $\begin{array}{c}\text { Without Treated } \\
\text { Water }\end{array}$ & $\begin{array}{l}\text { Without Toilet } \\
\text { connected to the } \\
\text { Public System }\end{array}$ \\
\hline \multirow[t]{2}{*}{ Program Year 1} & $-0.0175^{* *}$ & $-0.0119 * * *$ & $-0.0134^{*}$ & $-0.0157^{* * *}$ \\
\hline & (0.0085) & (0.0033) & (0.0078) & (0.0043) \\
\hline \multirow[t]{2}{*}{ Program Year 2} & 0.0079 & $-0.0149 * * *$ & -0.0131 & $-0.0144 * *$ \\
\hline & $(0.0156)$ & $(0.0046)$ & $(0.0112)$ & (0.0059) \\
\hline \multirow[t]{2}{*}{ Program Year 3} & 0.0136 & $-0.0211^{* * *}$ & -0.0197 & $-0.0256 * * *$ \\
\hline & $(0.0237)$ & $(0.0061)$ & $(0.0150)$ & $(0.0077)$ \\
\hline \multirow[t]{2}{*}{ Program Year 4} & 0.0254 & $-0.0280 * * *$ & -0.0221 & $-0.0300 * * *$ \\
\hline & $(0.0348)$ & $(0.0074)$ & $(0.0204)$ & $(0.0098)$ \\
\hline \multirow[t]{2}{*}{ Program Year 5} & 0.0244 & $-0.0312 * * *$ & -0.0283 & $-0.0328 * * *$ \\
\hline & $(0.0458)$ & $(0.0090)$ & $(0.0251)$ & $(0.0126)$ \\
\hline \multirow[t]{2}{*}{ Program Year 6} & 0.0246 & $-0.0391 * * *$ & -0.0438 & $-0.0430 * * *$ \\
\hline & $(0.0612)$ & (0.0096) & $(0.0267)$ & $(0.0146)$ \\
\hline \multirow[t]{2}{*}{ Program Year 7} & 0.0647 & $-0.0422 * * *$ & -0.0262 & $-0.0437^{* *}$ \\
\hline & $(0.1064)$ & (0.0101) & $(0.0427)$ & $(0.0180)$ \\
\hline \multirow[t]{2}{*}{ Program Year 8} & 0.0386 & $-0.0482 * * *$ & $-0.0618^{* *}$ & $-0.0590 * * *$ \\
\hline & $(0.1180)$ & $(0.0089)$ & $(0.0267)$ & $(0.0161)$ \\
\hline $\mathrm{NObs}$ & 17158 & 135314 & 38199 & 132883 \\
\hline \multicolumn{5}{|c|}{$\begin{array}{l}\text { Notes: }{ }^{*} \text { significant at } 10 \% ;{ }^{* *} \text { significant at } 5 \% ;{ }^{* *} \text { significant at } 1 \% \text {. Probit marginal effects presented in the table. Robust standard errors allowing for } \\
\text { clustering at the municipality level in parentheses. Dependent variables: dummy indicating whether woman experienced a birth over the last } 21 \text { months. } \\
\text { Treatment variables are dummies indicating number of years into the program. All regressions include municipality and year fixed-effects, municipality-specific } \\
\text { linear trends, as well as individual level controls - age, race, gender, presence of mother in the household, urban residence, education, age, gender and race of } \\
\text { the head of the household, household income per capita, number of siblings, presence of elderly in the household, and household infrastructure (number of } \\
\text { rooms per capita, acccess to treated water, and toilet connected to the public system) - and municipality level controls - health infrastructure (hospitals and } \\
\text { beds per capita), immunization rates (BCG, measles, yellow fever, poliomyelitis and DTP), and educational infrastructure (number of schools and teachers per } \\
\text { capita). Data for children between } 10 \text { and } 17 \text { from } 316 \text { municipalities in the North and Northeast regions; obtained from } 8 \text { rounds of the PNAD (1995-2003, } \\
\text { excluding 2000). }\end{array}$} \\
\hline
\end{tabular}


Table A.1: Data

\begin{tabular}{|c|c|c|}
\hline Variable & Source & Coverage \\
\hline \multicolumn{3}{|l|}{ Mortality: } \\
\hline by age, gender, and cause of death & DATASUS/Brazilian Ministry of Health & 1993-2004 \\
\hline \multicolumn{3}{|l|}{ Education Infrastructure: } \\
\hline number of teachers in public schools & School Census/INPE & 1993-2003 \\
\hline number of public schools & School Census/INPE & 1993-2003 \\
\hline \multicolumn{3}{|l|}{ Immunization: } \\
\hline BCG, measles, yellow fever, poliomyelitis, DTP, DT & DATASUS/Brazilian Ministry of Health & 1995-2004 \\
\hline \multicolumn{3}{|l|}{ Health Infrastructure: } \\
\hline number of hospitals & DATASUS/Brazilian Ministry of Health & 1993-2003 \\
\hline number of hospital beds & DATASUS/Brazilian Ministry of Health & 1993-2003 \\
\hline \multicolumn{3}{|l|}{ Individual Data: } \\
\hline individual and household variables & Brazilian Household Survey (PNAD-IBGE) & 1993-2004 \\
\hline GDP per capita & IBGE & 1999-2004 \\
\hline
\end{tabular}




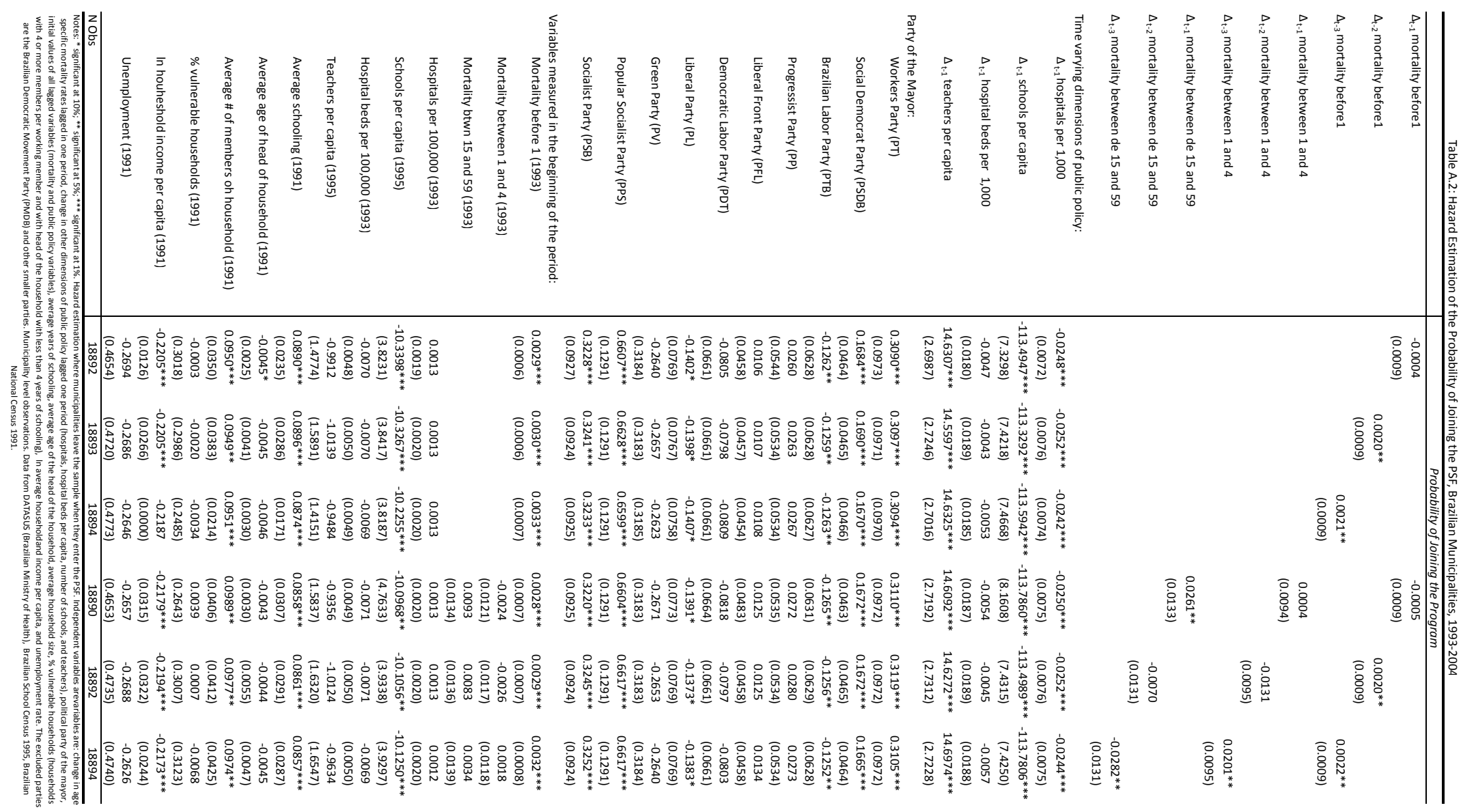




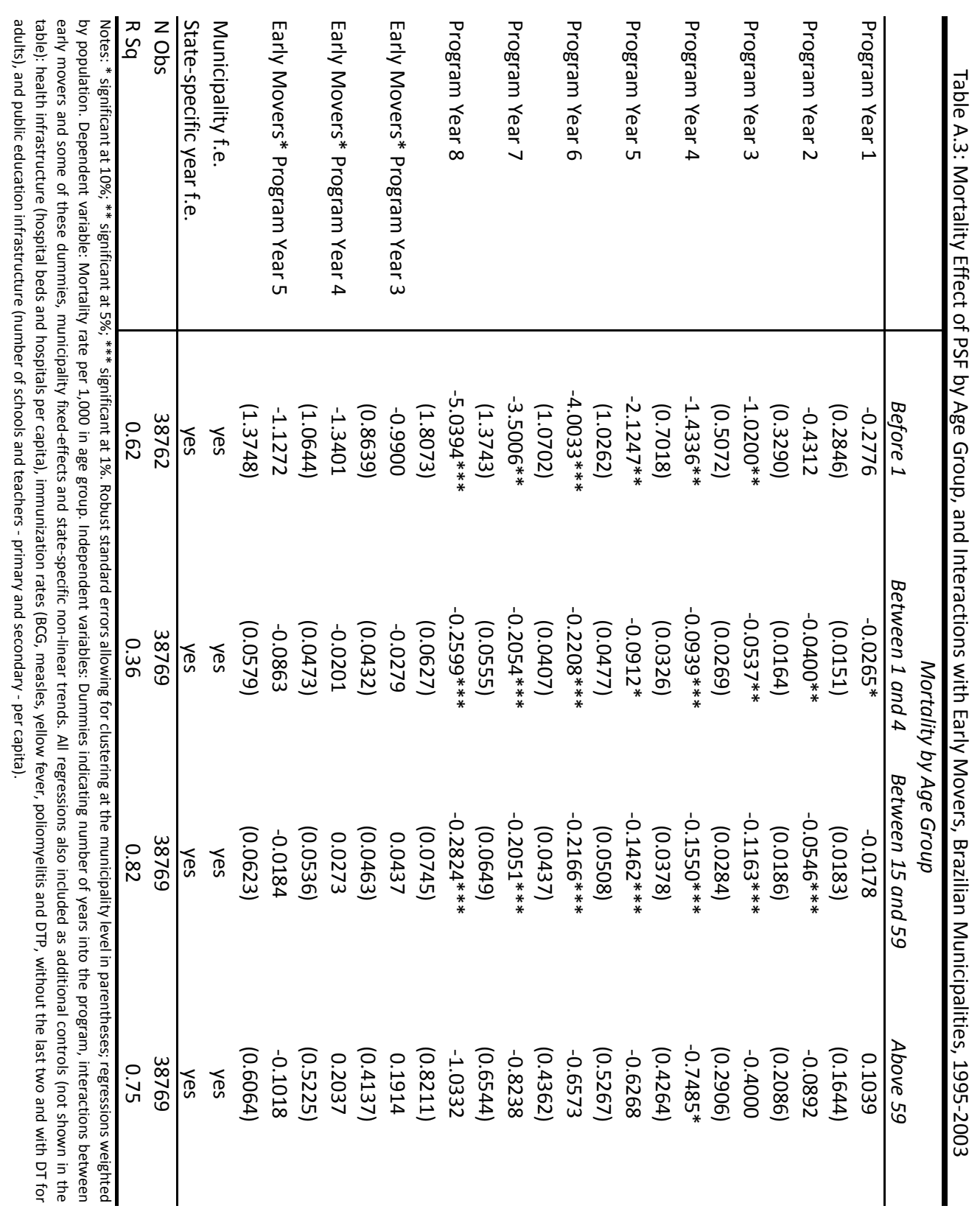




\begin{tabular}{|c|c|c|c|c|c|c|c|c|c|c|}
\hline $\begin{array}{c}\text { Infectious and parasitic } \\
\text { diseases }\end{array}$ & Neoplasms & $\begin{array}{c}\text { Endocrine, } \\
\text { nutritional and } \\
\text { metabolic diseases }\end{array}$ & $\begin{array}{c}\text { Nervous system } \\
\text { diseases }\end{array}$ & $\begin{array}{l}\text { Circulatory } \\
\text { diseases }\end{array}$ & $\begin{array}{l}\text { Respiratory } \\
\text { diseases }\end{array}$ & $\begin{array}{c}\text { Digestive } \\
\text { diseases }\end{array}$ & $\begin{array}{l}\text { Affections in the } \\
\text { perinatal period }\end{array}$ & $\begin{array}{l}\text { Congenite malformation, } \\
\text { deformities and } \\
\text { chromosomal anomalies }\end{array}$ & $\begin{array}{c}\text { Symptoms, signs and } \\
\text { abnormality finds ill- } \\
\text { defined }\end{array}$ & $\begin{array}{c}\text { External causes } \\
\text { of mortality and } \\
\text { morbidity }\end{array}$ \\
\hline Infectious intestinal diseases & $\begin{array}{l}\text { Neoplasms of lip, oral cavity } \\
\text { and pharynx }\end{array}$ & Diabetes mellitus & Meningitis & $\begin{array}{l}\text { Acute rheumatic fever } \\
\text { and rheumatic heart } \\
\text { disiseases }\end{array}$ & Influenza (grippe) & $\begin{array}{l}\text { Duodenal, peptic and } \\
\text { gastric ulcer }\end{array}$ & $\begin{array}{l}\text { Foetus and newly born babies } \\
\text { affected by complication in the } \\
\text { pregnancy or in the childbirth }\end{array}$ & $\begin{array}{l}\text { Congenite malformation of } \\
\text { nervous system }\end{array}$ & Senility & Transport accidents \\
\hline Cholera & Esophageal neoplasms & $\begin{array}{l}\text { Malnutrition, } \\
\text { underfeeding }\end{array}$ & Alzheimer's disease & Hypertensive diseases & Pneumonia & Peritonitis & $\begin{array}{l}\text { Trouble related with duration } \\
\text { of pregnancy and fetal growth }\end{array}$ & $\begin{array}{l}\text { Circulatory congenite } \\
\text { malformation }\end{array}$ & Death without medical care & Falls \\
\hline $\begin{array}{l}\text { Diarrhea and gastrits of } \\
\text { infectious origin. }\end{array}$ & Stomach neoplasms & $\begin{array}{l}\text { Other endocrine, } \\
\text { nutritional and metabolic } \\
\text { diseases }\end{array}$ & epilepsy & |schaemic heart disease & $\begin{array}{l}\text { Other acute lower } \\
\text { airways infections }\end{array}$ & Liver diseases & Childbirth traumatism & $\begin{array}{l}\begin{array}{l}\text { Other congenite malformation, } \\
\text { deformitites and chromosomal } \\
\text { anomalies }\end{array} \\
\end{array}$ & $\begin{array}{l}\text { other Symptoms, signs and } \\
\text { abnormality finds ill-defined }\end{array}$ & $\begin{array}{l}\text { Drowning accidental } \\
\text { submersion }\end{array}$ \\
\hline $\begin{array}{l}\text { Other Infectious intestinal } \\
\text { diseases }\end{array}$ & $\begin{array}{l}\text { Neoplasms of the Colon, } \\
\text { Rectum, and Anus }\end{array}$ & & $\begin{array}{l}\text { Other nervous } \\
\text { system diseases }\end{array}$ & \begin{tabular}{|l}
$\begin{array}{l}\text { Acute myocardial } \\
\text { infarction }\end{array}$ \\
\end{tabular} & Bronchiolitis & $\begin{array}{l}\text { Alcoholic liver } \\
\text { diseases }\end{array}$ & $\begin{array}{l}\text { Respiratory and cardiovascular } \\
\text { troubles in the perinatal period }\end{array}$ & & & $\begin{array}{l}\text { Smoke and fire } \\
\text { exposition }\end{array}$ \\
\hline Typhoid. & Liver neoplasms & & & Other heart diseases & $\begin{array}{l}\text { Chronic diseases in the } \\
\text { lower airways }\end{array}$ & $\begin{array}{l}\text { Liver fibrosis and liver } \\
\text { cirrhosis }\end{array}$ & $\begin{array}{l}\text { Other affections in the } \\
\text { perinatal period }\end{array}$ & & & Poisoning \\
\hline Tuberculosis & Pancreatic neoplasms & & & Cerebrovascular diseases & Asthma & Other liver diseases & & & & Suicide \\
\hline Pulmonary tuberculosis & Laryngeal neoplasms & & & Atheroschlerosis & \begin{tabular}{|l} 
other respiratory \\
diseases
\end{tabular} & Cholecystitis & & & & Aggression \\
\hline Other tuberculosis & $\begin{array}{l}\text { Neoplasms of the trachea, } \\
\text { bronchi, and lung }\end{array}$ & & & $\begin{array}{l}\text { Other circulatory } \\
\text { diseases }\end{array}$ & & \begin{tabular}{|l} 
Other digestive \\
diseases
\end{tabular} & & & & $\begin{array}{l}\text { Events and facts } \\
\text { without intention } \\
\text { defined } \\
\end{array}$ \\
\hline Other bacterium diseases & Skin neoplasms & & & & & & & & & \begin{tabular}{|l} 
War operations and \\
|egal interventions
\end{tabular} \\
\hline Pestilential disease & Mammary neoplasms & & & & & & & & & $\begin{array}{l}\begin{array}{l}\text { other external } \\
\text { causes }\end{array} \\
\end{array}$ \\
\hline Leptospirosis & Cervical neoplasms & & & & & & & & & \\
\hline Leprosy & Uterine neoplasms & & & & & & & & & \\
\hline $\begin{array}{l}\text { Tetanus } \\
\end{array}$ & Ovarian neoplasms & & & & & & & & & \\
\hline Neonatal Tetanus & Prostate neoplasm & & & & & & & & & \\
\hline Obstetric Tetanus & Vesical neoplasms & & & & & & & & & \\
\hline Accidental Tetanus & $\begin{array}{l}\text { Meningeal, encephalon and } \\
\text { other nervous system } \\
\text { neoplasms }\end{array}$ & & & & & & & & & \\
\hline Diphtheria & Lymphoma not-Hodgkin & & & & & & & & & \\
\hline Whooping cough & $\begin{array}{l}\text { Multiple myelome and plasma } \\
\text { cell nooplasms }\end{array}$ & & & & & & & & & \\
\hline Infectious meningitis & \begin{tabular}{|l|l|} 
\\
\end{tabular} & & & & & & & & & \\
\hline Septicaemia & Benign neoplasm & & & & & & & & & \\
\hline Sexual diseases & Other neoplasms & & & & & & & & & \\
\hline \multirow{2}{*}{\multicolumn{11}{|c|}{$\begin{array}{l}\text { Viral diseases } \\
\text { Acute poliomyelitis }\end{array}$}} \\
\hline & & & & & & & & & & \\
\hline \multicolumn{11}{|l|}{$\begin{array}{l}\text { Rabies } \\
\end{array}$} \\
\hline \multicolumn{11}{|l|}{ Dengue (breakbone fever) } \\
\hline \multirow{2}{*}{\multicolumn{11}{|c|}{$\begin{array}{l}\text { Yellow fever } \\
\text { Other viral fevers }\end{array}$}} \\
\hline & & & & & & & & & & \\
\hline \multicolumn{11}{|l|}{ Measles } \\
\hline \multirow{2}{*}{\multicolumn{11}{|c|}{$\begin{array}{l}\text { Viral hepatitis } \\
\text { HIV diseases }\end{array}$}} \\
\hline & & & & & & & & & & \\
\hline \multicolumn{11}{|l|}{$\begin{array}{l}\text { Protozoa diseases } \\
\end{array}$} \\
\hline \multicolumn{11}{|l|}{ Malaria } \\
\hline \multirow{2}{*}{\multicolumn{11}{|c|}{$\begin{array}{l}\text { Leishmaniosis } \\
\text { Chagas' disease }\end{array}$}} \\
\hline & & & & & & & & & & \\
\hline \multicolumn{11}{|l|}{ Toxoplasmosis } \\
\hline \multicolumn{11}{|l|}{ Helminthiasis } \\
\hline \multicolumn{11}{|l|}{ Schistosomiasis } \\
\hline \multirow{2}{*}{\multicolumn{11}{|c|}{$\begin{array}{l}\text { Cysticercosils } \\
\text { Other helminthiasis }\end{array}$}} \\
\hline & & & & & & & & & & \\
\hline $\begin{array}{l}\text { Other infectious and parasitic } \\
\text { diseases }\end{array}$ & & & & & & & & & & \\
\hline
\end{tabular}


Figure1: Municipality Coverage of the Family Health Program Brazil, 1993-2006

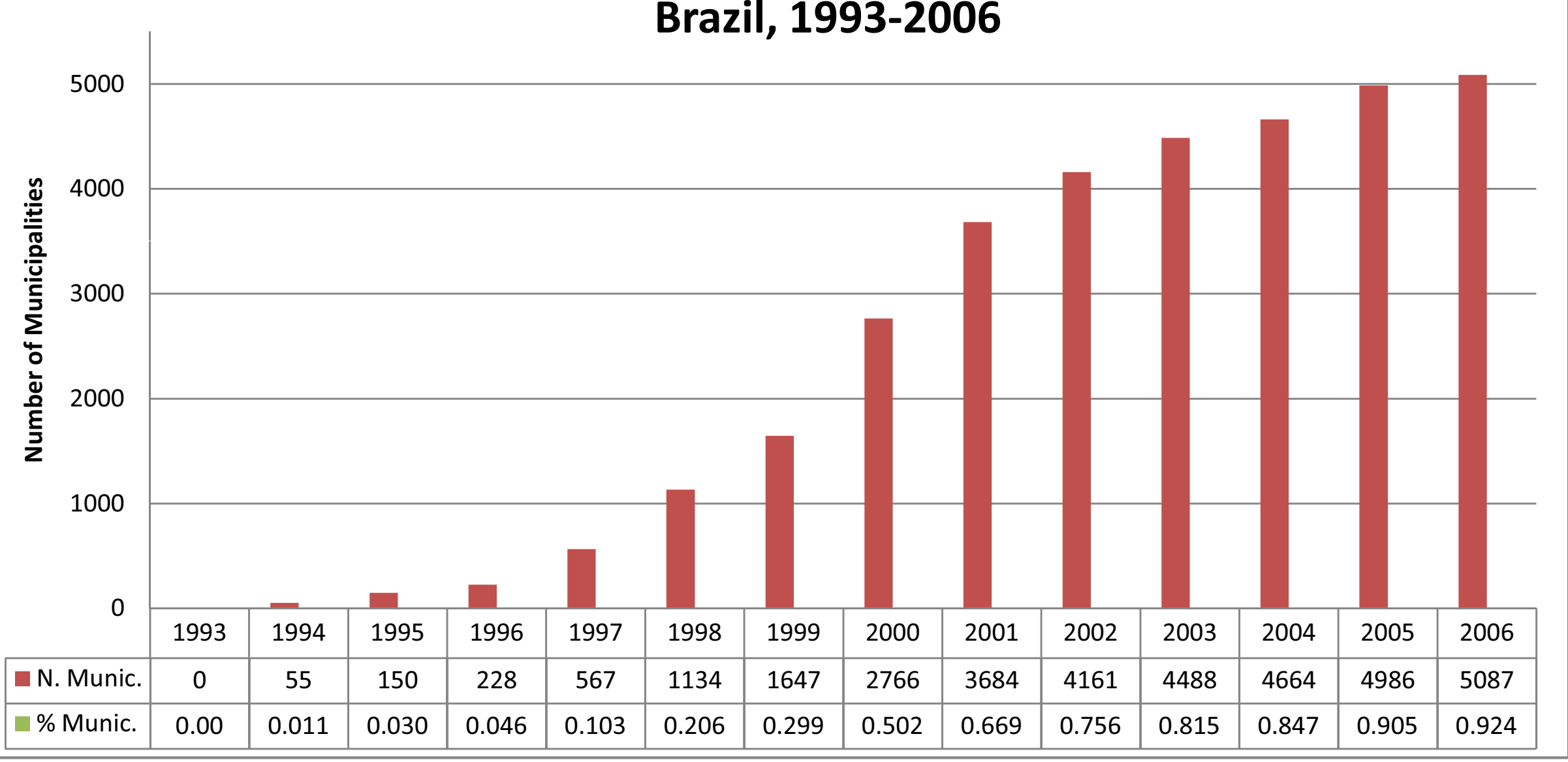




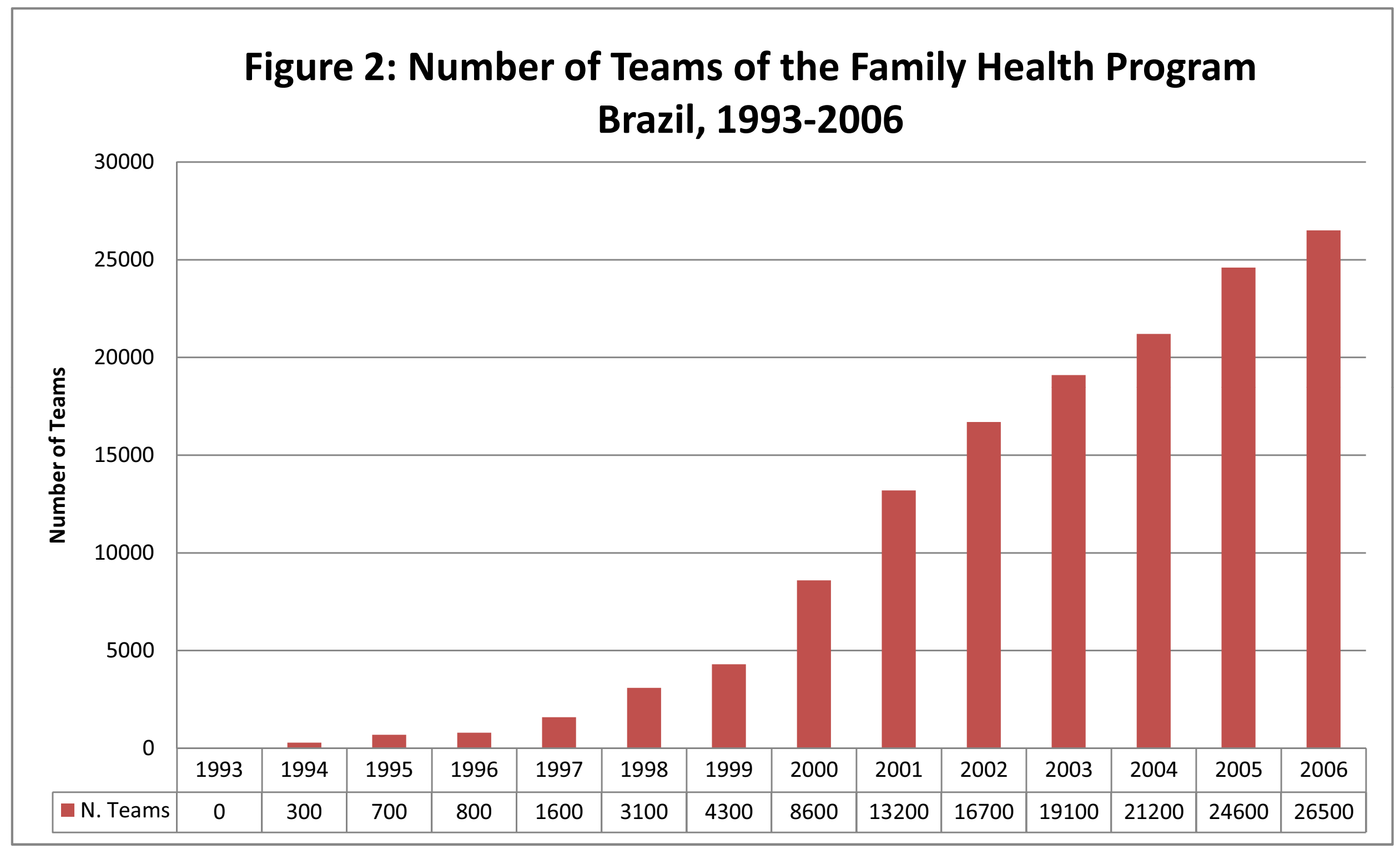


Figure 3: Geographic Expansion of the Family Health Program, Brazil, 1998, 2000, 2005
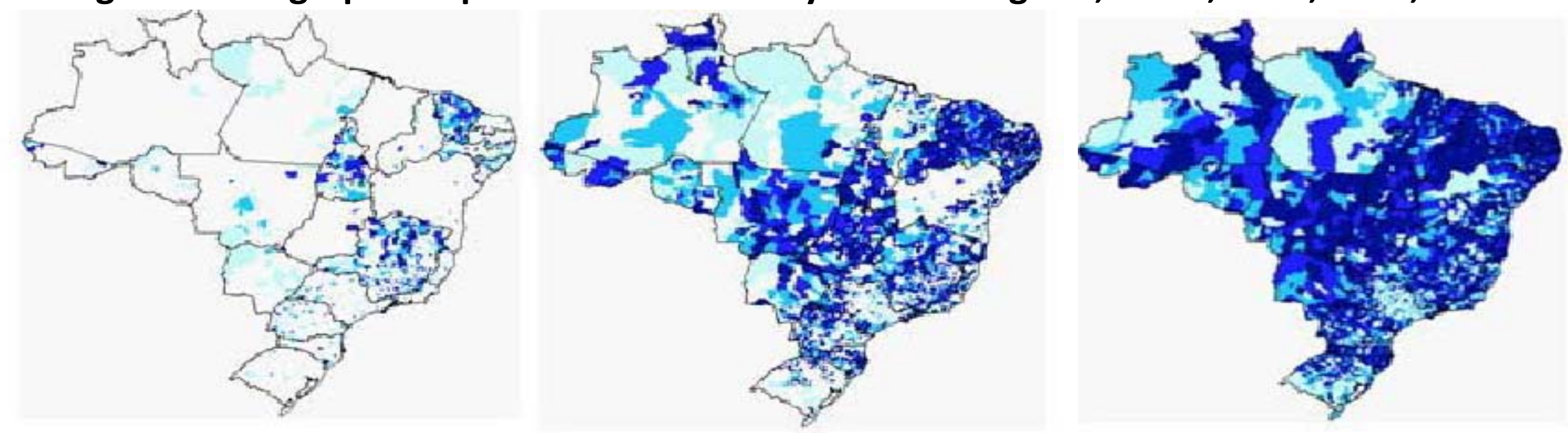

Source: Brazilian Ministry of Health (2006) 
Figure 4: Time Profile of the Impact of the Family Health Program - Coefficients from Table 1

(a) Effect of PSF on Mortality before 1 (and 5\% C.I.)

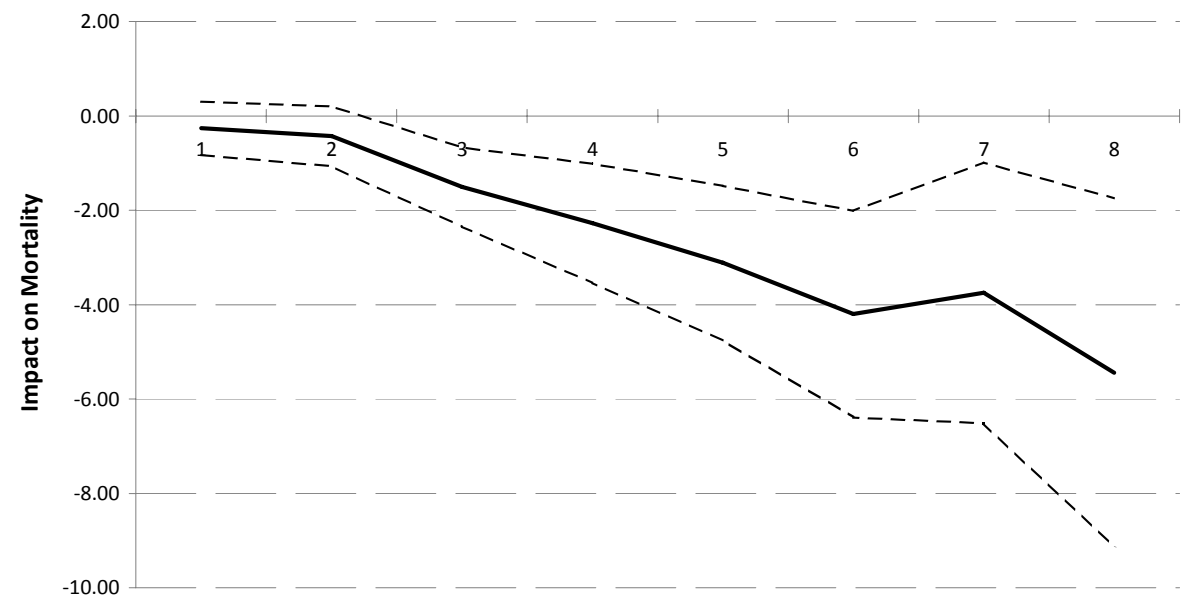

Year of Implementation

(c) Effect of PSF on Mortality btwn 15 and 59 (and 5\%

C.I.)

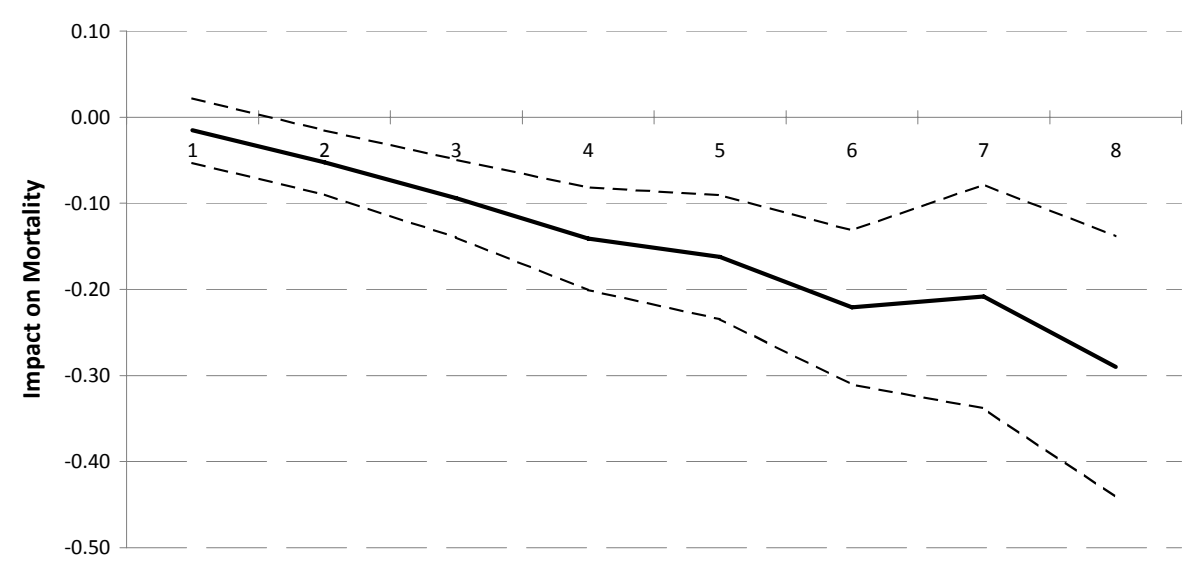

Year of Implementation (b) Effect of PSF on Mortality btwn 1 and 4 (and 5\% C.I.)

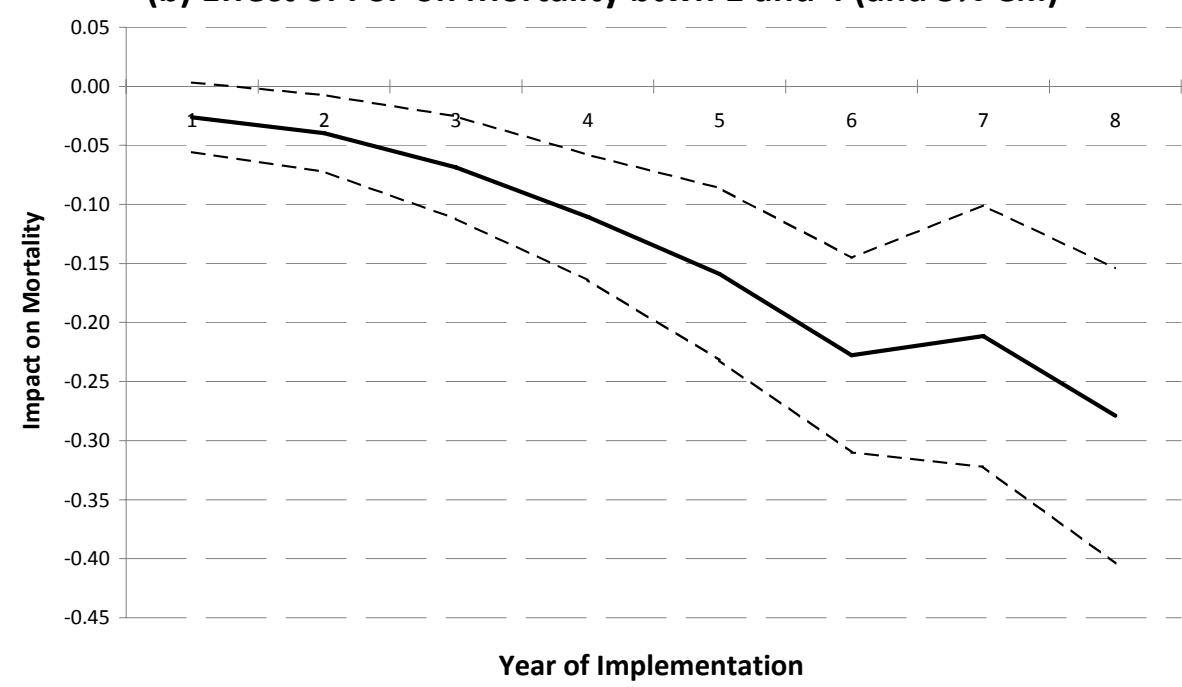

(d) Effect of PSF on Mortality above 59 (and 5\% C.I.)

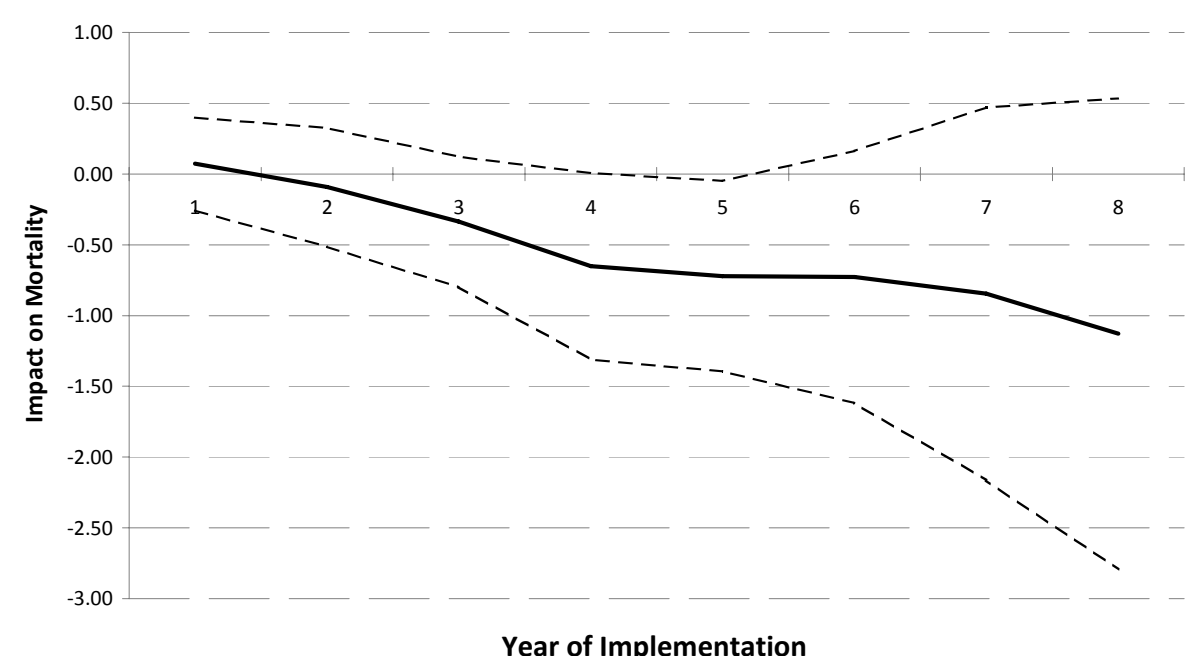

